\title{
PRÓBY CHRYSTIANIZACJI LITWY W LATACH 1248-1263
}

Zagadnienie chrztu i apostazji Mendoga doczekało się już bogatej literatury. Mimo iż w zakresie tej problematyki podstawa źródłowa nie uległa znacznemu rozszerzeniu, to jednak postępujące badania nad dziejami Litwy pogańskiej pozwalają wciąż inaczej i pełniej ocenić i zrozumieć niepowodzenie pierwszej próby chrystianizacji Litwy. Ponieważ bibliografia tej problematyki jest bardzo obszerna, ograniczymy się tu do podania ważniejszych pozycji, odsyłając zarazem czytelnika do przypisów podanych w tekście.

Sprawa chrztu Litwy znalazła swoje odpowiednie odzwierciedlenie zwłaszcza w monografiach na temat pierwszego władcy Litwy - Mendoga. Wymienić tu trzeba prace J. Latkowskiego ${ }^{1}$, J. Totoraitisa ${ }^{2}$ i Z. Ivinskisa ${ }^{3}$. Należy podkreślić, że większość ustaleń polskiego historyka, opublikowanych u schyłku XIX w., zachowuje nadal swą aktualność. Próbami powołania biskupstwa litewskiego i politycznymi uwarunkowaniami tej akcji zajęli się Wł. Abraham ${ }^{4}$ i K. Chodynicki ${ }^{5}$.

Podstawowymi pracami, obejmującymi polityczne dzieje Litwy i Żmudzi XIII w., są prace S. Zajączkowskiego ${ }^{6}$ i H. Paszkiewicza ${ }^{7}$. Zagadnienia gospodarcze i społeczne, pojęte jako wstęp do wyjaśnienia genezy państwa litewskiego, podejmuje nieocenione, monumentalne studium $\mathrm{H}$. Łowmiańskiego pt. Studia nad poczatkami społeczeństwa i państwa litewskiego, t. $1-2$, Wilno $1931-1932^{8}$. Podobny charakter nosi praca ra-

* Wykaz skrótów, zastosowanych w przypisach, zamieszczono na końcu artykułu (s. $65-66)$.

1 J. La tkow ski, Mendog, [w:] Rozprawy Akademii Umiejętności. Wydział historyczno-filozoficzny, seria II t. 3 (28), Kraków 1892, s. $300-453$.

2 J. Totoraitis, Die Litauer unter dem König Mindowe bis zum Jahre 1263, Freiburg 1905. To samo dzieło w języku litewskim: J. Totoraitis, Mindaugas Lietuvos karalius, Mariampole 1932.

3 Z. I vimskis, Primasis lietuvos karalius Mindaugas, Roma 1965.

4 Wł. A braham, Powstanie organizacji Kościoła lacinskiego na Rusi, t. 1 , Lwów 1904; tenże, Polska a chrzest Litwy, [w:] Polska i Litwa w dziejowym stosunku, Warszawa-Lublin-モódź 1914, s. 3-36.

5 K. Chodynicki, Próby zaprowadzenia chrześcijaństwa na Litwie przed r. 1386, PH 18 (1914) s. 215-255.

${ }^{6}$ S. Zająckowski, Studia nad dziejami Żmudzi wieku XIII, Lwów 1925.

7 H. Paszkiewicz, Jagiellonowie a Moskwa, t. 1, Warszawa 1933.

8 Należy tu także wymienić następujące prace tegoż autora: Agresja zakonu krzyżackiego na Litwe w wiekach XII-XV, PH 45 (1954) s. 338-371; Uwagi o genezie państwa litewskiego, PH 52 (1961) s. 127-146. 
dzieckiego historyka W. T. Paszuty. Historyk ten zajmował się zwłaszcza zagadnieniami stosunków litewsko-ruskich ${ }^{9}$.

Szereg istotnych uwag na temat przyczyn nieudanego eksperymentu chrztu Litwy w XIII w. poczynili: K. Maleczyński, J. Ochmański, M. Kosman, K. Górski i J. Powierski ${ }^{10}$.

Stosunki polsko-krzyżacko-litewskie w XIII w. zostały omówione w pracach A. L. Ewalda, S. Kujota, J. Karwasińskiej, B. Włodarskiego, R. Wróblewskiego ${ }^{11}$ oraz w licznych artykułach J. Powierskiego, zawierających wiele trafnych spostrzeżeń i ustaleń, znacznie rozszerzających naszą wiedzę na ten temat ${ }^{12}$.

Niniejszy artykuł jest próbą zebrania dotychczasowych ustaleń, wzbogaconych o własne spostrzeżenia autora co do pierwszej próby chrystianizacji Litwy w okresie 1248-1263.

\section{RYWALIZACJA O TRON LITEWSKI}

Pierwsze próby chrystianizacji Litwy pojawiły się u schyłku lat czterdziestych XIII w. i były ściśle związane z politycznymi wydarzeniami tego okresu. W pierwszej połowie XIII w. na Litwie dokonał się gwałtowny proces państwowotwórczy, który w konsekwencji doprowadził do ukształtowania się tam ustroju monarchicznego. Brak scentralizowanej władzy monarchicznej daje się stwierdzić jeszcze w r. 1219. Wtedy to spotykamy się już jednak z zalążkiem systemu państwowego w postaci

9 W. T. Paszuto, Obrazowanie litowskogo gosudarstwa, Moskwa 1959 (to samo dzieło $\mathrm{z}$ pewnymi zmianami w jezzyku litewskim: W. T. Pas z u to, Lietuvos valstybes susidarymos, Vilnius 1971); tenże, Oczerki po istorii galicko-wołynskoj Rusi, Moskwa 1950; tenże, Geroiczeskaja bor'ba russkogo naroda za niezawisimost', [w:] Istoria SSSR, Moskwa 1958, nr 6 (do końca XIII w.).

$10 \mathrm{~K}$. M a le c zyński, Sprawa chrztu $i$ apostazji Mendoga w świetle krytyki dokumentów, [w:] Pamiętnik VI Powszechnego Zjazdu Historyków Polskich, t. 1, Lwów 1935, s. 559-561; J. Ochmański, Przyczyny opóźnionej chrystianizacji Litwy, KH 78 (1971); M. Kosman, Pogaństwo, chrześcijaństwo i synkretyzm na Litwie $w$ dobie przedreformacyjnej, KMW 1/115 (1972) s. 109-122; tenże, Drogi zaniku pogaństwa u Bałtów, Wrocław 1976; tenże, Zmierzch Perkuna czyli ostatni poganie nad Battykiem, Warszawa 1981; K. Górski, Problemy chrystianizacji $w$ Prusach, Inflantach i na Litwie, KMW 26 (1982) s. 151-168; J. P owierski, Zanik pogaństwa $i$ postępy chrystianizacji u Battów, KMW (1976) s. 553-559.

11 A. L. Ewald, Die Eroberung Preussens durch die Deutschen, Bd. 1-4, Halle 1872-1886; S. Ku jot, Dzieje Prus Królewskich, cz. 1, t. 1, RTNT 20-21 (1913-1914); J. K a r wa s ińska, Sqsiedztwo kujawsko-krzyżackie 1235-1343, Warszawa 1927; H. Paszkiewicz, $\quad$ z życia politycznego Mazowsza w XIII w., [w:] Księga ku czci Oskara Haleckiego, Warszawa 1935, s. 203-228; B. Wło darski, Rywalizacja o ziemie pruskie $w$ połowie XIII $w$., RTNT 61 (1958); tenże, Polska i Ruś (1194-1340), Warszawa 1966; tenże, Problem jaćwiński $w$ stosunkach polsko-ruskich, ZH 24 (1959) s. 7-35; R. W r óblew ski, Problem jaćwieski w polityce Bolestawa Wstydliwego w latach 1248-1264, „Zeszyty Naukowe Uniwersytetu Łódzkiego", Ser. I, Nauki Hum.-Społ. R. 72, 1972.

12 J. P owierski, Dobra ostrowicko-golubskie biskupstwa włocławskiego na tle stosunków polsko-krzyżackich $w$ latach 1235-1308, Gdańsk 1977; tenże, Kazimierz kujawski a poczqtki rywalizacji o ziemie zachodniobaltyckie, ZK 6 (1981) s. 5-45; tenże, Rola Jaćwieży $w$ walce ludów battyjskich $z$ agresjq krzyżackq, 
grupy „starszych" kunigasów-książąt ${ }^{13}$. Swiadczy to o wytworzeniu się stałej formy organizacyjnej, reprezentującej na zewnątrz wszystkie ziemie Auksztoty i Żmudzi, przekraczającej swym charakterem ciasne partykularyzmy plemienne $\mathrm{i}$ terytorialne ${ }^{14}$. Było to zjawisko wyjątkowe wśród ludów bałtyjskich, jeżeli zważy się, że Prusowie nawet w obliczu zagrożenia zewnętrznego i stopniowego podboju ich obszaru etnicznego nie potrafili stworzyć ponadplemiennej organizacji, kierującej przynajmniej walką $z$ wrogiem zewnętrznym. Brak organizacji państwowej w połączeniu z silnymi partykularyzmami, nie tylko plemiennymi, lecz także poszczególnych włości (lauksów), zadecydowały o losie tego ludu ${ }^{15}$. Z podobnym zjawiskiem spotykamy się w Inflantach, gdzie z kolei tamtejsze plemiona Łotyszów, Liwów i Kurów stopniowo ulegały podbojowi niemieckiemu ${ }^{16}$.

Odmienne losy Litwinów tłumaczy się w nauce stosunkowo znacznym potencjałem gospodarczo-militarnym tego ludu ${ }^{17}$. Od schyłku XII w. wraz z postępującym rozdrobnieniem feudalnym na Rusi i wiążącymi się $z$ tym procesem walkami między przedstawicielami rozrodzonej dynastii Rurykowiczów, Litwini coraz częściej wykorzystywani byli jako siła wojskowa w międzydzielnicowych waśniach. Sami tėz często w charakterze rabusiów docierali do różnych bogatych miast ruskich, dając się im dotkliwie we znaki, zwłaszcza bogatym republikom - nowogrodzkiej i pskowskiej ${ }^{18}$.

Jednakże około r. 1240 charakter wypraw litewskich uległ pewnej zmianie. Motywy rabunkowe tych ,ekspedycji” zostały zdominowane

RB 14 (1981-1982) s. 87-116; tenże, Swiętopetk gdański $i$ Kazimierz kujawsko-tęczycki $w$ rywalizacji $z$ Zakonem Krzyżackim o ziemie battyjskie $w$ latach 1250-połowa 1252, „Rocznik Gdański” 41 (1981) s. 37-88; tenże, Polityka battyjska ksiażat polskich $w$ połowie XIII $w$. (koncesje Innocentego IV), KH 87 (1980-1981) s. 311-334; tenże, Sprawa Prus i Jaćwieży w polityce Zakonu Krzyżackiego i ksiażąt polskich $w$ okresie po ugodzie wlockawskiej z 4 VIII 1257 r., KMW 3/145 (1979) s. 255-278; tenże, Ksiqżęta polscy $i$ Zakon Krzyżacki a problem battyjski $w$ okresie od schylku 1258 do połowy 1260, KMW 4/146 (1979) s. 367-390; tenże, Wybuch II powstania pruskiego a stosunki między Zakonem Krzyżackim i ksiażętami polskimi (1260-1261), KMW 24 (1980-1981) $5.303-326$; tenże, Stanowisko polityczne ksiażat polskich wobec ludów bałtyjskich $i$ Zakonu Krzyżackiego $w$ okresie nasilenia najazdów litewskich, „Acta Baltico-Slavica” 15 (1983) s. 7-53. Już po addaniu do druku niniejsizego artykułu ukazała się jeszcze jedna praca J. Powierskiego: Ksiażę kujawski $i$ tęczycki Kazimierz a Zakon krzyżacki w latach 1248-1249, ZK 7 (1985). Autor ten zmodyfikował tu pewne swoje wcześniejsze poglądy, zwłaszcza co do akcji misyjnej abpa Alberta w Jaćwieży.

18 Ipat'ewskaja letopis, [w:] PSRL II $735 \mathrm{n}$.

$14 \mathrm{H}$. Łowmiański, Uwagi o genezie państwa litewskiego, PH 52 (1961) s. 143 .

1 Por. K. Górski, Zakon krzyżacki a powstanie państwa pruskiego, Wroclaw 1977 , s. $15-21$.

16 Tamże, s. $31-37$.

$17 \mathrm{H}$. Eow miański, Studia nad poczqtkami spoleczeństwa $i$ państwa litewskiego, t. 2, Wilno 1932, s. 279-281. Dużą rolę odegrało także położenie geograficzne Litwy $w$ głębi lądu w oddaleniu od silnych ośrodków politycznych.

18 Regesta Lithuaniae, $\mathrm{nr} 35-39,47,56,63,64,69,82,91,108,109,124,128,135$, $153,154,162,166,169,178,180,181,182,186,187$. 
przez cele polityczno-zaborcze, zmierzające do stałego podporządkowania Litwie księstw ruskich. Po raz pierwszy usadowili się Litwini w Smoleńsku w r. $1239^{19}$. Zniszczenie i uzależnienie Rusi przez Tatarów działało na ich korzyść ${ }^{20}$.

Zmieniła się także geografia tych najazdów. Celem ich coraz rzadziej stają się tereny Wielkiego Nowogrodu, obfitujące w pożądania godne łupy; one zaś przestają już odgrywać rolę decydującą, aczkolwiek trudno mówić jeszcze o ich całkowitym wyeliminowaniu. Wobec słabego rozwarstwienia społecznego, łupy stanowiły jeszcze długo jedyną możliwość zdobycia dominującej pozycji społecznej, gdyż system eksploatacji poddanej ludności dopiero się kształtował. Stałe zabory na Rusi spowodowały bowiem ważkie przeobrażenia wewnętrzne na Litwie. Na Rusi istniał już od kilku wieków system organizacji państwowej z odpowiednim aparatem fiskalnym. Daniny, dotąd uiszczane Rurykowiczom przez ludność ruską, zaczęły obecnie płynąc do kies wodzów litewskich, wśród których z czasem zrodziło się pragnienie przeniesienia tych wzorów na Litwę właściwą ${ }^{21}$. Jednocześnie należy podkreślić, że rządy litewskie nie były dotkliwe dla Rusinów. Wręcz przeciwnie, książęta litewscy szybko wrastali w miejscową kulturę ruską, utożsamiając się z miejscowymi interesami, broniąc jednocześnie mieszkańców w opanowanych przez nich księstwach przed Tatarami oraz przed roszczeniami innych Rurykowiczów ${ }^{22} \cdot$ W wytworzonej sytuacji konfrontacja dwóch systemów - plemiennego i monarchicznego, stawała się nieunikniona.

$\mathrm{W}$ toku wypraw łupieżczych wzrosła znacznie rola drużyn, a zwłaszcza ich wodzów. Cieszyli się oni wielkim autorytetem nie tylko w swych lokalnych społecznościach, lecz także wśród członków innych związków terytorialnych. Drużyna łupieżcza nosiła bowiem charakter ponadplemienny i ponadrodowy. Wybitnym dowódcom drużyn powierzano odpowiedzialne funkcje $\mathrm{w}$ ramach plemienia (np. naczelników plemiennych). W ten sposób ukształtowała się przewaga, znaczenie i wpływ pewnych rodów litewskich. Wśród nich wybitne miejsce zajęli potomkowie legendarnego Ryngolda, protoplasty rodu, do którego należeli Dowsprunk i Mendog ${ }^{23}$. Ci pojawili się po raz pierwszy w r. 1219 wśród "starszych kniaziów", zawierających układ z Romanowiczami ${ }^{24}$. Pozycja tego rodu po r. 1219 znacznie wzrosła. Na czoło wysunął się zwłaszcza Dowsprunk, którego

19 Eawrent'ewskaja letopis, [w:] PSRL I 469; por. H. モo ow mianski, Studia..., t. 2, s. 271; tenże, Uwagi o genezie..., s. 144.

${ }^{20}$ W. T. Paszut o, Obrazowanie..., s. 375.

21 H. É ow iańs ki, Studia..., t. 2, s. 350.

22 Tamże; tenże, Uwagi o genezie..., s. 144.

23 Źródła wspóliczesne nie przechowały imienia ojca Mendoga. Przypuszcza się, że brzmiało ono Ryngold: - zob. M. Str y jk ow s ki, Kronika Polska, Litewska, Zmudzka i, wszystkiej Rusi, t. 1, Warszawa 1846, s. 251-253.

24 PSRL II 735 
córka została poślubiona przez Daniela Romanowicza ${ }^{25}$. Kunigas ten w bliżej nieznanych okolicznościach zszedł z widowni politycznej, pozostawiając dwóch synów - Towtywiła i Edywida. Miejsce Dowsprunka zajął natomiast brat jego Mendog (Mindaugas), prawdopodobnie opiekun nieletnich bratanków ${ }^{26}$.

Przewaga ekonomiczna Litwy centralnej i zagarnięcie przez Mendoga rozwiniętych ekonomicznie ziem ruskich dopomogły mu do zjednoczenia Litwy, a także podporządkowania sobie części ziem jaćwięskich ${ }^{27}$. Na froncie inflanckim usiłował natomiast Mendog przeciwstawić się rozwojowi państwa biskupio-zakonnego poprzez militarne wspomaganie Żmudzi, bezpośrednio zagrożonej po podboju Kuronii ${ }^{28}$. Żmudź w początkach XIII w. przechodzi także pewien ferment państwowotwórczy, aczkolwiek mniej dynamiczny niż na Litwie. W r. 1219 reprezentowana była tylko przez dwóch kunigasów - Erdywiła i Wykinta ${ }^{20}$, przy czym charakter tego przedstawicielstwa trudno jest określić. W następnych latach na Żmudzi zwyciężyły jednak tendencje konserwatywno-plemienne, a jej związek z Litwą przechodził różne fazy: od ścisłej zależności i współdziałania do całkowitego separatyzmu. W tym czasie na Żmudzi zdobył sobie samodzielne stanowisko Wykint (o Erdywile nie ma żadnych danych), zwłaszcza po znakomitym zwycięstwie nad Zakonem Kawalerów Mieczowych w bitwie pod Szawlami (1236). Wykint był spokrewniony z rodem Ryngoldowiczów prawdopodobnie przez żonę, siostrę Mendoga i Dowsprunka. Był on zatem wujem Towtywiła i Edywida ${ }^{30}$.

Odnośnie do daty zjednoczenia całej Litwy i Żmudzi przez Mendoga istnieją w nauce różne stanowiska. Najdalej wstecz genezę monarchii litewskiej przesuwał H. Paszkiewicz, uważając, że instytucja wielkiego księcia istniała na Litwie już u schyłku XII w. ${ }^{31}$ Natomiast Mendogowi udało się opanować Litwę i Żmudź po r. 1236, kiedy to wykorzystawszy zwycięstwo Wykinta nad Zakonem Kawalerów Mieczowych uderzył on z zaskoczenia i podporządkował sobie Żmudź. Wykint zaś był zbyt słaby,

25 Tamże, 815. Latopis hipacki podaje, że ,sestra bie jeju [Towtywiła i Edywida] za Daniłom". H. Paszki ew ic z (Jagiellonowie..., s. 57) przyjmowal, że Daniel został zięciem Dowsprunka po umowie $1219 \mathrm{r}$. Małżeństwo to musiało mieć charakter polityczny, zatem Dowsprunk był kimś większym niż naczelnik plemienny lub dowódca jednej $\mathrm{z}$ potężniejszych drużyn litewskich czy bogaty nobil. Władza jego musiała już nosić pewne cechy władzy politycznej, może jeszcze ograniczonej, lecz liczącej się. W przeciwnym razie córka Dowsprunka nie byłaby odpowiednią partią dla Damiela Romanowicza. Jednakże w okresie tym trudno dopatrywać się na Litwie istnienia władzy wielkoksiążęcej, jak to twierdził $\mathrm{H}$. Pas zkiewicz (jw., s. $49-58$ ).

${ }_{26}$ Tamże, s. 55.

27 Por. niżej s.

${ }^{28}$ H. Paszkiewicz, jw., s. 59.

29 PSRL II 735.

57.

${ }^{30} \mathrm{~S}$. Z Za jączkowsk1, Studia..., s. $64 ;$ H. Paszkiewicz, jw., s. 55-

31 H. Paszkiewicz, jw., s. $44-49$. 
by się z nim mierzyć ${ }^{32}$. W 1245 r. Żmudź stanowiła już dla Mendoga podstawę operacyjną działań wojennych w Kuronii ${ }^{33}$. Zbliżone stanowisko zajmowali J. Latkowski i J. Totoraitis ${ }^{84}$. Odmiennie zaś widział genezę państwowości litewskiej $\mathrm{H}$. Łowmiański, który przyjmował, że Mendog zjednoczył całą Litwę dopiero w latach 1254-1258, natomiast Żmudź poddała mu się dopiero po bitwie durbeńskiej ${ }^{35}$.

Definitywne rozstrzygnięcie tego problemu jest o tyle trudne, że nie dysponujemy w tej materii mocną podstawą źródłową. Latopis hipacki, najbardziej wiarygodne źródło naszych wiadomości do dziejów wewnętrznych Litwy XIII w., ma bowiem w tym miejscu — pod r. 1252 (1248) tekst zniekształcony ${ }^{36}$. Pozwala on nam $\mathrm{z}$ całą pewnością stwierdzić tylko to, że pomiędzy Mendogiem a jego bratankami i szwagrem powstały jakieś nieporozumienia, które zakończyły się wygnaniem tych ostatnich ${ }^{37}$.

Chronologia wydarzeń podanych przez latopis nie jest pewna. J. Latkowski uważał, że fakt wygnania bratanków przez Mendoga miał miejsce w r. 1248, natomiast wyprawa na Smoleńszczyznę w latach 1239-1242. W tym czasie Dowsprunkowicze i Wykint mieli opanować Połock ${ }^{38}$. Historyk ten zatem oddzielił dwa wydarzenia, w latopisie hipackim podane łącznie. Właśnie ta duża luka czasowa stała się powodem zakwestionowania tych ustaleń przez H. Eowmiańskiego. Przyjął on, że w czasie wyprawy na Smoleńszczyznę spotkało krewnych Mendoga niepowodzenie, które stało się powodem nieporozumień po powrocie na Litwę ${ }^{39}$. H. Paszkiewicz przychylał się do ustaleń Latkowskiego, uważając, że skoro w r. 1239 Litwini stracili Smoleńsk, z pewnością posiadali już Połock i Witebsk. Zatem Smoleńsk opanowali przed 1239 r. Ponieważ źródła nie donoszą o żadnej wyprawie litewskiej na Smoleńsk, stąd płynie wniosek, że wyparcie ze Smoleńska Litwinów wiąże się z wygnaniem stamtąd Dowsprunkowiczów. Dlatego wyprawa, o której donosi latopis hipacki, musiała mieć miejsce przed tym rokiem. Bratankowie Mendoga i Wykint, wobec zdecydowanej przewagi militarnej kunigasa litewskiego, nie mieli zatem innego wyjścia, jak uległość i posłuszeństwo. Nie mogli wtedy liczyć na pomoc Daniela, gdyż ten pochłonięty był aż do $1245 \mathrm{r}$. walką o Halicz, następnie zaś ułożeniem stosunków z Tatarami ${ }^{40}$. Dopiero od roku 1246 datuje się zainte-

32 Tamże, s. 62.

8 LR S. $57-62$. $52-57$

84 J. Latkowski, Mendog..., s. 323; J. Totoraitis, Die Litauer..., s.

35 H. モ́ w miański, Studia..., t. 2, s. 346.

$86 \mathrm{H}$. Paszki ewicz, jw. s. 62 (p. 1).

87 PSRL II 815.

$88 \mathrm{~J}$. Latk o w ski, jw., s. $327-328,335$.

30 H. Łowmiański, Studia..., t. 2 s. $333-334$. 237.

$40 \mathrm{H}$. Paszkiewicz, jw., s. 62; W. T. Paszuto, Oczerki.., s. 234- 
resowanie Rusi Halicko-Włodzimierskiej kwestią bałtyjską, a konkretnie jaćwięską.

W tym okresie Litwa zaangażowana była na wielu frontach. W $1243 / 4$ włączyła się w powstanie pruskie ${ }^{41}$, w 1245 r. walczyła w Kuronii ${ }^{42}$, a jednocześnie Mendog wysłał pod Jarosław posiłki na pomoc Danielowi ${ }^{43}$. Często też najeżdżali Litwini Ruś północną, uzależnioną od Tatarów. Ponieważ w tym czasie nie słyszymy o żadnej wyprawie litewskiej na Ruś Halicko-Wołyńską, natomiast słychać o walkach Rusinów Daniela $\mathrm{z}$ Jaćwięgami ${ }^{44}$ skłóconymi wtedy $\mathrm{z}$ Mendogiem, musimy przyjąć, że stosunki litewsko-ruskie w latach $1247 / 8$ układały się zupełnie poprawnie. Nie wykluczone jest nawet, że Litwini wspierali Romanowiczów w walce z Jaćwięgami.

Zaangażowanie Mendoga na całym prawie froncie bałtyckim wskazuje, że musiały powstać wtedy jakieś plany zjednoczenia pod egidą Litwy wszystkich plemion bałtyjskich. Plany te napotkały zapewne przeciwdziałanie sił konserwatywno-plemiennych, zwłaszcza wśród Jaćwieży, aspirującej także do zwierzchnictwa nad częścią ludów bałtyjskich. Osłabienie siły militarnej tego plemienia leżało zatem $w$ interesie Litwy, ale nie oddanie wszystkich ziem jaćwięskich Rusi. Na tym tle mogły powstać nieporozumienia litewsko-ruskie.

Tymczasem w głębi Litwy skonsolidowały się siły wrogie Mendogowi. Naturalnie na czele opozycji stanęli Dowsprunkowicze i Wykint żmudzki, pozostający dotąd w cieniu władcy litewskiego. Zapiska latopisu hipackiego nie pozwala nam stwierdzić, czy oponenci Mendoga uciekli z Litwy na dwór Daniela. Wprawdzie kronikarz stwierdza, że skutkiem ich wygnania było ,pojmanie całej ziemi litewskiej”, ale nie znaczy to, by musieli oni uciekać z Litwy. W momencie zatargu nie było oponentów w otoczeniu Mendoga. Musiał on wysyłać przeciw nim wojsko. Gdzież zatem oni byli? Gdyby przyjąć, że około 1239 r. usadowili się za zgodą Mendoga w Połocku i Witebsku, nic nie stoi na przeszkodzie uważać, że właśnie stamtąd zbiegli na dwór Daniela. W przeciwnym wypadku nie byłoby w ogóle sensu wysyłania ich na Ruś. Przecież Mendog mógł się z nimi rozprawić od razu, skoro potrafił ich wygnać z ojcowizny i zmusić do szukania rekompensaty na Rusi. Usadowienie się wygnańców w księstwach ruskich, zapewniających stałe dochody, mogło ich włączyć do rozgrywek międzynarodowych ${ }^{45}$. W każdym razie Mendog wysłał przeciw nim swe wojsko, oni zaś natychmiast zbiegli na dwór Daniela ${ }^{46}$. Wtedy dopiero mógł Mendog zagarnąć całe mienie Dowsprunkowiczów na Litwie, a na

\footnotetext{
41 J. Pow ierski, Rola Jaćwieży..., s. 93-94.

42 LP $57-62$.

43 PSRL II 801, 805.

44 Gustinskaja Letopis, [w:] PSRL t. 2 (1843) s. 341.

45 H. P a szki e wi c z, jw., s. 190.

46 PSRL II 815.
} 
Danielu się zemścić, zagarniając Ruś Czarną. Wprawdzie milczy o tym latopis, ale była to rzecz wstydliwa, poza tym, wobec przyjaznych stosunków litewsko-ruskich w latach 1245-1248, Litwa nie miałaby kiedy zaboru tego dokonać bez daleko idących konsekwencji. Dlatego wszystko wskazuje na to, że Ruś Czarna, posiadająca zresztą własnych kniaziów dostała się pod wpływy Litwy na krótko przed konsolidacją bloku antymendogowego ${ }^{47}$. Przebieg późniejszych walk między Rusinami a Mendogiem świadczy o tym, że ci pierwsi zainteresowani byli głównie tym terenem, na innych angażując się znacznie mniej. Dla Daniela zatem kwestią najważniejszą było odzyskanie wpływów na Rusi Czarnej, stanowiącej, wobec militarnego wzrostu potencjału Litwy, strategicznie istotną pozycję. Niemały wpływ na udział Romanowiczów w walkach z Mendogiem miała także kwestia jaćwięska. Osłabienie Litwy usunęłoby najważniejszego konkurenta pretendującego do zaboru ziem tego plemienia. Ruś Halicko-Włodzimierska, wzmocniona po zwycięstwie Daniela pod Jarosławiem i zatwierdzeniu go przez Tatarów, mogła podjąć ekspansywne kroki w kierunku północnym. Dlatego naczelnym celem polityki Daniela stało się osadzenie na Litwie Towtywiła, który stał się obecnie głównym pretendentem na miejsce po Mendogu. Kandydatura Towtywiła była dla Mendoga bardzo niebezpieczna, z czego zresztą zdawał on sobie sprawę. Jak słusznie wskazał H. Paszkiewicz, Towtywiła popierało wielu Litwinów. Był on bowiem synem Dowsprunka, którego pozycja na Lit-

47 PSRL II 776: (1238) „Daniło... wozwede na Kondrata Litwu Mindoga, Izjasława Nowgorodskogo". W wyprawie z 1254 r. na Jaćwięgów uczestniczą Gleb wołkowyski i Izjasław świsłocki (PSRL II 831). Spotykamy się też z księciem słonimskim Wasylem (PSRL II 884). Status Rusi Czarnej jest nam prawie nie znany. W zasadzie uważa się, że przyłączenie Rusi Czarnej do Litwy odbyło się kosztem Rusi halicko-włodzimierskiej. Nie ma jednak wyraźnych podstaw do tego rodzaju wniosku. Jak zaznaczyliśmy, Ruś Czarna posiadała własnych kniaziów, którzy oczywiście mogli pozostawać w pewnej zależności od Rusi halicko-wołyńskiej, ale nie musiała to być zależność bardzo ścisła. Latopis hipacki jeszcze pod r. 1228 podaje, że w wyprawie na Kamieniec przeciw Danielowi brały udział posiłki z Nowogródka, Turowa i Pińska (PSRL II 753). Bardzo kontrowersyjne stanowisko w tej kwestii zajmuje badacz białoruski N. I. Jermołowicz. W artykule zatytułowanym: Iz istorii Nowogródka (s serediny XI do konca XIII w.), [w:] Biełoruskija starożytnasti, Mińsk 1972, s. 343-357, stara się on dowieść, że Mendog, zmuszony do ucieczki z Litwy (!), opanował około r. 1246 Nowogródek, usuwając być może tamtejszego księcia do Swisłoczy. Dokonał tego na tej samej zasadzie, jak inni kunigasi litewscy opanowywali księstwa Rusi północnej. Po opanowaniu Nowogródka miał Mendog uczynić sobie $z$ tego księstwa podstawę terytorialną swego państwa, przyłączając Litwę do Rusi Czarnej, a nie odwrotnie. Litwę Mendoga lokalizuje on zupełnie gdzie indziej niż się to zazwyczaj przyjmuje (tenże, Gdie była letopisnaja Litwa?, [w:] Tezisy dokladow k konferencji po archeologii Biełarusi, Mińsk 1969, s. 233-238). W oparciu o dane latopisu hipackiego umieszcza on ją nad górnym Niemnem między Mińskiem a Nowogródkiem (ze wschodu na zachód) i między Mołodecznem a Lachowiczami (z północy na południe). Lokalizacja ta ma pewne cechy prawdopodobieństwa. Jednakże wiemy, że latopis hipacki używa określenia „Litwa” w dwóch znaczeniach: węższym - odnoszącym się do ziemi litewskiej, i szerszym - określającym całą Litwę. Rozróżnienie to jest bardzo istotne, a więc wywody tegoż autora wymagają jeszcze gruntownych studiów. Inne jego poglądy nie wytrzymują krytyki. 
wie była niegdyś silniejsza od pozycji Mendoga, zatem mógł on pretendować do zajęcia pozycji ojca ${ }^{48}$. Osadzenie na Litwie Towtywiła przekraczało jednak możliwości Rusi Halicko-Włodzimierskiej. Zrodziła się zatem idea wciągnięcia do koalicji antymendogowej państwa inflanckiego. Zadania tego z ramienia Daniela podjął się Wykint. Doprowadził on do włączenia się Inflant w rozgrywki polityczne na Litwie ${ }^{40}$.

W Inflantach chrztem Litwy zainteresowane były różnorakie siły, przede wszystkim zaś episkopat i duchowieństwo oraz Zakon. Mimo iż siły te dążyły do tego samego celu, były na jego tle głęboko zantagonizowane. Episkopat i duchowieństwo inflanckie pragnęło chrystianizacji Litwy dla zabezpieczenia swych posiadłości od napaści litewskich, osiągnięcia na Litwie nabytków terytorialnych, a być może włączenia jej do państwa biskupiego. Biskup ryski Mikołaj widział w Towtywile kandydata na wasala biskupiego, który otrzymałby od niego jakąś część Litwy w lenno, natomiast pozostała uległaby podziałowi między biskupstwa i Zakon. Polityki tej trzymano się podczas podboju Semigalii ${ }^{50}$. Że takie plany istniały i wobec Litwy, świadczy znakomicie poinformowany w sprawach litewskich latopis hipacki. Po przegranej sprawie Towtywiła biskup ryski i prepozyt kapituły mieli wyrażać żal z tego powodu, gdyż zdawali sobie sprawę, ,[...] bo aszcze Tew'tywił nie by izgnan Litow'skaja zemlia w ruku bie ich i kreszczenie niewole ju prijali bysza [... ${ }^{51}$. W każdym razie Towtywił nie był dla episkopatu inflanckiego kandydatem na Wielkie Księstwo (jak tego chciał H. Paszkiewicz), gdyż takiego jeszcze nie było ${ }^{52}$. Słusznie natomiast dowodził H. Łowmiański. że koncepcję królestwa litewskiego wysunął i pomógł przy jej realizacji dopiero Zakon Krzyżacki, realizując w tym względzie swój własny interes ${ }^{53}$.

Zakon inflancki, pomimo unii z r. 1237, organizacyjnie różnił się od Zakonu pruskiego. Obserwowana w nim reguła templariuszy poddawała ich bezpośednio jurysdykcji biskupiej. Zakon inflancki był lennikiem biskupa ryskiego ${ }^{54}$. Unia z Zakonem Krzyżackim tego stosunku nie przekreśliła, pomimo usilnych starań władz zakonnych o poddanie gałęzi inflanckiej bezpośrednio Stolicy Apostolskiej ${ }^{55}$. Nieuregulowanie tych spraw

48 H. P a s zki e w i c z, jw., s. $57-58$.

49 H. Eowmiański, Studia..., t. 2 s. 278-279; H. Paszkiewicz, jw., s. 67 ; W. T. Pas z u to, Obrazowanie..., s. 378.

50 Por. K. Górski, Zakon krzyżacki..., s. 33-34; H. Łow miański, Studia..., t. 2 s. 304.

51 PSRL II 817.

52 H. Paszkiewicz, jw., s. 58.

58 H.

54 K. Chodynicki, Próby..., s. 226; F. G. Bunge, Der Orden der Schwertbrüder, dessen Stiftung, Verfassung und Auflösung, Leipzig 1875, s. 46-47; F. Benninghoven, Der Orden der Schwertbrüder. Fratres Miliciae Christi de Livonia, Köln-Graz 1965, s. 54 n. Por. bullę z r. 1237 (LUB 1 nr 149). S. 317 .

55 K. Chodynicki, Próby..., s. 226; H. 乇ow miański, Studia..., t. 2

3 - Analecta Cracoviensia 
wywoływało częste zatargi między episkopatem inflanckim a Zakonem, tym zacieklejsze, że kawalerowie mieczowi po unii z krzyżakami wywalczyli sobie silniejsze stanowisko. Po klęsce pod Szawlami na Zakon spadł główny ciężar walki o odzyskanie utraconych pozycji. Posiadłości biskupie i zakonne uległy wymieszaniu, co stanowiło jeszcze jedno pole do nieustannej rywalizacji i źródło sporów ${ }^{56}$. W tym czasie powstają także plany połączenia się z gałęzią pruską Zakonu nie tylko organizacyjnie, ale i terytorialnie. Na przeszkodzie tym planom stała Żmudź oddzielająca posiadłości pruskie i inflanckie. Podbój tej ostatniej planowano w Inflantach już w r. $1232^{57}$, lecz plany te zostały przekreślone po klęsce pod Szawlami i utracie Kuronii, Semigalii i Zelonii. Poniesionych wówczas strat długo nie można było odrobić. W toku ciężkich walk udało się Zakonowi odzyskać zaledwie Kuronię, której podbój trwał do roku $1246^{58}$.

$\mathrm{W}$ tych latach pojawiają się pewne agresywne plany także $\mathrm{w}$ stosunku do Litwy. W r. 1245 na prośbę wielkiego mistrza Henryka von Hohenlohe cesarz Fryderyk II nadał jemu i Zakonowi wszystkie ziemie, które ten zdobędzie w Kuronii, Litwie i Semigalii ${ }^{50}$. Zakon inflancki po podboju Kuronii zażądał dla siebie nie $1 / 3$, jak było dotąd, ale $2 / 3$ terytoriów w tym kraju. Ostatecznie udało mu się to żądanie zrealizować kosztem dobrych stosunków z episkopatem inflanckim ${ }^{60}$. W ostateczności przyszłość należała do silniejszego, a zdecydowaną przewagę mogło dać Zakonowi w Inflantach połączenie jego posiadłości z posiadłościami Zakonu pruskiego. Cel ten determinował całą politykę Zakonu w stosunku do Litwy.

W takich okolicznościach uzyskał Towtywił poparcie Niemców ryskich ${ }^{61}$. Do antymendogowej koalicji wciągnął on także Jaćwięgów i „poł

${ }^{\text {s6 }}$ K. Chodynicki, Próby..., s. 227; H. Łowmiański, Studia..., t. 2 s. 309; F. Benninghoven, jw., s. $362 \mathrm{n}$.

57 LUB $1 \mathrm{nr} 125$; H. Eow mia ński, Studia..., t. 2 s. 307. Nie możne wykluczyé, że chodziło w tym wypadku o włości południowokurońskie. W r. 1237 legat papieski Wilhelm z Modeny, wyznaczając granice biskupstw ryskiego, semigalskiego i kurońskiego, zaliczył do diecezji semigalskiej dużą część Żmudzi i Litwy pa Niemen i Wilię (LUB $1 \mathrm{nr} 153$; por. S. Z a jączkowski, Studia..., s. 57).

${ }_{58} \mathrm{H}$. Eow miański, Studia..., t. 2 s. 311; P. J ohansen, Kurlands Bewohner zu Anfang der historischen Zeit, [w:] Baltische Lande, Bd 1, s. $266 \mathrm{n}$.

s9 LUB $1 \mathrm{nr}$ 185; Fontes historie Latviae medii aevi (Senas Latvijas vestures avoti) fasc. 2 (ed. A. S vabe), Rigae 1940, s. 263 (nr 279); H. 乇ow miański (Agresja zakonu krzyżackiego..., s. 343) twierdził, że plany te nie nosiły charakteru ogólnokrzyżackiego, gdyż Zakon pruski zajęty był w tym czasie całkowicie walką z Prusami i Swiętopełkiem pomorskim. Nie można jednak zapominać, że Litwa brała także udział w I powstaniu pruskim, działając w sojuszu ze Swiętopełkiem pomorskim (Dursburg, s. 73 n.; PrUB I $2 \mathrm{nr} 160-162$; por. J. P owierski, Rola Jaćwieży..., s. 93; tenże, Kazimierz kujawski..., s. 14, 16).

${ }_{59}$ LUB $1 \mathrm{nr}$ 185; Fontes historiae Latviae medii aevi (Senas Latvijas vestures

01 A. L. E wald (Die Eroberung..., s. 331), a także inni historycy nie łączyli wypraw landmistrza Andrzeja $z$ porozumieniem między Towtywiłem a biskupem ryskim. W związek ten powątpiewa także J. P owierski (Swiętopetk gdańsiki..., s. 47), uważając, że do takiego wniosku źródła nie upoważniają. Widział on także 
Żemoiti [...] ubiedi ja serebrom i darmi mnogimi" ${ }^{62}$. Wykint pozyskał sobie tę część Żmudzi, w której leżała jego ojcowizna i mieszkali jego rodowcy. Możliwe, że w tej części Żmudzi sprawował Wykint funkcje naczelnika plemiennego, a więc był popierany przez tamtejszych nobilów. Pozostała część Żmudzi opowiedziała się za Mendogiem ${ }^{63}$. Do udziału w koalicji starał się Daniel wciągnąć także książąt polskich, zapewne Siemowita mazowieckiego i Bolesława Wstydliwego. Polacy pomoc obiecali, ale nie dotrzymali obietnicy ${ }^{64}$.

Zbrojną akcję przeciw Mendogowi rozpoczęli Rusini, cały swój wysiłek militarny kierując na Ruś Czarną - Nowogródek, Zdzitów, Wołkowysk i Słonim. Uzyskawszy tam pewne sukcesy, pomimo iż Nowogródka nie zdobyli, wrócili do siebie ${ }^{65}$. Tymczasem Towtywił ,s połonom Daniłowym" po licznych walkach z Mendogiem udał się do Rygi, gdzie przyjęto go z wielką czcią, a następnie ochrzczono ${ }^{66}$. Duchowieństwo inflanckie i Zakon osiągnęli swój cel. Trudno przypuszczać, że popierali oni Towtywiła bezinteresownie. Zapewne kunigas litewski, podobnie jak to zrobił później Mendog, poczynił pewne obietnice w Rydze. W r. 1250 landmistrz inflancki Andrzej von Stirlant po spustoszeniu ziemi Nalsen (nalszczańskiej) wkroczył na Litwę i doszedł aż do grodu Mendoga. W tym roku najazdowi krzyżackiemu uległa także część Żmudzi wierna Mendogowi ${ }^{67}$.

Władca litewski, osaczony ze wszystkich stron, próbuje rozbić koalicję przez sojusz z najniebezpieczniejszym militarnie przeciwnikiem - Krzyżakami inflanckimi. Wysłał zatem do landmistrza inflanckiego poselstwo domagające się zabicia Towtywiła, ofiarując w zamian liczne dary i obietnice jeszcze większych $\mathrm{w}$ razie spełnienia tego życzenia ${ }^{68}$. Landmistrz Andrzej miał wówczas oświadczyć Mendogowi: ,,[... nie możeszi izbawlien

trudność w określeniu, kto obiecał pomoc Towtywiłowi: czy Krzyżacy, czy rycerstwo biskupa ryskiego. Jednakże latopis hipacki upoważnia nas do przyjęcia wniosku, że kunigasowi litewskiemu obiecali pomoc tak jedni, jak i drudzy. Oprócz zdania stwierdzającego, że chęć pomocy wykazali „bożii dworianie i piskup i w j a woi Riżskaja”, latopis zawiera także wyraźną wskazówkę, że „obieszczasza Niemci bratja iti na pomoszez Tewtywiłu”, mimo iż Wykint „brat' ju naszu mnogu pogubi". Ostatnie zdanie odnosi się w nauce do bitwy szawelskiej (por. E. B o nmel1, Russisch-livländische Cronographie, St. Petersburg 1862, Chron. 56, Comm. 70 i 82). Podobnie żmudzki kierunek wyprawy Andrzeja nie wskazuje na wrogość Krzyżaków tak wobec antymendogowej opozycji, jak i Mendoga (J. P owierski, Swiętopetk gdański..., s. 47), gdyż wiemy, że część Żmudzi była wierna Mendogowi i jako taka została zaatakowana przez Zakon (LR 75-78).

${ }^{62}$ PSRL II 816.

${ }^{68}$ S. Zajączkowski, Studia..., s. 61.

${ }^{64}$ PSRL II 815; por. niżej s.

65 PSRL II 816; por. J. La tk ow ski, jw., s. 337.

66 PSRL II 816; "Tewtywił...krszczasy bys" (LR $80-82$ ).

${ }^{67}$ LR 75-78; S. Za jączkowski, Studia..., s. $62 ;$ H. Paszkiewicz, jw., s. $67,84,92 \mathrm{n}$.

68 PSRL II 816-817; H. Paszkiewicz, jw., s. 92 n. 
byti aszcze nie poslieszi $\mathrm{k}$ papie i primieszi kreszczenia nie odolieszi wragu" " ${ }^{8}$. Słowa te świadczą o przychylnym stosunku Zakonu do osoby Mendoga, bardzo cennej i godnej wykorzystania w polityce zakonnej ${ }^{70}$. Dla Zakonu Towtywił nie przedstawiał takiej wartości jak Mendog. W wypadku zwycięstwa sprawy Towtywiła było wielu kandydatów do ewentualnych korzyści. Mendog tymczasem był osamotniony. Ewentualne poparcie dla jego osoby wiele obiecywało i wykluczało innych. Dawało także przewagę nad episkopatem. Nawrócenie Mendoga i jego chrzest byłoby tylko dziełem Krzyżaków inflanckich, a z tego faktu można było wyciągnąc nie tylko korzyści propagandowe. Wiemy, że cała polityka Krzyżaków inflanckich nakierowana była na połączenie swych posiadłości z posiadłościami Zakonu pruskiego. Posiadłości te oddzielała Żmudź. Pamiętamy także, że ziemie żmudzkie, którymi najbardziej zainteresowani byli Krzyżacy, popierały Towtywiła. Tam też wielkie wpływy posiadał wuj Dowsprunkowiczów Wykint. Zwycięstwo sprawy Towtywiła nie dałoby zatem Zakonowi żadnych nabytków terytorialnych $\mathrm{w}$ tych stronach, natomiast wzmocniłoby elementy najbardziej Zakonowi wrogie. Dlatego posunięcia przeciw Mendogowi nosiły raczej charakter dywersyjny i obliczone były, być może, na zachęcenie Mendoga do współpracy ${ }^{71}$. H. Łowmiański odrzucił możliwość istnienia po stronie krzyżackiej poważnych planów zagarnięcia Auksztoty, ponieważ cel ich polityki nie zwracał się przeciw niej i Mendogowi. Dlatego tak łatwo zrozumieć nagły zwrot, jaki nastąpił $\mathrm{w}$ stosunkach Zakonu z Litwą ${ }^{72}$.

Mendog bowiem przychylił się ku planom krzyżackim. Landmistrz Andrzej wystąpił natychmiast $\mathrm{z}$ projektem uczynienia $\mathrm{z}$ Mendoga monarchy chrześcijańskiego, zobowiązał się wspierać go przeciw nieprzyjaciołom i wystarać się u papieża o koronę ${ }^{73}$. W końcu 1250 lub z początkiem 1251 r. Mendog wraz ze swą małżonką Martą oraz dwoma młodszymi synami i popierającymi go nobilami przyjął chrzest. Jednocześnie udało się do Rygi poselstwo litewskie na czele z Parnusem, by stamtąd wraz z delegacją krzyżacką udać się do Włoch ${ }^{74}$. Wobec takiego obrotu sprawy Towtywił utracił poparcie w Rydze i udał się na Żmudź do Wykinta. Wraz z nim oraz z posiłkami Daniela i Jaćwięgami próbował Towtywił walczyć z Mendogiem, popieranym już wówczas przez posiłki krzyżackie. Doszło do walk na Żmudzi, pod grodem Wykinta - Twiremetem. Mendog, ranny $w$ nogę, wycofał się na Litwę, ale pod Twire-

60 PSRL II 817.

70 Andrzej miał oświadczyć Mendogowi: „drużbu imieju k tebe” (PSRL II 817).

71 Por. J. Powierski, Swiętopełk gdański..., s. 47.

72 H. Łow miański, Studia..., t. 2 s. 312.

73 J. Latkowski, Mendog..., s. 342 .

74 LR 81-82; Vetera Monumenta I nr 102; J. Latkowski, jw., s. 344. 
metem zginął prawdopodobnie Wykint ${ }^{75}$. Natomiast zimą 1251 Daniel halicki z posiłkami jaćwięskimi ponownie zaatakował Ruś Czarną. Spustoszeniu uległy okolice Nowogródka, ale Litwinów nie zdołano stamtąd wyprzeć. Drugiej wyprawie na czele z Wasylkiem Włodzimierskim i Romanem Daniłowiczem udało się zdobyć Grodno. W trakcie równocześnie podjętej wyprawy zdobyto pewne grody i spustoszono ziemie podległe Litwie $^{76}$. Aczkolwiek Mendog był jeszcze zbyt słaby, by przeciwdziałać tym wyprawom, to jednak było jasne, że wobec rozkładu koalicji nie było szans całkowitego rozbicia jego sił. Towtywił zaś przez pewien czas utrzymał się na Żmudzi. Dopiero gdy Wojsiełk, syn Mendoga, przekupił Żmudzinów i Jaćwięgów, został zmuszony do ucieczki na dwór Daniela, który obu Dowsprunkowiczów zabrał na wyprawę austriacką w r. $1253^{77}$.

$\mathrm{Na}$ Litwę wrócił Towtywił po pokoju chełmskim z r. $1254^{78}$. Przypuszcza się, że otrzymał on od Mendoga Połock, w którym jako kniaź poświadczony jest źródłowo dopiero $\mathrm{w}$ r. $1262^{79}$. Po śmierci Mendoga został on zamordowany $\mathrm{w}$ trakcie sporu o spadek po pierwszym królu litewskim ${ }^{80}$. Nie dane było Towtywiłowi zostać pierwszym chrześcijańskim władcą Litwy. Okoliczności polityczne sprawiły, że został nim jego wuj Mendog. Poprzez niego starano się zatem dokonać chrystianizacji jednego $\mathrm{z}$ ostatnich bastionów pogaństwa w Europie.

\section{BISKUPSTWO LITEWSKIE}

W zabiegach o powołanie organizacji kościelnej na Litwie od samego początku przewagę zdobyła sobie koncepcja krzyżacka. Krzyżacy też postarali się o wyeliminowanie $\mathrm{z}$ tej akcji swego wielkiego przeciwnika, arcybiskupa prusko-inflanckiego Alberta. Albert Suerbeer, poprzednio arcybiskup irlandzki, został mianowany arcybiskupem pruskim w r. $1246^{{ }^{81}}$. Władzy jego poddał papież biskupów w Prusach, Inflantach i Estonii, nie podlegających dotąd żadnemu arcybiskupowi ${ }^{82}$. Niewiele później otrzymał również godność legata papieskiego ${ }^{83}$. Stosunki arcybiskupa z Zakonem

75 PSRL II 817-818; J. La tk ow ski, jw., s. 347.

76 PSRL II $818 \mathrm{n}$.

77 Tamże, s. $820,822$.

78 Tamże, s. $830-831$; J. La tk ow sk i, jw., s. 371 .

79 NPL S. 83.

80 PSRL II 861.

${ }^{81}$ PrUB I nr 177; por. P. von Goetze, Albert Suerbeer, Erzbischof von Preussen, Livland und Esthland, St. Petersburg 1854; M. R o h ko hl, Albert Suerbeer, Erzbischof von Livland, Esthland und Preussen, „Zeitschrift der Gesellschaft für Schleswig-Holsteinische Geschichte" 47 (1917); K. Forstreuter, Fragen der Mission in Preussen von 1245 bis 1260, „Zeitschrift für Ostforschung” 9 (1960) H. $2-3$.

82 PrUB I nr 176; CDWarm. I nr 11.

83 PrUB I nr 180; LUB I nr 189. 
nie układały się najlepiej. Krzyżacy nie dopuścili do tego, by osiadł on w Prusach i nie uznawali go aż do r. $1250^{84}$, a właściwie do $1251^{85}$. Starali się bowiem usilnie o to, by w nowym państwie pruskim nie wytworzyła się niezależna od nich władza kościelna ${ }^{86}$. Przez długi czas Zakon uniemożliwiał arcybiskupowi przyjazd do Prus, zaś później, kiedy jako legat papieski bez porozumienia z Zakonem rozwiązał kwestię jaćwięską i aktywnie sobie w Prusach poczynał, został przez Krzyżaków wygnany. Arcybiskup ze swej strony obłożył Zakon ekskomuniką. Próby mediacji między stronami podjęte 10 stycznia 1250 r. skończyły się niepowodzeniem ${ }^{87}$. Jesienią 1250 r. Krzyżakom udało się doprowadzić w Kurii do pozbawienia Alberta godności legata papieskiego (27 września 1250 r.) ${ }^{88}$. Zatem w chwili rozpoczęcia zabiegów o chrzest Litwy w oparciu o Mendoga arcybiskup godności tej nie posiadał. Istnieją dowody na to, iż Albert zają $1 \mathrm{w}$ stosunku do sojuszu z Mendogiem stanowisko nieprzychylne. Być może, arcybiskup popierał plany episkopatu inflanckiego, który ze swej strony nie darzył Zakonu wielkimi względami ${ }^{80}$. Wiadomo jednak, że Towtywił przyjął już chrzest w Rydze, a duchowieństwo inflanckie nie było zapewne skłonne tak szybko porzucać sprawy tego neofity.

Dlatego Zakon przeprowadził sprawę w Kurii w ten sposób, by arcybiskup został całkiem na uboczu. Innocenty IV przyjął poselstwo Mendoga $\mathrm{z}$ wielką radością ${ }^{90}$. Papiestwo bowiem, wychodząc $\mathrm{z}$ założeń natury religijnej, chętniej widziało powstawanie nowych państw chrześcijańskich niż zbrojny podbój krajów pogańskich, który uznawało za zło konieczne. Dlatego chętnie udzielało swego poparcia nowo nawróconym władcom. Trudność tkwiła jednak w tym, że ludy bałtyjskie nie wytworzyły jeszcze organizacji państwowych, pozostając na etapie ustroju rodowo-plemiennego. Brak jedności politycznej i słabo ukształtowane formy ustrojowe nie sprzyjały wprowadzaniu instytucji kościelnych, przystosowanych do struktur feudalno-państwowych. Nawrócenie jednego z możnych, nawet naczelnika plemiennego, nie pociągało za sobą automatycznej chrystianizacji kraju. Jedyną drogą rozprzestrzeniania chrześcijaństwa wśród tych

${ }^{84}$ PrUB I nr 217. W sprawie datacji tej ugody zob.: J. P owierski, Świętopetk gdański..., s. $42,44$.

85 PrUB I $n$ r 240.

${ }^{86}$ K. Górski, Zakon krzyżacki..., s. 42.

87 PrUB I nr 217; K. Forstreuter, jw., s. 262 n.; J. Powierski, Swiętopetk gdański..., s. 42-47. Dnia 9 lipca 1247 r. papież powierzył arcybiskupowi Albertowi w czasową administrację biskupstwo lubeckie, ponieważ nie mógł on utrzymać się w swej prowincji ,propter malitiam habitantium" (PrUB I 2 nr 929; por. P. von Goetze, jw., s. 15 n.; J. Powierski, Kazimierz kujawski..., s. 32).

${ }_{88}$ PrUB I nr 236; J. P owierski, Swiętopełk gdański..., s. 46, 50 n. Arcybiskup już w marcu tr. popadł w konflikt $\mathrm{z}$ Zakonem.

89 J. Powierski, Kazimierz kujawski..., s. 32.

90 Vetera Monumenta I nr 102, 103; MPV III nr 67. 
ludów wydawał się zbrojny podbój, krucjata, za którą szły procesy państwowotwórcze, gwarantujące $\mathrm{z}$ kolei byt instytucjom kościelnym ${ }^{91}$.

Krzyżacy inflanccy, występujący jako rzecznicy pokojowej chrystianizacji Litwy, usiłowali wzmocnić swe stanowisko w Kurii w sporze pomiędzy nimi a arcybiskupem Albertem. Projekt swój usiłowali przeprowadzić przy pomocy biskupa chełmińskiego Heidenryka. Był on pierwszym biskupem chełmińskim (diecezja została utworzona w 1243 r.), należał do Zakonu dominikanów ${ }^{92}$. W Prusach pojawił się po raz pierwszy w r. 1245 jako legat papieski (na miejsce Wilhelma z Modeny) na Inflanty, Prusy, ziemię chełmińską, Polskę i Czechy. Godności tej nie piastował długo. W r. 1246 papież mianował legatem arcybiskupa Alberta, rozszerzając następnie jego legację na Ruś Halicko-Włodzimierską. K. Chodynicki $\mathrm{w}$ fakcie tym dopatrywał się źródeł antagonizmu pomiędzy tymi dwoma dostojnikami kościelnymi ${ }^{93}$. Kiedy w r. 1246 powstało arcybiskupstwo prusko-inflanckie, biskup chełmiński starał się nie wejść do tego związku metropolitalnego. W r. 1248 uczestniczył nawet w synodzie wrocławskim metropolii gnieźnieńskiej wraz z biskupami polskimi ${ }^{94}$. Natomiast $\mathrm{w}$ stosunku do Zakonu biskup chełmiński był na ogół nastawiony przychylnie, dwukrotnie brał go w obronę i załatwiał wiele spraw krzyżackich ${ }^{95}$. Jemu też pragnął Zakon powierzyć sprawę powołania organizacji kościelnej na Litwie i koronację Mendoga ${ }^{96}$.

Równocześnie próbowali Krzyżacy sparaliżować działania arcybiskupa Alberta. Wreszcie 24 lutego $1251 \mathrm{r}$. został on zmuszony do zawarcia układu z Zakonem, będącego $\mathrm{w}$ rezultacie jego przegraną $\mathrm{w}$ sporze $\mathrm{z}$ tym ostatnim. Na mocy układu Zakon zachował prawo wykupu wotów krucjatowych, arcybiskup zaś zobowiązał się nie przeszkadzać w głoszeniu na rzecz Krzyżaków wypraw krzyżowych, przestrzegać przywilejów Zakonu wraz $\mathrm{z}$ korzystną dla niego interpretacją postanowień Wilhelma z Modeny z r. 1243, a więc prawa Krzyżaków do 2/3 Prus i Kuronii wraz $\mathrm{z}$ dziesięcinami. Zakon przyrzekł respektować jurysdykcję arcybiskupa w całej prowincji. Arcybiskup przyrzekł także nie wyrządzać szkód Zakonowi i nie zawierać sojuszów z poganami lub chrześcijanami przeciw braciom zakonnym ${ }^{97}$. Niektóre warunki układu dotyczyły z pewnością chrystianizacji Litwy. Otóż arcybiskup zobowiązał się, że „si pagani alicuius terre

91 H. Łow miański, Studia.., t. 2 s. 285-289, 318; J. O chmański, Przyczyny opóźnionej chrystianizacji Litwy, KH 78 (1971) s. 870.

${ }_{92}$ PrUB I nr 142, 143, 144; por. K. Gór s k i, Henryk Heidenreich, pierwszy biskup chetminski, [w:] Studia nad historia dominikanów $w$ Polsce, t. 2, Warszawa 1975, s. 179-192.

${ }_{93} \mathrm{~K}$. Chodynicki, Próby..., s. 237.

${ }^{94} \mathrm{KDW}$ t. I nr 274; Wł. A brah a m, Powstanie organizacji..., s. 152.

${ }_{95} \mathrm{~K}$. Chodynicki, Próby..., s. 234.

${ }^{26}$ Por. J. P ow i e rski, Swiętopetk gdański..., s. 58.

87 PrUB I nr 240. 
[tzn. Litwę] ad fidem converti voluerint, idem Archiepiscopus cum episcopis et fratribus supradictis eos comiter et benigne suscipiet sub conditionibus tolerabilibus et honestis in quorum receptione, si copia predicti Archiepiscopi haberi non possit, fratres loco ipsius aliquem de suffraganeis eius assumant, qui cum ipsis fratribus negotium prosequatur" ${ }^{\text {8s }}$. Natomiast 3 marca $1251 \mathrm{r}$. zawarta została umowa dodatkowa, w wyniku której siedzibą arcybiskupa została Ryga. Po rezygnacji dotychczasowego biskupa ryskiego Mikołaja lub po jego śmierci diecezja ryska wraz z władztwem biskupstwa ryskiego miała przypaść arcybiskupowi ${ }^{90}$. Ugoda z 24 lutego $1251 \mathrm{r}$. została potwierdzona przez papieża 9 marca tegoż roku. Do przestrzegania jej zobowiązał papież obie strony pod groźbą ekskomuniki, upoważniając do dopilnowania tej sprawy biskupa ołomunieckiego Brunona ${ }^{100}$. Natomiast postanowienia z 3 marca zatwierdził papież 14 marca 1251 r., a ich wykonanie nakazał biskupowi ozylijskiemu ${ }^{101}$.

W ten sposób pozbyli się Krzyżacy groźnego przeciwnika z terenu Prus, a także odsunęli go od sprawy misji na Litwie. Tym, który miał przeprowadzić chrystianizację kraju wespół z braćmi Zakonu, został biskup chełmiński Heidenryk, uznany przez ugodę za sufragana arcybiskupa prusko-inflanckiego pomimo tego, iż oficjalnie biskupstwo chełmińskie włączono do metropolii ryskiej dopiero w $1255^{102}$. Możliwe, że stwierdzenie to było ustępstwem krzyżackim wobec arcybiskupa. W każdym razie możemy z dużym prawdopodobieństwem przypuszczać, że już w chwili ugody (24 luty) bracia zakonni byli zdecydowani na osobę biskupa chełmińskiego.

Jako organizator Kościoła litewskiego pojawił się Heidenryk w lipcu $1251 \mathrm{r}$. Innocenty IV, chcąc zapobiec ewentualnym nadużyciom w trakcie planowanej misji, nakazał biskupowi chełmińskiemu, aby dziesięcinę kościelną z królestwa litewskiego pobierał w sposób umiarkowany ${ }^{103}$. Papież dobrze zdawał sobie sprawę z trudności, na jakie natkną się w przyszłości biskup, prałaci i duchowieństwo pośród neofitów, żyjących do tej pory „solita lege naturae”. Nadużycia na tym polu były zjawiskiem nader częstym w trakcie misji bałtyckich ${ }^{104}$.

Dwa dni później, 17 lipca 1251 r., Innocenty IV przyjął pod opiekę św.

${ }_{98}$ Tamże. J. P ow ie rski (Swiętopetk gdański..., s. 58) interpretuje ten fragment $w$ ten sposób, że Zakon miał zająć się sprawą chrystianizacji pogan tylko wtedy, gdyby arcybiskupowi zabrakło odpowiedniego wojska dla podboju ich ziem. Tymczasem ugoda mówi raczej o chrześcijanach, którzy dobrowolnie chcą się ochrzcić: ,si pagani alicuius terre ad fidem converti voluerint"; zatem slowo „,copia” należałoby raczej tłumaczyć w sensie: możność, moc. Krzyżacy dobrze wiedzieli, że arcybiskup tej możności i środków nie będzie miał.

${ }_{99}$ LUB I $\mathrm{nr}$ 219; PrUB I nr 241.

100 PrUB I mr 243, 244.

101 LUB I nr 222, 223; PrUB I nr 245.

102 PrUB I nr 307; CDWarm I nr 32.

103 UC I nr 26; Vetera Monumenta I nr 101.

$104 \mathrm{H}$. Łow miański, Studia..., t. 2 s. 296-299. 
Piotra królestwo litewskie, a wraz z nim Mendoga, jego rodzinę oraz wszystkie ziemie, które zdobył i zdobędzie w przyszłości na niewiernych ${ }^{105}$. W tym też dniu nakazał papież biskupowi chełmińskiemu, by wybrał i wyświęcił biskupa dla Litwy ${ }^{108}$. Organizację biskupstwa uzależnił papież od wybudowania i uposażenia katedry biskupiej. Natomiast od razu określono przynależność organizacyjną nowego biskupstwa. Nie miało ono wejść w skład metropolii ryskiej, lecz podlegać „,soli Romano Pontifici”. Przyszły biskup litewski miał złożyć przysięgę wierności papieżowi na ręce biskupa chełmińskiego. Nie ulega wątpliwości, że to głównie Krzyżacy starali się o egzempcję diecezji litewskiej. Ponieważ Mendog wszystkie sprawy kościelne załatwiał za ich pośrednictwem i był właściwie na nich zdany, mogli Krzyżacy wywierać odpowiedni wpływ na polityczne i kościelne sprawy Litwy, izolując ją zarazem od niepożądanych ingerencji metropoli prusko-inflanckiej ${ }^{107}$. Episkopat inflancki zapewne dobrze to rozumiał i dlatego nie był zbyt chętny okazywać poparcia Mendogowi. W tej sytuacji papież był zmuszony skierować do biskupów: kurońskiego i ozylijskiego, specjalną bullę zakazującą stawiania jakichkolwiek przeszkód królowi litewskiemu ${ }^{108}$.

Pomimo - wydawałoby się - sprzyjających okoliczności, nie doszło w r. 1251 ani do koronacji Mendoga, ani do organizacji Kościoła na Litwie. Wielokrotnie zastanawiano się nad przyczynami tego stanu rzeczy. Jako jeden $\mathrm{z}$ powodów podawano przeszkody czynione ze strony arcybiskupa i biskupów inflanckich. Że takowe istniały, to nie ulega wątpliwości ${ }^{109}$. K. Chodynicki uważał, że ,pieczę nad nowo nawróconym księciem chciało rozciągnąc każde z biskupstw nadbałtyckich", dlatego papież uwzględnił te dążenia, polecając króla litewskiego opiece biskupów: kurońskiego, ryskiego, dorpackiego, ozylijskiego oraz Zakonu niemieckiego ${ }^{110}$. Wydaje się jednak, że sprawy miały się trochę inaczej. Otóż papież zdawał sobie sprawę, że chrystianizacja Litwy nie jest możliwa bez współdziałania biskupów inflanckich. Dlatego wprost nakazywał im, aby , ,[...] eidem Regi super conversione vel subiugatione infidelium huiusmodi obtinenda, necnon super invasoribus seu quibuscumque terre sue molestatoribus compescendis spirituali et temporali districtione una cum dilectis filiis [...] Magistro et fratribus hospitalis sancte Marie Theutonicorum in Livonia manentium, sicut efficacius poteritis, assistatis" ${ }^{111}$.

105 MPV III nr 67; Vetera Monumenta I nr 102.

106 UC I nr 28; Vetera Monumenta I nr 105.

107 H. Łow miański, Studia..., t. 2 s. $318-319$.

108 LUB I nr 225; Vetera Monumenta I nr 103.

${ }_{109}$ H. Łow miański, Studia..., t. 2 s. 318 ; J. Powierski, Swiętopełk gdański..., s. 60 .

110 K. Chodynicki, Próby..., s. 230; LUB I nr 226; Vetera Monumenta I nr 106.

111 Vetera Monumenta I nr 106. 
H. Łowmiański uważał, że Mendog w tym czasie nie był jeszcze w stanie spełnić wymogów stawianych przez papieża (budowa katedry i zapewnienie jej dochodów) ${ }^{112}$. Władza króla litewskiego była jeszcze mocno ograniczona. Silne były tendencje decentralistyczne. Słabe formy ustrojowe przejawiały się $\mathrm{w}$ tym, że $\mathrm{w}$ samej Litwie istniał cały szereg kunigasów posiadających większe majątki, lecz ich władza nie nosiła charakteru monarszego ${ }^{113}$. Byli to panowie tworzący dopiero zawiązek feudałów, rekrutujący się $\mathrm{z}$ naczelników licznych i zamożnych rodów chłopskich. W czasie wojny przekazywano im dowództwo, mieli prawo zwoływania pospolitego ruszenia, nakazywali budowę umocnień. Posiadali także niewielkie drużyny ${ }^{114}$. Nadal funkcjonował wiec jako instytucja decydująca o ważniejszych sprawach. Wprawdzie Mendog, jako najpotężniejszy kunigas, mógł z pewnością wywierać decydujący wpływ na jego przebieg i rezultaty, ale niekoniecznie we wszystkich sprawach. Decyzja o przyjęciu chrztu winna była zapaść na wiecu ogólnoplemiennym, by była skuteczna. Należy jednak wątpić, czy na takim zgromadzeniu w ogóle by zapadła ${ }^{115}$. Chrzest Mendoga, mimo że dotyczył najpotężniejszego kunigasa i wodza, nie mógł być decydujący, jeśli chodzi o całą Litwę. Dlatego Mendog w r. 1251 ani nie zdołał zbudować i uposażyć katedry ${ }^{118}$, ani nawet się koronować, choć Stolica Apostolska już uznała go za króla i wyraziła zgodę na jego koronację. Aby uporać się z przeciwnikami wewnętrznymi, musiał Mendog najpierw pokonać wrogów zewnętrznych. Zakon stał już po jego stronie, arcybiskup prusko-inflancki był unieszkodliwiony. Ale do końca r. 1252 (lub do początku 1253) utrzymywał się na Żmudzi Towtywił, popierany przez Daniela, Jaćwięgów i Żmudzinów. A Towtywił był przecież kunigasem auksztockim i z pewnością nie brakowało mu zwolenników w samej Auksztocie, czekających tylko na porażkę Mendoga.

Prawdopodobnie w pierwszych miesiącach 1252 r. na Żmudź i Kuronię wyprawil się mistrz krajowy pruski Eberhard von Sayn, jako namiestnik wielkiego mistrza na Inflanty i Kuronię. Na terenie Kuronii zbudował i obsadził załogą gród w Kłajpedzie. Zamek ten miał uniemożliwiać kontakty między Żmudzinami i Sambami ${ }^{117}$. Dla gałęzi pruskiej Zakonu był to wstęp do podboju Sambii, ale — być może - akcja ta uzgodniona była także z gałęzią inflancką, a celem jej było zabezpieczenie Litwy przed najazdem żmudzkim w czasie, gdy miały się tam dokonać ważne wydarzenia polityczne. Chronologia tych wydarzeń nie jest pewna. Wiemy tylko, że wyprawę, mającą na celu budowę Kłajpedy, poprzedziła akcja

112 H. E ow miański, Studia..., t. 2 s. 342.

113 Tamże, s. $167-173$.

114 Tamże, s. $184-190$.

$115 \mathrm{~K}$. Górski, Zakon krzyżacki..., s. 19-20.

116 H. Łow miański, Studia..., t. 2 s. 342.

117 LR s. 83; J. P ow ierski, Swiętopetk gdański..., s. 77 (tam też literatura); por. też S. Zają c zkowski, Studia..., s. $65,79,85-86$. 
Krzyżaków przeciw Żmudzi, w trakcie której Żmudź została spustoszona ${ }^{118}$.

W tym czasie dotarł do Inflant biskup chełmiński Heidenryk, który już przed 1 października 1251 r. opuścił Prusy ${ }^{119}$. Po przybyciu do Rygi, jeszcze przed pojawieniem się tam Eberharda von Sayn, z orszakiem landmistrza Andrzeja von Stirlant udał się na Litwę, by wykonać powierzone mu przez papieża zadanie. Tam jego działalność zbiega się chronologicznie z akcją Eberharda von Sayn przeciw Żmudzi, a więc miała miejsce gdzieś na początku $1252 \mathrm{r}$.

Wtedy to biskup chełmiński dokonał koronacji Mendoga ${ }^{120}$. Według późniejszej tradycji, miejscem koronacji był Nowogródek położony na Rusi Czarnej ${ }^{121}$. H. Paszkiewicz uważał, że był to teren dla króla bezpieczny, od dawna chrześcijański i oddalony od ośrodków pogańskich, wrogo wobec chrześcijaństwa nastawionych ${ }^{122}$. Poprzez koronację $\mathrm{w}$ tym miejscu mógł Mendog także podkreślić wobec katolickiego świata swe prawa od tego kraju, będącego przedmiotem sporu z Rusią Halicko-Włodzimierską. J. Powierski wyraził przypuszczenie, że w czasie ruskich wypraw przeciw Litwie zimą 1251/1252 r. Mendog przyjmował gości i przygotowywał koronację, odwetowa zaś wyprawa syna Mendoga na Turyjsk wyruszyła właśnie wtedy, gdy król litewski czuł się bezpiecznie wobec bawiących $\mathrm{u}$ niego sił krzyżackich ${ }^{123}$. Podczas ceremonii koronacyjnej obecni byli, prócz biskupa chełmińskiego Heidenryka i landmistrza Andrzeja, także kapłan krzyżacki Chrystian, późniejszy biskup litewski, oraz prawdopodobnie biskup jaćwięski Henryk ${ }^{124}$ i liczni goście zakonni ${ }^{125}$.

Po ceremonii koronacyjnej Heidenryk i landmistrz Andrzej pozostawili władcy litewskiemu posiłki krzyżackie, a także duchownych dla przeprowadzenia misji chrystianizacyjnej, po czym powrócili do Inflant. Prawdopodobnie pod koniec tego roku Andrzej ustąpił ze swego stanowiska wobec bawiącego w Inflantach Eberharda von Sayn ${ }^{126}$. Przed wyjazdem

118 LR s. 83.

119 J. P ow ierski, Swiętopełk gdański..., s. 78.

120 Tamże, s. 82. Autor trafnie przesuwa datę koronacji Mendoga na rok 1252.

121 M. Stry jkow ski, Kronika Polska..., t. 1 s. 289; PSRL t. 2 s. 342.

122 H. Paszkiewicz, jw., s. $80-81$.

128 J. P owierski, Swiętopelk gdański..., s. 82; PSRL II 819.

124 K. Górski, Descriptiones terrarum, s. 9, 11-12. Negatywnie w sprawie udziału tego ostatniego wypowiedział się J. Ochmański (Nieznany autor „Opisu Krajów” z drugiej połowy XIII wieku i jego wiadomości o Bałtach, „Lituano-slavica Posnaniensia. Studia Historica” I, s. 111-113).

${ }_{125}$ LR s. 82 n.; LUB I nr 243; PrUB I 2 nr 39; por. J. L atk ow ski, Mendog..., s. 251. Ceremonię koronacyjną usiłował zrekonstruować Z. I vinskis (Mindaugas und seine Krone, ,Zeitschrift für Ostforschung" 3, 1954, H. 3 s. 360-386).

${ }^{126}$ LR s. 82 n. W sprawie rezygnacji landmistrza Andrzeja zob. J. P o w i e r s k i, Swiętopelk gdański..., s. $78-80$. 
do Niemiec Andrzej miał odwiedzić swego przyjaciela Mendoga i zastać tam braci zakonnych w zupełnym bezpieczeństwie ${ }^{127}$.

Pod koniec tego roku sytuacja Mendoga znacznie się poprawiła. Mimo oporu Żmudzinów i Sambów, którzy otoczyli Kłajpedę twierdzami, udało się Krzyżakom zbudować zamek ${ }^{128}$. Wkrótce nowy landmistrz inflancki Anno von Sangerhausen przedsięwziął odwetową wyprawę do Sambii ${ }^{120}$. Żmudź była poważnie zagrożona. Dlatego tamtejsi kunigasi byli bardziej skłonni do porozumienia z Mendogiem. Toteż królowi litewskiemu udało się przekupić ich oraz Jaćwięgów ${ }^{180}$. Antymendogowa koalicja przestała istnieć. Towtywił utraciwszy poparcie na Żmudzi zbiegł na dwór Daniela. Ruś Halicko-Włodzimierska też w tym czasie nie mogła poświęcić większej uwagi Litwie. Groził jej bowiem nowy najazd tatarski ${ }^{181}$. Później Daniel $\mathrm{w}$ sojuszu z królem węgierskim zaangażował się $\mathrm{w}$ walkę o spuściznę po Babenbergach. Na wyprawę austriacką w czerwcu 1253 r. zabrał ze sobą dwóch nieszczęsnych Dowsprunkowiczów - Towtywiła i Edywida ${ }^{132}$.

Z tego okresu pochodzą bulle papieskie dowodzące, że sprawa organizacji kościelnej na Litwie stała się znowu aktualna. Prawdopodobnie Kuria posiadała już informacje na temat działalności biskupa Heidenryka. Tym razem sprawą chrystianizacji Litwy miał zając się arcybiskup Albert. Ta zmiana związana była z okresową niełaską, w jaką popadł Zakon w tym czasie na tle sporów między papiestwem a cesarstwem ${ }^{183}$. 24 czerwca $1253 \mathrm{r}$. Innocenty IV polecił Albertowi wybrać i konsekrować biskupa dla Litwy. W bulli tej papież podkreślał ponowną gotowość w tym kierunku króla Litwy, który ,ecclesiam cathedralem in expensis suis de novo erigere sit paratus" ${ }^{184}$.

Są poszlaki pozwalające przypuszczać, że episkopat inflancki był doskonale poinformowany o przebiegu tych spraw. Najbardziej zainteresowany był tu biskup kuroński Henryk. W kwietniu 1253 r. on i Eberhard von Sayn dokonali podziału Kuronii, do której zaliczyli też żmudzką ziemię Ceclis oraz nadmorskie włości Duvzare, Megowe i Pilsaten, zamieszkałe przez Łotyszów i Żmudzinów ${ }^{135}$. Ziemie te były zdaje się, w po-

127 LR s. 83.

128 LUB I nr 245; por. J. P owierski, Swiętopekk gdański..., s. 80.

129 LR s. $87 \mathrm{n}$.

180 PSRL II 820.

181 W. T. P a s z u t o, Oczerki..., s. 272, 282.

132 B. Włodarski, Polska i Ruś..., s. 142-143; PSRL II 822.

183 Abp Albert zostal 5 czerwca 1253 r. odwolany $z$ administracji biskupstwa lubeckiego z powodu osiągnięcia dochodów z biskupstwa ryskiego. Ze strony papiestwa była to próba skłonienia go do udania się do Inflant, podjęta bez udziału Krzyżaków, a może i przeciw nim. Ci ostatni w niełaski Kunii popadli już w r. 1252. Por. K. Forstreuter, Der Deutsche Orden am Mittelmeer, Bonn 1967, s. 207 n.. J. P owierski, Polityka..., s. 331.

184 Vetera Monumenta I nr 111; LUB VI nr 2733.

135 LUB I nr 248, 249, 253. 
siadaniu Krzyżaków, bądź miały się wkrótce znaleźć w ich rękach ${ }^{138}$. Przy podziale tym opierano się na pochodzącym z r. 1237 rozgraniczeniu diecezji ryskiej, kurońskiej i semigalskiej, dokonanym przez legata Wilhelma $\mathrm{z}$ Modeny ${ }^{137}$. Na tej podstawie włączono do diecezji kurońskiej tereny między Windawą a Niemnem (zatoką Kurońską aż do Kłajpedy). W ten sposób zabezpieczał się biskup Henryk przed mającym powstać biskupstwem litewskim, do którego powinna normalnie należeć Żmudź.

Według Livländische Reimchronik Mendog już w momencie przyjęcia chrztu obiecał Zakon wynagrodzić ${ }^{138}$. Nie wgłębiając się zbytnio w kwestię autentyczności dokumentów Mendoga, jako że problem ten znalazł już w literaturze odpowiednie odzwierciedlenie, należy podkreślić, że większość badaczy opowiedziała się za autentycznością części tych dokumentów, inne uznając za współczesne falsyfikaty ${ }^{139}$. Nie ulega wątpliwości, że autentyczny jest dokument wystawiony przez Mendoga w lipcu 1253 r., którego actum odnosi J. Powierski do momentu koronacji w 1252 r. ${ }^{140}$ Przypuszcza się, że obietnicę tej darowizny uzyskał Zakon już w momencie pertraktacji z Mendogiem. Potwierdzenia jej dokonano w formie ustnej w czasie koronacji ${ }^{141}$. Nadanie zostało zatwierdzone przez papieża 21 sierpnia 1253 r. w oparciu o petycję i doniesienie krzyżackie, nie zaś o dokument Mendoga, który aczkolwiek wystawiony w lipcu, nie mógł już w sierpniu znaleźć się we Włoszech ${ }^{142}$. Zatwierdzenie papieskie pozwala nam zorientować się, jakie było pierwotne nadanie władcy litewskiego. A było ono o wiele skromniejsze niż to, które uzyskał Zakon w lipcu tegoż roku. Widocznie Mendog miał swym dobroczyńcom wiele do zawdzięczenia.

Darowizna Mendoga obejmowała całą południowo-zachodnią część Żmudzi i część ziemi jaćwięskiej. W rękach krzyżackich wraz z ziemią

${ }^{136}$ S. Zajączkowski, Studia..., s. 88-90.

137 LUB I nr 153; S. Z a ją c zk owski, jw., s. 87.

138 LR s. $80-81$.

139 J. Latkowski, Mendog s. 427-453; J. Totoraitis, Die Litauer..., s. 89 (uw. 1); A. Prochaska, Dwa objaśnienia do dziejów Litwy, KH 20 (1906) s. 64-73; W. Kętrzyński, O dokumentach Mendoga, [w:] Rozprawy Akademii Umiejętności. Wydzią Humanistyczny, t. 25 (L), Kraków 1907; S. Z a ją c z k o w s k i, Studia..., s. 66-110; Fr. P a pé e Poczatki Litwy, KH 41 (1927) s. 474; por. uwagi A. Seraphina do PrUB I $2 \mathrm{nr}$ 16, 39, 40, 79, 106, 136; Ph. Klymenk o, Die Urkunden Mindowes für den livländischen Orden, "Altpreussische Forschungen" 2 (1936) s. 201-219; H. Łow mi án ski, Studia..., t. 2 s. $320-327$; K. M a leczyński, W sprawie autentyczności dokumentów Mendoga $z$ lat 1253-1261, „Ateneum Wileńskie” 11 (1936) s. 1 nn.; M. Tumler, Der Deutsche Orden im Werden, Wachsen und Wirken bis 1400 mit einem Abriss der Geschichte des Ordens von 1400 bis zur neusten Zeit, Wien 1955, s. 276-278. W pracach tych można znaleźć starszą literaturę przedmiotu.

${ }_{140}$ PrUB I $2 \mathrm{nr} 39$; J. Powierski, Swiętopełk gdański..., s. 80-81; por. też $\mathrm{K}$. M a le c z y ńs ki, W sprawie autentyczności..., s. 16-20.

141 J. P owierski, Swiętopełk gdański..., s. 81.

142 PrUB I nr 274; S. Z a ją c zkowski, Studia..., s. 69-70; J. Powierski, Swiętopetk gdański..., s. $80-81$. 
Ceclis (północno-zachodnia Żmudź) miało znaleźć się $3 / 4$ ziemi żmudzkiej. Król litewski pozostawił sobie niewielką jej część od Poniewiaża do Bakajn aż po Windawę ${ }^{148}$. Mendog darował Zakonowi ziemię, której nie posiadał, za to wrogo do niego usposobioną ${ }^{144}$. Dla Zakonu fakt ten miał znaczenie drugorzędne. Wystarczała mu bowiem fikcja, która uprawniała do wydawania odpowiednich aktów prawnych w Kurii. Zresztą stworzyli oni także fikcję rzekomego zwierzchnictwa Litwy nad Zelonią, by w sporze $\mathrm{z}$ arcybiskupem $\mathrm{o}$ te ziemie, znajdujące się już $\mathrm{w}$ posiadaniu Krzyżaków, wyciągnąć dla siebie maksymalne korzyści ${ }^{145}$. Poprzez darowiznę większej części Żmudzi zyskiwali Krzyżacy tytuł prawny do tej ziemi, zabezpieczali się także przed ewentualnymi pretensjami arcybiskupa ryskiego, a także biskupa litewskiego, dla którego przewidziano uposażenie obejmujące po połowie ziem otrzymanych przez Zakon ${ }^{146}$.

Sprawa biskupstwa litewskiego w tym czasie finalizowała się w Kurii. W dniu, kiedy Zakon uzyskał potwierdzenie donacji Mendoga (21 sierpień 1253 r.), wystawił Innocenty IV bullę, z której dowiadujemy się, że król litewski zwrócił się uprzednio do Kurii z prośbą, by na biskupstwo litewskie został wyniesiony kapłan krzyżacki Chrystian, mający duży udział w dziele nawrócenia króla ${ }^{147}$. Zestawienie tego faktu z równocześnie prowadzoną przez Zakon akcją obsadzania biskupstw pruskich przez członków Zakonu ${ }^{148}$ wskazuje na wyraźny wpływ Krzyżaków, którym udało się całkowicie pominąc $\mathrm{w}$ tych zasługach episkopat inflancki.

Innocenty IV przychylił się do próśb króla i nakazał arcybiskupowi Albertowi wyświęcić Chrystiana na biskupa litewskiego ${ }^{149}$. Sama postać Chrystiana otoczona jest mrokiem. Przypuszcza się, że pochodził z diecezji münsterskiej ${ }^{150}$. Jeśli przyjąć hipotezę Willa, Chrystian był autorem kroniki mogunckiej, doprowadzonej do roku $1252^{151}$. Nie znamy ani miejsca, ani czasu konsekracji biskupiej Chrystiana. Przypuszcza się, że miała ona miejsce jesienią 1253 r., a konsekrował go arcybiskup Albert ${ }^{152}$. Ten

148 PrUB I 2 nr 39; K. M a leczyński, jw., s. 51.

144 S. Z a ją c zkow ski, Studia..., s. 74 .

$145 \mathrm{H}$. Eow miańs ki, Studia..., t. 2 s. 327.

146 LUB I nr 263.

147 PrUB I 2 nr 273; LUB I nr 254.

148 J. P owierski, Swiętopełk gdański..., s. 42-46; 49-52, 56-61.

149 PrUB I nr 273; LUB I nr 254.

150 K. Chodynicki, Próby..., s. 242.

$151 \mathrm{C}$. W ill, Über den Verfasser des Chronicum Moguntinum, „Historisches Jahrbuch" 2 (Münster 1882) s. 335 nn.; Liber de calamitate ecclesiae Moguntinae, MGH-SS 25 s. 236-248.

152 Wł. A braham (Powstanie organizacji, s. 153 p. 2) przypuszczał, że konsekrację biskupa Chrystiana poprzedziła konsekracja polskiego kandydata na biskupstwo litewskie - dominikanina Wita. Wit zostal konsekrowany po 1 listopada 1253 r., prawdopodobnie pod koniec tego miesiąca. Zatem konsekracja Chrystiana musiałaby nastąpić gdzieś na początku grudnia 1253 r. (por. niżej s. 52). Wywód ten jest niepewny, albowiem już w październiku $1253 \mathrm{r}$. w otoczeniu biskupa naumburskiego Teodoryka występuje trzech biskupów, z których „unus erat de ordine 
ostatni próbował odciągnąc Chrystiana od związków z Zakonem poprzez odebranie przysięgi obediencyjnej na swe imię, zignorowawszy w tym względzie wytyczne Kurii oraz życzenia Mendoga i Krzyżaków ${ }^{153}$. W ten sposób usiłował Albert podporządkować nowe biskupstwo litewskie swej metropolii. Czyn arcybiskupa spotkał się z natychmiastową kontrakcją w Kurii. Jej rezultatem było unieważnienie przysięgi obediencyjnej Chrystiana we wrześniu 1254 r. ${ }^{154}$ Papież nakazał wówczas biskupowi naumburskiemu przyjąć nową przysięgę Chrystiana, złożoną na imię papieża, co miało oznaczać bezpośrednią zależność biskupstwa litewskiego od Stolicy Apostolskiej.

Mimo iż egzempcja biskupstwa litewskiego leżała w interesie Krzyżaków, należy zastanowić się, czy nie mogła ona być w ostateczności korzystna dla państwa litewskiego. W wypadku chrystianizacji, przeprowadzonej po myśli króla, mogła być ona wstępem do uzyskania własnej metropolii. Powołanie metropolii zawsze leżało w interesie nowo nawróconych społeczeństw.

Biskup litewski Chrystian pojawił się na Litwie w pierwszych miesiącach r. $1254^{155}$, a już 12 marca wystawił Mendog akt uposażenia bis-

Cisterciensium, alter de ordine minorum, tertius de ordine domus The utonic e" (Annales Erphordenses; cytuję za: C. W ill, jw., s. 372; 1253 Nonas Octobris). Przyjmuje się, że tym biskupem krzyżackim był Chrystian (K. Chodynicki, Próby..., s. 232 p. 4; K. Male czyński, jw., s. 53-54). Zatem już w październiku $1253 \mathrm{r}$. był on wyświęcony, a więc jego konsekracja poprzedziła konsekrację Wita. W owych czasach były to jednak akty prawie równoczesne. Jeśli rzeczywiście Chrystian występował w otoczeniu biskupa Teodoryka, należałoby się zastanowić, czy to czasem nie biskup naumburski oraz wymienieni wyżej biskupi, cysters i franciszkanin, nie byli wraz z Albertem współkonsekratorami biskupa litewskiego. Papież bowiem polecił Albertowi, by ten konsekrowal biskupa dla Litwy, ,associatis duobus vel tribus convicinis episcopis" (LUB VJ nr 2733). Przyjęcie tej hipotezy pozwala lepiej zrozumieć, dlaczego papież zwrócił się potem właśnie do biskupa naumburskiego, by unieważnił przysięgę obediencyjną Chrystiana, złożoną arcybiskupowi Albertowi (LUB I nr 272).

153 Dowiadujemy się o tym z bulli papieskiej z 3 września 1254 r. (LUB I nr 272). Abp Albert tłumaczył się, jakoby w chwili konsekracji nie otrzymał jeszcze bulli papieskiej w sprawie egzempcji biskupstwa litewskiego z 21 sierpnia $1253 \mathrm{r}$. (PrUB I $\mathrm{nr}$ 273; LUB I $\mathrm{nr} 254$ ).

154 LUB I nr 272, 273; Reg. nr 308. 20 września 1254 r. Innocenty IV skierował dwie bulle: do biskupa Chrystiana i biskupa Dorpatu, w których ponowił orzeczenie o unieważnieniu przysięgi Chrystiana, o wyjęciu diecezji litewskiej spod jurysdykcji arcybiskupa i jej egzempcji. Papież przyznał Albertowi jedynie opiekę nad biskupstwem litewskim, natomiast biskupa Dorpatu upoważnił do użycia, w razie potrzeby, kar kościelnych. Bullę podobnej treści otrzymał zapewne i Albert (J. L a t k ow s ki, jw., s. 362; LUB I nr 275; Vetera Monumenta I nr 121).

155 M. Kosman (Zmierzch Perkuna..., s. 123) uważa, że bp Chrystian jeszcze 12 marca 1254 r. nie zajmował urzędu biskupiego, a był zaledwie królewskim kandydatem na biskupa. Biskupem tytułował się dopiero w Rydze 6 kwietnia $1254 \mathrm{r}$., zatem objął rząd po 12 marca, ale przed 6 kwietnia tr. Wiemy, że bp Chrystian został konsekrowany w roku ubiegłym. Mendog mówił o biskupie w sposób następujący: ,[...] quod nos de maturo consilio nostrorum recepimus (!) venerabilem patrem dominum Christianum, quem consecrari postulavimus in episcopum regni nostri" (LUB I nr 263; Gedimino laiškai, ed. V. P a š u ta et J. Š ta l, Vilnius 1966, s. 20, nr 1). Być może, król nic jeszcze nie wiedział o konsekracji Chrystiana, lub oczekiwał jego przyjazdu. 
kupstwa ${ }^{156}$. Wokół tego nadania narosło wiele hipotez. Zlokalizowane było ono bowiem nie na Litwie właściwej, ale na Żmudzi ${ }^{157}$. W. Kętrzyński na tej podstawie wątpił nawet $\mathrm{w}$ autentyczność samego nadania, uważając, że przecież Mendog miał być główną podporą biskupstwa ${ }^{158}$. S. Zajączkowski uważał nadanie za autentyczne, podkreślając, że ,istnienie biskupstwa litewskiego zależne było przede wszystkim od poparcia Zakonu". Wskazywać miała na to lokalizacja dóbr ofiarowanych biskupowi ${ }^{159}$. $\mathrm{Z}$ poglądem tym zgadzał się zasadniczo $\mathrm{H}$. Łowmiański, widząc $\mathrm{w}$ fakcie fikcyjnego uposażenia biskupstwa na Żmudzi, zdobywanej wówczas przez Zakon, słabość władztwa terytorialnego Mendoga ${ }^{160}$.

Podkreślano często, że Mendog musiał sobie zdawać sprawę z tego, iż Zakon w stosunku do niego postępuje dwuznacznie. Dlatego nie był nadmiernie zapalony do realizacji krzyżackiej koncepcji chrztu Litwy ${ }^{161}$. Wspólne interesy już się bowiem skończyły. Mendog utrzymał się na Litwie, a Krzyżacy i biskup otrzymali nadania na Żmudzi, nad którą faktycznie wówczas nie panował. J. Latkowski postawił hipotezę, że uposażenie biskupstwa połówkami ziem, których drugie połowy otrzymali Krzyżacy, miało w zamyśle króla hamować tym ostatnim drogę do uzyskania całych ziem ${ }^{162}$. Natomiast $\mathrm{K}$. Maleczyński zauważył, że w razie pomyślnego przeprowadzenia chrystianizacji Żmudzi wcielenie biskupiego terytorium do państwa zakonnego nie było sprawą bardzo trudną ${ }^{168}$. Że takie projekty istniały, dowodzi fakt, iż już w miesiąc po uposażeniu biskupstwa 6 kwietnia $1254 \mathrm{r}$. Chrystian ustąpił Zakonowi dziesięcinę $\mathrm{z}$ przyznanych braciom ziem żmudzkich ${ }^{164}$. Zrzeczenie się praw biskupich $\mathrm{z}$ tego terenu było wstępem do zupełnego uniezależnienia ich od diecezji litewskiej, do której zapewne miały należeć. Akt uposażenia biskupstwa litewskiego nasuwa analogię do zwyczajów inflanckich, gdzie podbite terytorium dzielono między biskupstwa i Zakon ${ }^{165}$. Ta polityka Chrystiana i Zakonu nie mogła ujść uwagi Mendoga. Stąd brak królewskiego poparcia akcji misyjnej na Litwie.

Chrzest Mendoga był wywołany zagrożeniem zewnętrznym i nosił

${ }^{156}$ LUB I nr 263: „[...] assignantes etiam eidem pro dote Rassegene medietatem, Betegallen medietatem, Lokowe medietatem". W prawie identyfikacji por.: S. Z ajączkowski, KH 46 (1932) s. 466-468; K. Maleczyński, jw., s. 55 (p. 326).

${ }_{157} \mathrm{H}$. Paszkiewicz, jw., s. 93; S. Zajączkowski, Studia..,, s. 74.

158 W. Kętrzyński, O dokumentach Mendoga..., s. 196 (uw. 2).

159 S. Zajączkowski, jw., s. 70 (p. 7).

160 H. Łow miański, Studia..., t. 2, s. 342.

161 H. Paszkiewicz, jw., s. 92-94, 102-104.

162 J. Latk ow ski, jw., s. 361 .

$163 \mathrm{~K}$. Ma leczyń ski, jw., s. 326.

164 LUB I $\mathrm{nr}$ 266. Zatem ziemie darowane przez Mendoga Zakonowi miały należeć jurysdykcyjnie do diecezji litewskiej. S. 162 .

${ }_{165} \mathrm{~W}$. Kamieniecki, Wpływy zakonne na ustrój litewski, PH 25 (1925) 
wszelkie znamiona aktu politycznego, dla którego cechą charakterystyczną jest koniunkturalność. Zdawał sobie z tego sprawę kronikarz ruski, pisząc, że „,kreszczenie że jego [Mendoga] lstiwo byst” ${ }^{166}$. Mendog jako najwyższy kapłan kultu pogańskiego miał nadal oddawać cześć dawnym bogom potajemnie. M. Kosman dowiódł, że synkretyzm religijny jest zjawiskiem charakterystycznym i często spotykanym wśród neofitów. Bóg chrześcijański powiększył tylko panteon bóstw litewskich. Wyrażenia bulli papieskich, że Mendog przyjął chrzest „cum numerosa multitudine paganorum" ${ }^{167}$, były sformułowane bardziej na wyrost. Dla Kurii było rzeczą naturalną, że za chrztem władcy pójdzie chrzest poddanych ${ }^{168}$. Że jednak pozostawała jeszcze spora liczba pogan, świadczą o tym same bulle papieskie ${ }^{169}$. Pogańskie oblicze Litwy tego czasu podkreślają i inne świadectwa źródłowe ${ }^{170}$. Wszystko wskazuje na to, że Mendog nie starał się zniszczyć miejsc kultu pogańskiego i narzucić nowej wiary poddanym. Zadowolił się zapewne budową katedry i być może likwidacją kultu pogańskiego w większych ośrodkach.

Z roku 1255 pochodzi świadectwo biskupa Chrystiana; skarżył się on papieżowi, że Mendog nie broni go przed poganami, którzy ,suam dioecesim" zewsząd atakują ${ }^{171}$. Bulla dowodzi, że przeciw biskupowi występowali także poddani Mendoga. Nie dziwi zatem fakt, że Chrystian uważał Krzyżaków za swą podporę, podkreślając, że bez ich pomocy Kościół nie tylko nie mógłby wzrastać, lecz także się utrzymać ${ }^{172}$.

Nie doszło do zorganizowania kapituły biskupiej ${ }^{173}$, nie słyszymy nic o sieci parafialnej, o zakładaniu kościołów. Wprawdzie na Litwie powsta1 konwent krzyżacki, ale jego zadaniem nie była chrystianizacja kraju.

Pewne wysiłki w kierunku chrystianizacji jednak istniały. Andrzej von Stirlant zostawił na Litwie duchownych, którzy mieli pracować nad likwidacją pogaństwa ${ }^{174}$. Biskup Chrystian musiał też mieć jakąś świtę. Autor nie znanego dotąd źródła, przechowywanego w Irlandii (Descrip-

166 PSRL II 817.

167 MPV III $\mathrm{nr} 67$.

168 M. Kosm a n, Zmierzch Perkuna..., s. 110-120.

169 MPV III $n r$ 67: ,[...] regnum Luthawie ac terras omnes, quas per divine virtutis auxilium iam eripuisti de infidelium manibus vel eripere poteris in futurum"; Vetera Monumenta I $\mathrm{nr}$ 106: ,cum itaque dicti regis ad hoc ferventer aspiret affectio, ut per suffragium sancte Romane ecclesie ad viventis Dei notitiam multitudo circumstantium paganorum adhuc manens in errore devio conventatur..."; PrUB I nr 312: papież żądał, by król biskupa litewskiego „,contra paganorum s u a m dioecesim undique impugnantium et aliorum invasorum incursus, item contra tue iurisdictioni subiectos protegas et defendas".

170 PSRL II 817.

171 PrUB U nr 312.

172 LUB I nr 266.

173 PrUB I 2 nr 87: ,episcopus Lettowie [...] loci dioecesanus, qui nullum capitulum obtinet".

174 LR s. 82.

4 - Analecta Cracoviensia 
tiones terrarum), stanowiącego wstęp do zaginionego opisu Tatarów, stwierdza, że Litwini, Jaćwież i Nalszczanie z łatwością przyjmują chrzest, gdyż od kolebki wykarmieni są przez mamki chrześcijańskie; stąd można było wśród nich „,najbezpieczniej przebywać” ${ }^{175}$.

Być może Mendog starał się przeprowadzić chrystianizację z pominięciem swych dobroczyńców i miał własną koncepcję urządzenia Kościoła na Litwie. Wiemy niestety tylko tyle, że nie wspierał specjalnie biskupa Chrystiana, mimo iż wcześniej chciał widzieć jego osobę na biskupstwie litewskim. Widocznie to pragnienie królewskie stymulował ktoś inny. Jednocześnie król litewski zmierzał do ugruntowania pozycji swego rodu i to w oparciu o Kościół. Bo to właśnie on zwrócił się do Kurii z prośbą o zgodę na koronację swego syna, pragnąc $w$ ten sposób zapewnić sobie ciągłość swego dzieła, jakim było zachowanie całości „królestwa Litwinów złożonego z Litwy i ziem ruskich". Papież potwierdził Mendogowi wszystkie nabytki dokonane na Rusi ${ }^{176}$.

Interesujące jest to, że bulla papieska $\mathrm{w}$ tej sprawie została wydana 6 marca 1255 r., natomiast upomnienie w sprawie biskupa Chrystiana 7 marca tegoż roku ${ }^{177}$. Czy nie należy widzieć w tym fakcie natychmiastowej reakcji dyplomacji krzyżackiej wobec samodzielnych zabiegów Mendoga w Kurii, prowadzonych z ich pominięciem? Autor Descriptiones terrarum, pomijający całkowicie rolę Krzyżaków w dziele chrystianizacji państw nadbałtyckich, o Mendogu napisał, że król „otrzymawszy swe królestwo od Stolicy Rzymskiej to [królestwo] pozostawił swoim następcom do uczynienia, jeżeli do tego czynu przyłożą pilne starania ${ }^{178}$. Swiadectwo to pośrednio popiera domysł, że Mendog miał własne plany odnośnie do przyszłości swego królestwa i swym następcom przygotowywał odpowiedni grunt.

Trudno wyobrazić sobie, by biskup Chrystian pisał podobną skargę do Kurii bez wiedzy Krzyżaków. Dowodzi to poniekąd, że pod koniec $1254 \mathrm{r}$. stosunki między Mendogiem a Zakonem uległy ochłodzeniu i rozluźnieniu. Jesienią tego roku Zakon pruski zawarł w Raciążu porozumienie z Danielem halickim i Siemowitem mazowieckim, dotyczące ekspektatywnego podziału Jaćwieży ${ }^{179}$. Wiemy, że Jaćwięgowie po roku 1252 zostali przez Mendoga przekupieni i odstąpili wraz ze Żmudzinami z obozu wrogów króla litewskiego. Naraziło to ich na represje Daniela pretendującego do

175 K. Górski, Descriptiones Terrarum..., s. 9; G. Labuda, [Artykul recenzyjny] Sź 28 (1983) s. 257-259; J. O c h mańs ki, Nieznany autor..., s. 107114. Źródło powstało przed apostazją Mendoga i odzwierciedla sytuację polityczną $\mathrm{z}$ lat $1255-1261$.

176 Vetera Monumenta I nr 123; por. H. Paszkiewicz, jw., s. $73 \mathrm{n}$.

177 PrUB I nr 312.

178 K. Górski, jw., s. 9.

179 PrUB I nr 298. 
podporządkowania sobie całego ich terytorium ${ }^{180}$. Porozumienie krzyżacko-mazowiecko-ruskie mogło być zatem obliczone również na zaszachowanie władcy litewskiego, który zapewne nie był skłonny do przekazania Krzyżakom ziem jaćwięsko-żmudzkich, obiecanych tymże jeszcze przed rozbiciem ich obozu. Warto zwrócić uwagę, że nadanie Mendoga dla Krzyżaków z r. 1253 było znacznie hojniejsze niż późniejsze nadanie dla biskupa Chrystiana z 12 marca 1254 r. Biskup nie otrzymał bowiem ani połowy Eiragoły, ani połowy ziemi dojnowskiej (jaćwięskiej), których drugie połowy otrzymał Zakon ${ }^{181}$.

W momencie nadania dla Zakonu Mendog ziem tych po prostu nie posiadał, ale większość $\mathrm{z}$ nich uznawała zapewne jego władzę w roku 1254. Można zatem przypuszczać, że Zakon otrzymał faktycznie tylko te ziemie, które nadał mu Mendog wespół $\mathrm{z}$ biskupem litewskim, a więc włości: rosieńską, ławkowską i betygołską. O realizacji zobowiązań co do Jaćwieży i Nadrowii (związanej z tą pierwszą) nie było już zapewne mowy.

Pod koniec tego roku Mendog zawarł porozumienie z Danielem w Chełmie ${ }^{182}$. Nie wiemy dokładnie, czy porozumienie to poprzedziło układ raciąski, czy nie. Wszystko wskazuje jednak na to, że układ litewsko-ruski w Chełmie był konsekwencją ugody raciąskiej. Aby zerwać konszachty rusko-krzyżackie, musiał Mendog ofiarować Danielowi więcej niż dawali Krzyżacy. I Mendog te wymogi spełnił, osadzając na Rusi Czarnej w charakterze swego lennika syna Daniela - Romana ${ }^{183}$. Układ przewidywał zapewne także wzajemną pomoc zbrojną. Wiemy bowiem, że w roku 1255 Daniel wezwał na wyprawę zwiahelską posiłki litewskie ${ }^{184}$. Przypuszcza się, iż Mendog zgodził się także na podporządkowanie Rusi części terytorium Jaćwieży ${ }^{185}$ — zapewne i tego, do którego pretensje rościł sobie Zakon. Ten ostatni w r. 1255 z pomocą Przemysła Ottokara II podbił Sambię i prawie natychmiast przystąpił do podboju sfederowanej z Jaćwieżą Nadrowii ${ }^{186}$. W roku tym powstały także polsko-czeskie plany w stosunku do ziem litewsko-jaćwięskich ${ }^{187}$, być może inspirowane przez Krzyżaków, którzy traktowali je jako środek nacisku na króla litewskiego. W ciągu r. 1255 miała być głoszona krucjata przeciw Litwinom

180 Por. niżej s. 54.

181 Krzyżacy bowiem otrzymali „Rasseyene medietatem, Lukowe medietatem, Betegalle medietatem, Eregalle medietatem, Deynowe medietatem, Kulene totum, Karsowe totum, Crase totum, Nederowe totum, Weyze totum, aliud Weyse totum, Wange totum" (PrUB I $2 \mathrm{nr}$ 39). Natomiast Chrystian otrzymał tylko połowę włości rosieńskiej, betygolskiej i lawkowskiej (LUB I nr 263).

182 PSRL II $830-831$.

183 Tamże.

184 Tamże, s. 838.

185 B. Włodarski, Polska $i$ Ruś..., s. 176.

${ }_{186}$ Dusburg, s. 92 nn.; por. J. P o wierski, Rola Jaćwieży..., s. 100.

187 J. P o wierski, Sprawa Prus $i$ Jaćwieży..., s. 257. 
i Jaćwięgom na terenie Polski, Czech i Moraw ${ }^{188}$. Nie słyszymy o żadnej kontrakcji Krzyżaków przeciw niej, chociaż poóźniej reagowali natychmiastowo.

Mendog bez pomocy Zakonu niewiele mógł w Kurii zdziałać. Nie posiadał bowiem wyspecjalizowanej służby kancelaryjno-dyplomatycznej ${ }^{189}$. Trudno byłoby mu przekonać świat chrześcijański, że jego ziemie już zostały schrystianizowane, gdyż faktycznie nie poczynił w tym zakresie żadnych energiczniejszych kroków. Nie był też pewny swych poddanych, wśród których konserwatyzm plemienny był jeszcze bardzo silny. A nowa religia wymagała utrzymania duchowieństwa właśnie ich kosztem poprzez nadania dóbr ziemskich z ludnością chłopską i nałożenia dziesięcin ${ }^{190}$. Do tego zaś wczesna monarchia Mendoga nie była zdolna i dlatego król musiał pójść na kompromis z Krzyżakami. Jesienią 1255 r. stosunki Mendoga z Krzyżakami były znów poprawne, gdyż król uczynił na prośbę Zakonu inflanckiego fikcyjne nadanie Zelonii ${ }^{191}$, a także zwrócił się do Kurii o potwierdzenie swych nadań na rzecz Krzyżaków ${ }^{192}$. Natomiast Zakon u schyłku tego roku planował wyprawę na Jaćwież, która jednak nie doszła do skutku z powodu powstania Sambów ${ }^{193}$. W szeregi powstania wstąpili wkrótce Żmudzini, rozczarowani polityką Mendoga.

$\mathrm{Na}$ czele powstańców żmudzkich stanął Aleman, nieprzyjaźnie nastawiony do króla litewskiego ${ }^{194}$. Inflancka kronika rymowana podaje, że był on przejęty bólem i gniewem $\mathrm{z}$ powodu przyjęcia chrześcijaństwa przez Mendoga i część Litwinów. Na Żmudzi, ciągle zagrożonej podbojem, chrześcijaństwo traktowano jako wrogą, obcą religię, a przywiązanie do tradycji pogańskich wzrastało tam wprost proporcjonalnie do krzyżackich wysiłków, zmierzających do ich unicestwienia. „Na Żmudzi nigdy bez miecza nie głoszono słowa bożego", stwierdza autor przechowywanej w Irlandii kroniki, potwierdzając raz jeszcze, że chrześcijaństwo w tej „,ziemi pogan" nigdy nie krzewiło się w sposób pokojowy ${ }^{195}$.

W r. 1256 Aleman wkroczył do Kuronii i ją spustoszył. Sprowadziło to wielką wyprawę krzyżacką na Żmudź pod wodzą landmistrza Annona von Sangerhausena. Z pomocą trzech zbiegłych do Inflant kunigasów żmudzkich pustoszył on przez dziewięć dni ziemię żmudzką ${ }^{196}$. W r. 1257 nowym landmistrzem Inflant został Burchard von Hornhausen. O mało co

188 PrUB I nr 322.

$189 \mathrm{~K}$. M a le czyński, jw., s. 54; M. Kosman, Kancelaria wielkiego księcia Witolda, SŹ 14 (1969) s. 95-97.

190 J. P owierski, Zanik pogaństwa..., s. 555-556.

191 LUB I nr 286; por. H. E ow miański, Studia..., t. 2 s. 325.

192 LUB I nr 287. Co do autentyczności tych dokumentów por. K. M a l e c z ýnski, jw., s. 38-43.

198 B. Wło d a r ski, Rywalizacja..., s. 48-49.

194 LR s. $94-95$.

$195 \mathrm{~K}$. Górski, Descriptiones Terrarum..., s. 9.

196 LR s. $96-99$. 
nie dostał się on do niewoli żmudzkiej podczas próby wizytacji Kłajpedy ${ }^{197}$. Z przekazu kroniki inflanckiej wiemy, że nowy landmistrz i Mendog wymienili między sobą podarunki, a przyjaźń ta nie podobała się Żmudzinom ${ }^{198}$. Możliwe, że powstanie żmudzkie wpłynęło na zacieśnienie więzów króla litewskiego z Krzyżakami. Nic już bowiem o skargach biskupa litewskiego nie słyszymy. Jesienią 1257 r. Żmudzini wyczerpani walką poprosili Zakon o dwuletni rozejm, na co ten skwapliwie wyraził zgodę $^{199}$. Żmudzini zdawali już sobie sprawę, że nie można marzyć o likwidacji potęgi Zakonu bez współdziałania z władcą litewskim.

W tym czasie Litwini podejmują szereg wypraw na Ruś mongolską, do której ziem otrzymał Mendog prawo od papieża już w r. $1255^{200}$. Sprowadziło to na Litwę zimą 1258/9 r. okrutny najazd tatarski Burundaja, z którym współdziałali Rusini halicko-wołyńscy. Zostały spustoszone ziemie litewska i nalszczańska ${ }^{201}$. Autorytet Mendoga uległ zapewne zachwianiu pomimo tego, iż udało mu się najcięższe chwile przetrwać. Wspomagali go Wojsiełk i Towtywił, którym udało się nawet wziąć do niewoli Romana Daniłowicza ${ }^{202}$. Natomiast po najeździe opuścił Litwę biskup Chrystian, by się już tu więcej nie pokazać ${ }^{203}$. Żmudź, wroga państwu litewskiemu, nie została dotknięta najazdem tatarskim.

W r. 1259 po upływie rozejmu wznowione zostały walki krzyżacko-żmudzkie. Wojska krzyżackie z Kłajpedy i Goldyngi z posiłkami Kurów pod dowództwem Bernarda von Haren zostały rozbite na polu Schoeten w pobliżu Szkud ${ }^{204}$. Klęska Zakonu w Kuronii zapewne zaniepokoiła Mendoga, który osłabiony po najeździe tatarskim mógł czuć się zagrożony najazdem żmudzkim i być może buntem własnych poddanych, podekscytowanych sukcesem pobratymców. Dlatego król litewski zacieśnił swoje więzi z Zakonem poprzez nadanie mu 7 sierpnia $1259 \mathrm{r}$. całej Jaćwieży z wyjątkiem trzech włości i czterech wsi, zapewne faktycznie przez niego dzierżonych, oraz całej Skalowii i Żmudzi z wyjątkiem dóbr, które zostały przeznaczone na uposażenie biskupstwa litewskiego ${ }^{205}$.

197 LR s. $103-104$.

198 LR S. $102-103$.

199 LR s. 104-106; S. Z a ją c z k ow ski, Studia..., s. 94.

200 Regesta Lithuaniae $\mathrm{nr} 351,356,357$; Vetera Monumenta I nr 123.

201 PSRL II 846-848; por. Regesta Lithuaniae mr 359.

202 PSRL II $847-848$.

203 Wl. Abraham, Powstanie organizacji..., s. 155 . W r. 1259 bierze udział w konsekracji kościoła klasztornego Floridi Orti w diecezji münsterskiej (MGH-SS 23 s. 547).

204 LR s. $106-112$.

205 PrUB I 2 nr 79; por. J. P o w i e r ski, Ksiązęta polscy..., s. 373. Interesujące są w tym czasie poczynania Krzyżaków w kwestii tatarskiej. 25 stycznia 1260 r. Aleksander IV przyjął w opiekę Stolicy Apostolskiej wszystkie ziemie, które Zakon na Rusi lub na Tatarach, jako zwierzchnikach Rusi, zdobędzie, za zgodą tych, do których dawniej należały (Litwa?), postanarwiając by biskupi i kler grecki, gdy powrócą do jedności kościelnej zatrzymali swe stanowiska (LUB I nr 345). Bulla ta może oznaczać, że Krzyżacy obiecali wcześniej Mendogowi siwą pomoc przeciw 
Krzyżacy zabrali się natychmiast do energicznej akcji i w darowanej im włości korszowskiej wznieśli zamek na górze św. Jerzego (Georgenburg) ${ }^{206}$. Pod koniec roku wybuchł bunt Semigalów, poparty przez Żmudzinów ${ }^{207}$. Walki ciągnęły się aż do roku 1260 i zakończyły się wspaniałym zwycięstwem Żmudzinów nad Zakonem krzyżackim nad jeziorem Durbe ${ }^{208}$. W bitwie zginął landmistrz Burchard, marszałek pruski Henryk Botel, 150 krzyżaków i wielu rycerzy. Charakterystyczne, że inflancka kronika rymowana jeszcze przed bitwą durbeńską nazywa Żmudzinów Litwinami ${ }^{209}$. Świadczy to, że do walki Żmudzinów przyłączyły się pewne grupy poddanych Mendoga, niezadowolonych z jego polityki.

Klęska krzyżaków spowodowała wybuch II powstania pruskiego ${ }^{210}$. Zawarty został sojusz żmudzko-kuroński. Wyparto Krzyżaków z włości korszowskiej, całej południowej Kuronii, Semigali i Ozylii ${ }^{211}$. Kontakt między Inflantami i Prusami został przerwany. W lutym 1261 r. Zakon inflancki poniósł kolejną klęskę pod Lielvārde. Na wyspie Ozylii wybuchło powstanie antykrzyżackie ${ }^{212}$. Panowanie Niemców w Inflantach stanęło pod znakiem zapytania.

Pod wpływem pogromu krzyżaków na Litwie zdobyło sobie przewagę stronnictwo pogańskie. Na jego czele stanął Trojnat, przebywający $\mathrm{w}$ tym czasie $\mathrm{w}$ otoczeniu króla ${ }^{213}$. Do Mendoga udało się poselstwo żmudzkie obiecujące oddanie królowi tego, „co mu się słusznie należy”, żądające jednak zerwania z chrześcijaństwem, które Żmudzini z pewnością utożsamiali z sojuszem z Zakonem ${ }^{214}$. Mendog wahał się. Władca litewski widział zapewne potrzebę chrystianizacji kraju, ale nie prowadzonej w takis posób, jaki narzucili Krzyżacy. W ówczesnych państwach feudalnych

Tatarom, ale oczywiście nie za darmo i zadbali, by w przyszłości nic na tym nie stracić. W tym samym dniu Aleksander IV potwierdził nadania Mendoga dla Zakonu oraz nadania bpa Chrystiana (PrUB I $2 \mathrm{nr} 87$ ).

208 Dusburg, s. 96.

207 IR S. $125-126$.

208 Zestawienie źródeł w: Regesta Lithuaniae nr 375.

209 LR s. 125 ; por. H. Paszkiewicz, jw., s. 76; W. T. Paszuto, Obrazowanie..., s. 284.

${ }^{210}$ Por. J. Pow ierski, Wybuch II powstania pruskiego..., s. 303-326.

211 LR s. $132-138$.

${ }^{212}$ LR s. 138 -140; S. Z Z ją c z k owski, jw., s. 98.

$213 \mathrm{~S}$. Z Z jączkowski, (jw., s. 63, 66) uważał Trojnata za syna Wykinta, usuniętego ze Żmudzi przez Towtywiła. W r. 1261 znajdował się on na dworze Mendoga. Musiał też sprzyjać stronnictwu pogańsksiemu, skoro delegacja żmudzka prosiła go 0 pośrednictwo. On też opracowal scenariusz pertraktacji z królem (S. $\mathrm{Zajączkowski,} \mathrm{jw.,} \mathrm{s.} \mathrm{101-102;} \mathrm{J.} \mathrm{Latkowski,} \mathrm{jw.,} \mathrm{s.} \mathrm{404).} \mathrm{Z} \mathrm{późniejszych}$ relacji dowiadujemy się, że przyczyną apostazji Mendoga miało być niezwrócenie przez krzyżaków siostrzeńcowi Mendoga zagrabionych mu rzeczy. Wtedy to „dictus avunculus regis [Trojnat?] intravit terram christianorum cum magno exercitu et fecit ibidem magna dampna, ex quibus postea potentiores Lythonie opposuerunt se regi predicto ita, quod ipse postmodum apostavit a fide" (A. Se raphim, Das Zeugenverhör des Franciscus de Moliano, Königsberg 1912, s. 78). O Trojnacie por.: E. Gu davič u s, Ar Treniota zemaičiu kunigaikštis?, „Lietuvas TSR Mokslu Akad. Darabei. Ser. A. Visnomenes Moksali" 4 (1982) s. 63-70. 
Kościół pełnił ważne funkcje, uzupełniające władzę państwową. Kościół , litewski” służył natomiast obcym interesom. Z drugiej strony Mendog miał możliwość wykorzystania spadku separatyzmów plemiennych w celu konsolidacji plemion litewskich i żmudzkich. Ratunkiem dla Kościoła na Litwie byłaby chrystianizacja z pominięciem Zakonu, ale w ówczesnej sytuacji było to niemożliwe. Dlatego Mendog zdecydował się na porzucenie przyjaźni z Zakonem, co w praktyce oznaczało fiasko misji chrześcijańskiej na Litwie. Stąd współczesne wypadkom źródła krzyżackie łączą zerwanie dobrych stosunków $\mathrm{z}$ apostazją od wiary chrześcijańskiej.

W wyniku porozumienia ze Żmudzinami Mendog objął zwierzchnictwo nad nimi. Nobilowie żmudzcy zadbali jednak o to, by nie było ono dla nich uciążliwe. Księciem i wodzem żmudzkim został Trojnat, zatem władza Mendoga na Żmudzi nie była sprawowana bezpośrednio ${ }^{215}$. Życie polityczne Litwy zostało zdominowane przez Żmudzinów, fanatycznych pogan i wrogów chrześcijaństwa. Chrześcijanie w państwie litewskim zostali uwięzieni, doradców krzyżackich oddalono ${ }^{216}$. Wprawdzie Mendog usiłował stanąć na czele całego ruchu ogólnobałtyjskiego, ale zapewne podeszły wiek, a może przede wszystkim brak przekonania do swej nowej polityki nie pozwoliły mu celu tego osiągnąc ${ }^{217}$. Jako osoba najbardziej wpływowa wysuwa się na czoło Trojnat. Zwycięstwa odniesione nad Krzyżakami podnoszą jego autorytet ${ }^{218}$. Po tragicznej śmienci Mendoga w roku 1263 stanął on na czele państwa litewskiego ${ }^{219}$.

Epizod chrystianizacji Litwy zakończył się niepowodzeniem. Wprawdzie około r. 1263 pojawi się jakiś biskup litewski Jan, należący do Zakonu krzyżackiego ${ }^{220}$, lecz był to tylko biskup tytularny, być może wysunięty przez Krzyżaków w celu zaznaczenia ich pretensji co do biskupstwa litewskiego wobec współczesnych zabiegów polskich ${ }^{221}$. O biskupie tym nic nie wiemy. W r. 1275 był już sufraganem w Konstancji i Frankenbergu. Zmarł w r. $1288^{222}$. Na Litwie z pewnością nigdy nie był.

Mendoga różnie $\mathrm{w}$ historiografii oceniano. Uważano go bądź za apostatę, bądź za męczennika. Gruntowne badania nad dziejami społeczeństwa i państwa litewskiego dowiodły, że sprawa ta jest bardzo złożona. Władca litewski w swej polityce był zdeterminowany rozmaitymi okolicz-

214 LR s. $145-148$.

215 PSRL II 859-860; J. P ow ierski, Stanowisko polityczne..., s. 9-12; H. Paszkiewicz, jw., s. 103. Władzy Mendoga poddali się także Jaćwięgowie.

216 LR s. 148; J. Latk ow ski, jw., s. 397. Uwięzionych chrześcijan uwolni potem Wojsiełk (LR s. 164).

217 S. Z a ją c z k o w ski, jw., s. 104.

218 Tamże, s. 105-107; H. P a szki e wicz, jw., s. 103-104.

219 Zestawienie źródel w: Regesta Lithuaniae, nr $422,428$.

220 SRP II s. 812; K. Koranyi, Do dziejów Jana, biskupa Litwy, KH LII (1938) s. $428-429$.

221 K. Chodynicki, Próby s. 248.

222 Tamże; Wł. A b r a h a m, Powstanie organizacji..., s. 155-156. 
nościami. Władza jego nie miała jeszcze charakteru stricte monarszego; silne były separatyzmy plemienne. W polityce wewnętrznej musiał liczyć się ze stanowiskiem licznej rzeszy kunigasów, których stosunek do nowej religii nie był zapewne entuzjastyczny. Nieszczęśliwy bieg wypadków politycznych opóźnił chrystianizację Litwy, co więcej - niepowodzenie tej pierwszej próby wpłynęło na późniejszy negatywny stosunek władców litewskich do chrześcijaństwa ${ }^{223}$. Spowodowało to, iż społeczeństwo litewskie zostało wystawione na twardą próbę, której wynik trudno było przewidzieć. Ocalenie mogła przynieść tylko odpowiednio dokonana chrystianizacja kraju. Litwa do decyzji tej dojrzała w drugiej połowie XIV w. i jako jedyny lud bałtyjski uniknęła losu swych pobratymców.

\section{KOSCIOE WSCHODNI NA LITWIE}

Do tej pory była mowa o wpływach chrześcijaństwa na Litwę w jego postaci zachodniej. Jednakże na Litwę oddziaływał w dużej mierze także Kościół wschodni. Sąsiadujące z Litwą ziemie ruskie były już schrystianizowane od kilku wieków i posiadały dobrze zorganizowaną sieć cerkiewną. Zwrócono jednak uwagę, że książęta ruscy nie dbali o propagowanie chrześcijaństwa $\mathrm{w}$ podporządkowanych im trybutarnie ziemiach pogańskich ${ }^{224}$. Zmiana w tym zakresie nastąpiła dopiero pod wpływem rozwijających się dynamicznie misji niemieckich, za którymi szły zamierzenia polityczne, usiłujące stworzyć państwo zakonne. W ten sposób pod bokiem Rusi wyrosły agresywne organizmy polityczne, roszczące sobie pretensje nie tylko do ziem pogan, ale także do ziem ruskich jako schizmatyckich. Niebezpieczeństwo stąd płynące dostrzegł najpierw Psków, który około r. 1207 rozwinął akcję chrystianizacyjną w podporządkowanej sobie Tolowie (Letgalia), by nie dopuścić tam misji zachodniej ${ }^{225}$. Mimo, że chrześcijaństwo wschodnie szerzyło się na Litwie w XIII w., Kościół wschodni nie zdołał doprowadzić do stworzenia organizacji cerkiewnej w tym okresie cza$\mathrm{su}^{226}$.

Jak wiemy, około połowy XIII w. uzależnione zostały od Litwy ziemie białoruskie, a następnie Ruś Czarna ${ }^{227}$. W następnym stuleciu posiadłości ruskie Litwy ogromnie wzrosły. Nie osłabiło to jednak zupełnie

223 J. P ow ierski, Zanik pogaństwa..., s. 556.

224 CL XVI 2: „Est enim consuetudo regum Ruthenorum, ut quamcunque gentem expugnaverint, non fidei christiane subicere, sed ad solvendum sibi tributum et pecuniam subiugare; CL I 3; por. H. Éow mi ański, Studia..., t. 2 s. $265-266 ; \mathrm{K}$. Chodymicki, jw., s. $249-250$.

${ }^{225}$ CL XI 7 XVIII 3.

${ }^{226} \mathrm{~K}$. Chodynicki, jw., s. 250.

227 J. Latkowski, jw., s. 304; H. Eow miański, Studia..., t. 2 s. 277-278; H. Paszkiewicz, jw., s. 69-74; H. Łow miański, Uwagi o genezie..., s. 144. 
pogaństwa na Litwie, mimo że proces recypowania ruskiej kultury posunął się tu bardzo daleko. Litewscy kunigasi, osiadający w księstwach ruskich, przyjmowali chrzest $\mathrm{w}$ obrządku wschodnim i zwyczaje ruskie ${ }^{228}$. Nie przeszkadzało im to w utrzymywaniu ożywionych związków z pogańskimi książętami Litwy, często z nimi blisko spokrewnionymi. Nie można oprzeć się wrażeniu, że była to celowa gra polityczna, wspierająca rozwój ekspansji politycznej Litwy najmniejszym kosztem. W czasach Mendoga proces ten dopiero się rozpoczął. Zapoczątkował go syn pierwszego króla Litwy Wojsiełk. Prawdopodobnie był on synem Mendoga z pierwszego małżeństwa ${ }^{229}$. Po przyłączeniu do Litwy Rusi Czarnej został przez ojca osadzony w Nowogródku. Według świadectwa latopisu hipackiego sprawował tam okrutne rządy, tępiąc zapewne sympatie do Daniela, głównego wroga Mendoga ${ }^{280}$.

Sytuacja zmieniła się dopiero około r. 1254, kiedy Daniel zawarł z Mendogiem porozumienie w Chełmie. Wtedy to córka Mendoga, a siostra Wojsiełka została poślubiona Szwarnowi Daniłowiczowi. Daniel uznał zwierzchnictwo Mendoga nad Rusią Czarną, wobec tego Wojsiełk w imieniu swoim i Mendoga odstąpił niefortunnemu synowi Daniela Romanowi Nowogródek, Wołkowysk, Słonim i resztę grodów czarnoruskich, sam zaś przyjął chrzest w Nowogródku ${ }^{231}$. H. Paszkiewicz uważał, że „,chrzest Wojsiełka był koniecznym uzupełnieniem dzieła Mendogowego, miał zabezpieczyć trwałość osiągniętych [na Rusi] zdobyczy" ${ }^{232}$. Być może chrzest Wojsiełka odbył się z inicjatywy Mendoga i miał miejsce przed pokojem chełmskim w r. 1254, a po koronacji króla w 1252. W ten sposób zabezpieczał się Mendog przed buntem poddanej mu ludności ruskiej, która otrzymała prawosławnego księcia.

Nad chrześcijaństwem Wojsiełka wielokrotnie się w nauce zastanawiano. K. Chodynicki kwestionował szczerość tego nawrócenia ${ }^{233}$, natomiast H. Paszkiewicz właśnie w szczerości tego aktu dopatrywał sie istoty niesnasek między ojcem i synem ${ }^{234}$. Analiza wypadków politycznych skła-

228 H. P a s z kiewicz, jw., s. 96. Latopis hustyński pod r. 1246 donosi, jakoby sam Mendog przyjął wiarę chrześcijańską ,ot' Wostoka so mnogimi swoimi bojary" (PSRL II 341). Wiadomość ta brzmi nieprawdopodobnie wobec tego, co donosi o pogaństwie Mendoga latopis hipacki. To ostatnie źródło z pewnością o tak znamiennym fakcie poinformowałoby czytelnika, jaiko że posiada o Litwie dość dokładne wwiadomości. Latopis hustyński, źródło powstałe w XVI lub XVII w., zawiera wiele bałamutnych wiadomości; por. D. I. Myszko, Hustyńśkyj litopys jak istoryczne dżereło, „Ukraińskyj Istorycznyj Żurnał” 1971 nr 4 s. 73.

229 J. Latkowski, S. 372; N. I. J ermolowicz (Iz istorii..., s. 349) twierdzi, że Wojsiełk miał witedy 31 lat (ur. w 1223 r.), a matką jego była księżniczka twerska, przy czym powołuje się na: Żiwopisnaja Rossija, M. t. III, 1882, s. 76.

230 PSRL II $858-859$.

231 Tamże, $830-831,859$.

${ }^{282} \mathrm{H}$. Paszkiewicz, jw., s. 96.

${ }^{233} \mathrm{~K} . \mathrm{C}$ hodynicki, jw., s. 251 .

234 H. P a szkiewicz, jw., s. 96. 
nia do przyznania racji temu drugiemu historykowi. Akt Wojsiełka był niewątpliwie szczery. W przeciwnym razie trudna byłaby do wyjaśnienia ta uporczywa chęć pozostania mnichem. K. Chodynicki tłumaczył ją jako sposób przeczekania niepomyślnej dla niego koniunktury politycznej na Litwie ${ }^{235}$. Jest to jednak tłumaczenie niesłuszne. Wojsiełk wcale nie musiał zostawać mnichem po to, by w monasterze z ukrycia, ,śledzić bieg wypadków" i marzyć o tronie litewskim, ukrywając się w dodatku na terenie władztwa swego ojca. Wystarczy przytoczyć tu chociażby przykłady Towtywiła, Dowmunta czy Herdena, by zrozumieć całą sztuczność tej argumentacji ${ }^{286}$. Władza Mendoga musiałaby być bardzo ograniczona, skoro na terenie państwa litewskiego ukrywałby się czatujący na jego zgubę syn.

Wojsiełk niewątpliwie szczerze przyjął chrzest w Cerkwii i nie ograniczył się do tego tylko aktu. Zapragnął bowiem pozostać mnichem, by odpokutować za swoje okrutne czyny. Czy poganin mógłby w ogóle

${ }^{285} \mathrm{~K}$. Chodynicki, jw., s. 252.

236 Towtywił, jako zbieg z Litwy, przebywał u Daniela do roku 1254. Potem pogodziwszy się z Mendogiem wraca na Litwę, by w 1262 r. wystąpić jako książę Polocka (NPL s. 83). Natomiast syn Towtywiła Konstantyn wstąpił w związki małżeńskie z córką Aleksandra Newskiego i otrzymał od teścia Witebsk (W. T. Plas zuto, Obrazowanie..., s. 385). Po zamordowaniu Towtywiła przez Trojnata w trakcie walki o spadek po Mendogu, Konstantyn panował jakiś czas w Połocku, po czym uciekł przed Trojnatem do Nowogrodu (NPL s. 83) i uznał swą zawisłość od ,króla Nowogrodu” (HU I nr 1093, s. 377-379; r. 1292). Syn Towtywiła, podobnie jak ojciec, był katolikiem. W okresie jego rządów w Połocku dostrzega się pewien wplyw katolicyzmu. Abp ryski twierdził później, że otrzymał od księcia połockiego darowiznę całej ziemi (Vetera Monumenta I nr 204). Książę Konstantyn miał posiadać w księstwie połockim biskupów i kler łaciński, a część mieszkańców miała przyjąć katolicyzm (LUB II nr 638, art. XIV; Reg. $\mathrm{nr} 737$ s. 31). Wł. Abrah am (Powstanie organizacyi..., s. 150) uważał, że w tym czasie biskupstwo zelońskie (później semigalskie) rozciągnęło swą działalność na Połock. Wiemy jednak, że biskupstwo semigalskie zostało w r. 1251 inkorporowane do diecezji ryskiej (LUB I nr 219; PrUB I nr 241). Zatem jeśli któraś z diecezji taką zwierzchność rozciągnęła, to tylko diecezja ryska. Z bulli Urbana IV (1264) dowiadujemy się, że Konstantyn podarował Zakonowi pewne ziemie (,lacum Luban ordo tenet et possidet virtute castri, vulgariter dicti Rosyten, quod castrum inclitus rex Constantinus de Ploske Ordini dedit pleno iure". LUB I nr 380; LUB V nr 2884, p. 217). Tę darowiznę Konstantyna potwierdził, a nawet rozszerzył o Letgalię następca Konstantyma na księstwie połockim z ramienia Wojsiełka - Herden. W zamian Zakon zobowiązal się nie napadać na księstwo połockie i nie naruszać swobody handlu (RLA nr 25). Syn Herdena, wzięty do niewoli przez Pskowian Dowmunta, został pod imieniem Andrzej biskupem twerskim (Troickaja letopis. Rekonstrukcja M. A. Prisjełkowa, Moskwa-Leningrad 1950, s. 344-345). Po Herdenie mógł znowu panować w Polocku syn Towtywiła Konstantyn (W. T. P a s z u to, Obrazowanie..., s. 391-392). Natomiast Dowmunt nalszczański, zabójca Mendoga, z 300 Litwinami uszedł w r. 1265 do Pskowa, gdzie przyjął chrzest i został księciem (NPL s. 85; PSRL IV 180). Widzimy zatem, że żaden $\mathrm{z}$ wychodźców litewskich nie czekał sprzyjających akoliczności w klasztorze. N. I. J e r mołow i c z (Iz istorii..., s. 351), odwracając dotychczasowe poglądy na stosunki litewsko-ruskie, dowodzi, że Wojsiełk zmuszony do oddania Rusi Czarnej Romanowi, nie porzucił myśli połączenia Rusi Czarnej z Litwą, co godziło tak w Daniela, jak i Mendoga. Uważając zaś pogaństwo Litwy za główną przeszkodę do tego zjednoczenia, wstąpił do klasztoru, by pozyskać tam kadry dla przyszłej chrystianizacji Litwy. Dowodzenie to zupełnie nie przekonuje i stoi w sprzeczności $z$ danymi latopisu hipackiego. 
samodzielnie zdobyć się na tego rodzaju decyzję? Musiał on otrzymać pewne pouczenia $w$ zakresie spraw religijnych, a pouczenia te należy przypisać jakiemuś ośrodkowi monastycznemu w Nowogródku. Tylko mnisi mogli zaszczepić w neoficie przekonanie o wyższości życia monastycznego. Pogląd ten popiera poniekąd charakter jednej z części latopisu hipackiego, którą W. T. Paszuto określał mianem „latopisu litewskiego” ${ }^{287}$. Podaje ona wiele danych historycznych dotyczących Litwy, różni się natomiast wyraźnie od pozostałej części latopisu. H. Łowmiański uważał, że autora opowieści należy szukać w otoczeniu Wojsiełka, wśród mnichów jego klasztoru nad Niemnem ${ }^{238}$. Nie można jednak wykluczyć, że autorem tego tekstu był jeden z mnichów jakiegoś klasztoru w Nowogródku, którego dziełem była konwersja Wojsiełka ${ }^{239}$.

Po pokoju chełmskim Wojsiełk odsunął się od polityki. Przebywał najpierw na dworze Daniela ${ }^{240}$. Tam zetknął się $z$ kwitnącym życiem cerkiewnym. Jego zainteresowania były wyraźnie ukierunkowane. O żadnym politycznym celu pobytu Wojsiełka na Rusi Halicko-Włodzimierskiej latopis nie wspomina. Wojsiełk przyjął szatę mnicha w klasztorze św. Grzegorza w Połoninie, gdzie miał przebywać przez trzy lata. Później zapragnął udać się na górę Atos. Mimo błogosławieństwa ihumena Grzegorza, do celu nie dotarł, ,zanie miatież byst wielik togda w tych zemljach" ${ }^{241}$. W tym czasie stosunki litewsko-ruskie uległy pogorszeniu. Ruś Czarna znalazła się znowu w bezpośrednim władaniu Litwy. Stąd Wojsiełk nie wrócił do klasztoru w Połoninie, ale do Nowogródka, gdzie, być może, został zmuszony przez ojca do objęcia rządów ${ }^{242}$.

W r. 1258 Litwę spustoszyła tatarsko-ruska wyprawa Burundaja. W tym czasie Daniel uderzył na Ruś Czarną i zdobył Wołkowysk, usiłując schwytać ,,woroga swojego Wyszełka i Tewtywiła" ${ }^{243}$. Być może, już wtedy Wojsiełk i Towtywił władali z ramienia Mendoga na Rusi Czarnej.

Zapewne po wyprawie tatarskiej Wojsiełk odsunął się znowu od życia politycznego, osiadając w wybudowanym przez siebie klasztorze ,mieżi Lit'woju a Nowymgorodkom", gdzie rozpoczął życie mnisze ${ }^{244}$. Latopis opowiada, że ten jego sposób życia bardzo nie podobał się Mendogowi, który

237 W. T. Paszuto, Oczerki..., s. 113-121.

238 H. É w miańs ki, Uwagi o genezie..., s. 131.

289 W. T. P a szuto (Oczerki..., s. 119-121) uważał, że zainteresowanie autora tej części latopisu pogaństwem litewskim, świadczy 0 ewentualnej propagandzie prawosławia na Litwę. 859).

240 Trzymał tam do chrztu syna księcia Lwa Daniłowicza - Jerzego (PSRL II 241 Tamże.

242 J. Latkowski (jw., s. 377) przypuszczał, że Wojsiełk wrócił na Litwę krótko przed napaścią Tatarów.

243 PSRL II 847.

244 PSRL II 859. J. Latkow k k (jw., s. 405) umiejscawial ten fakt w roku 1259; N. I. Jermołowicz (jw., s. 351), zgodnie ze swą lokalizacją Litwy latopisu hipackiego, umiejscawia ten klasztor w Eawryszewie. 
chciał, by Wojsiełk przyjął ,kniażenie swoje” ${ }^{245}$, czyli Mendog, wbrew temu, co twierdził Chodynicki ${ }^{246}$, wcale nie chciał pozbawiać syna władzy. To Wojsiełk nie chciał tej władzy, chciał być mnichem. Ale synowi króla nie łatwo było odsunąc się od spraw politycznych. W $1263 \mathrm{r}$. Mendog wraz z dwoma synami, Ruklem i Repekiem, został zamordowany przez Dowmunta nalszczańskiego, który miał osobiste powody do nienawiści ${ }^{\mathbf{2 4 7}}$. Władzę na Litwie objął Trojnat, któremu udało się usunąć pretendentów do władzy. Pozostał tylko Wojsiełk, wprawdzie bez aspiracji politycznych, ale jego osoba mogła być zawsze wykorzystana. Zresztą czy Trojnat mógł być pewien przekonań Wojsiełka? I Wojsiełk to zrozumiał, ratując się ucieczką do Pińska ${ }^{248}$. Sam Trojnat po krótkich rządach został zamordowany przez kilku dworzan Mendoga, działających niewątpliwie $\mathrm{z}$ inspiracji Wojsiełka ${ }^{249}$. W mnichu-neoficie odezwały się pogańskie obyczaje zobowiązujące go, jako ostatniego z rodu, do zemsty na zabójcach krewnych. Wojsiełk, acz niechętnie, porzucił szaty mnicha i przy pomocy posiłków ruskich z Pińska i Nowogródka zawładnął Litwą ${ }^{250}$.

Po odzyskaniu władzy wypuścił Wojsiełk chrześcijan uwięzionych jeszcze przez Mendoga, zapewne także Konrada II mazowieckiego ${ }^{251}$. W stosunku do winnych buntu i śmierci ojca zastosował metodę okrucieństwa i terroru. Mordercy Mendoga Dowmuntowi udało się zbiec do Pskowa, gdzie z całą rodziną i drużyną ochrzczony (jako Timofiej), został księciem pskowskim, walczącym później z Litwą ${ }^{252}$.

Zwolennicy Mendoga przyjęli Wojsiełka z radością. Ten jednak sprawuje rządy z wyraźną niechęcią, ulegając stopniowo radom Szwarna i Wasylka. Po jakimś czasie ponownie odsunął się od świata i wstąpił do klasztoru w Ugrowsku, władzę na Litwie przekazawszy Szwarnowi ${ }^{258}$. Był to

245 NPL s. 284; PSRL II 859: ,otec że jego Mindog' ukariwaszet'sja jemu po jego żit'ju, on' [Wojsiełk] że otca swojego nielubowaszet' wielmi".

246 K. C hodynicki, jw., s. 251.

247 Zestawienie źródeł w: Regesta Lithuaniae, nr 422. O zabójstwie Towtywiła i objęciu rządów przez Trojnata mówi latopiis hipacki (PSRL II 861). Mendog po śmierci swej żony Marty sprowadził podstępnie na pogrzeb jej siostrę, żonę Dowmunta, po czym pojął ją za żonę, oświadczając jej, że taka była wola jej zmarłej siostry (PSRL II 859-860).

248 PSRL II 860. K. C hodyni cki (jw., s. 252) uważał, że Wojsiełk zamieszany był w spisek na życie ojca, opierając się na bałamutnej notatce Rocznika kapitulnego krakowskiego (MPH s.n. V s. 91), która przypisywała Wojsiełkowi i Towtywiłowi (który już nie żył) udział w zabójstwie Trojnata.

249 PSRL II 861. Zestawienie źródeł w: Regesta Lithuaniae, nr 434.

250 PSRL II 861; Regesta Lithuaniae, nr 435.

251 LR s. 164 (ok. 1264 r.); PSRL II 862-863. O dłuższym pobycie w niewoli litewskiej mówi dokument tegoż księcia z 1285 r., nadający kościołowi płockiemu wieś Rafałów (CDMG nr 36). Por. H. Pa s z kiewicz, jw., s. 102 p. 1.

252 NPL s. 85; W. T. P a s zuto, Obrazowanie..., s. 386.

${ }^{253}$ PSRL II 867. N. I. Jermołowicz (jw., s. 353) przypisuje Wojsielkowi rolę jednoczyciela ziem pińskiej, nowogródzkiej i litewskiej. Natomiast innych ziem litewskich nie mógł on według autora zdobyć, dlatego zmuszony był zawrzeć sojusz z książętami halicko-wołyńskimi, uznając swą zawisłość od nich. Z ich to pomocą 
najlepszy moment do chrystianizacji Litwy w obrządku wschodnim. Brak źródeł nie pozwala nam stwierdzić, czy w tym kierunku poczyniono jakieś starania. Jeśli tak, to ich żywot nie był długi wobec krótkotrwałych rządów Szwarna ${ }^{254}$. Sam Wojsiełk został zamordowany przez Lwa, syna Daniela, zazdrosnego o przekazanie władzy na Litwie Szwarnowi. Stało się to na Wielkanoc roku 1267 we Włodzimierzu wołyńskim. Ciało Wojsiełka spoczęło w tym grodzie ${ }^{255}$.

Litwa nie została schrystianizowana przez Kościół wschodni, mimo iż z tą gałęzią chrześcijaństwa łączyło ją więcej niż z gałęzią zachodnią. Zaważyły na tym głównie wydarzenia polityczne. Słabość Rusi i jej uległość Tatarom i Litwinom mogły czynić z prawosławia religię ludności poddanej. Poza tym, przyjęcie obrządku wschodniego nie ocaliłoby Litwy przed podbojem krzyżackim, a cel ten miał głównie na oku Władysław Jagiełło, zobowiązując się w Krewie do inkorporacji Litwy do Korony polskiej.

\section{KSIĄŻĘTA POLSCY A CHRYSTIANIZACJA LITWY}

W XIII w. żadne $\mathrm{z}$ księstw polskich, prócz księstwa mazowieckiego, nie sąsiadowało $\mathrm{z}$ Litwą, a i to ostatnie sąsiedztwo było pośrednie, poprzez Ruś Czarną, świeżo państwu litewskiemu podporządkowaną. Poza tym od Litwy księstwa polskie były oddzielone przez ziemie jaćwięskie oraz Ruś Halicko-Włodzimierską.

Pomimo oddalenia, Litwini wnieśli swój wkład w życie polityczne książąt polskich. Przymierze zawarte przez Litwinów i Żmudzinów z Romanowiczami w r. 1219 skierowane było przeciw Leszkowi Białemu, którego następnie ,litewskie wojowanie” skłoniło do zawarcia pokoju w r. $1220^{256}$. Konrad mazowiecki, zaangażowany w walki o tron krakowski, często korzystał z posiłków pruskich, jaćwięskich i litewskich ${ }^{257}$. Przypuszcza się, że Konrad werbował oddziały litewskie za pośrednictwem jaćwięskim ${ }^{258}$.

Jaćwież w XIII w. zdołała stworzyć dość ścisłą federację plemienną. Zatarcie podziałów plemiennych zdaje się dowodzić, że prześcignęła ona w rozwoju państwowym pozostałe zespoły plemion pruskich, osiągając

miał zdobyć Dziawołtwę i Nalszczany oraz podporządkować sobie Polock. W zjednoczeniu tych ziem autor dopatruje się początku Wielkiego Księstwa Litewskiego. ${ }^{254}$ Latopis hipacki mówi o tym lakonicznie, że panował on lat „niemnogo", po czym ,prestawisja".

${ }^{255}$ Wojsiełk został zamordowany w klasztorze św. Michała we Włodzimierzu i tam tė̇, w cerkwii klasztornej, został pochowany (PSRL II 868).

${ }^{256}$ PSRL II 736, 739; MPH III 132; O. H a le cki, Dzieje unii jagiellońskiej,

t. 1. Kraków 1919 , s. 16 .

${ }_{257}$ MPH II 556, 564, 838; III, 49, 168-169.

258 Por. J. P ow ierski, Rola Jaćwieży..., s. 91. 
stan organizacyjny zbliżony do Żmudzi, analogiczny do wcześniejszego poziomu organizacyjnego Auksztoty. Istnieją dowody na stosunkowo silną pozycję Jaćwieży pośród zespołu plemion pruskich. Militarna siła federacji jaćwięskiej wobec zagrożenia krzyżackiego umożliwiła jej wywieranie dużego wpływu na życie polityczne Prusów, a może nawet doprowadziła do podporządkowania jej Skalowów i Nadrowów ${ }^{259}$. Przypuszcza się także, że Jaćwież odegrała wielką rolę w skoordynowaniu działań bałtyjskich przeciw misjom chrystianizacyjnym i ekspansji feudalnej po r. 1217 za pośrednictwem ogólnopruskiego wiecu w Romowe, gdzie zajmowała dominująca pozycję. To samo dotyczy roli Jaćwieży w I powstaniu pruskim ${ }^{260}$.

Procesami zachodzącymi w krajach bałtyjskich żywo interesowali się Litwini, usiłujący zapewne stworzyć ogólnobałtyjską federację. Jednak wobec wielokierunkowości ekspansji Litwy, plany te nie były realizowane konsekwentnie ${ }^{261}$. W każdym razie Jaćwież jeszcze w r. 1238 nie podporządkowała się Mendogowi i w ogóle Litwie, chociaż znane są przykłady wcześniejszej współpracy litewsko-jaćwięskiej ${ }^{262}$. Były to jednak sojusze zawierane w obliczu wspólnych wypraw łupieskich, stanowiących najlepszą i najłatwiejszą drogę do szybkiego bogacenia się grupy nobilów plemiennych i umożliwiających im zdobycie niewolników dla własnej gospodarki dworskiej.

Wcześniejsze, tradycyjne już wpływy na Jaćwież wywierało księstwo mazowieckie, bezpośrednio z nią sąsiadujące. W latach 1239-1242, wobec groźby agresji krzyżackiej, część Jaćwięgów, a mianowicie Połekszanie, weszła w pewien rodzaj zależności od Konrada, biorąc udział w jego wyprawach na Małopolskę. W połekszańskim Rajgrodzie spotykamy się w tym czasie z rycerzami noszącymi chrześcijańskie imiona. Dowodzi to wpływów mazowieckich w samym centrum Jaćwieży, jako że Połekszanie stanowili rdzeń całej konfederacji plemiennej ${ }^{268}$.

Jeszcze w maju 1243 r. Jaćwięgowie wraz z Litwinami brali udział w niefortunnej dla Konrada bitwie pod Suchodołem, ale już na początku

${ }^{259}$ Już w XIII w. Jaćwięgowie przyczynili się do rozbicia Galindów (Dusburg, s. 52); J. Powierski, Rola..., s. 88-90.

260 J. P owierski, Rola..., s. 92; por. też Ł. Okulicz-Kozaryn, Życie codzienne Prusów i Jaćwięgów w wiekach średnich (IX-XIII w.) Warszawa 1983; M. Gimbutas, Die Balten, München-Berlin 1983.

${ }^{261}$ R. Wróblewski, Problem jaćwieski..., s. 7; J. Ka miński, Jaćwież, terytorium, ludność, stosunki gospodarcze $i$ społeczne, Łódź 1953, s. 141-142; J. Powierski, Rola..., s. 90.

262 W r. 1238 Daniel wyprawił się na Jaćwięgów, a Mendog z jego poduszczenia napadł na Konrada mazowieckiego (PSRL II 776 n.), zatem Litwa nie sprzeciwiała się ekspansji ruskiej w kierunku Jaćwieży; por. J. Powierski, Kazimierz kujawski..., s. 12; PSRL II 721.

263 CDMG nr 407, 450; MPH s.n. VIII s. 83, 89; J. P owierski, Rola..., s. 89 (p. 8), 93. 
czerwca posiłkują Prusów w ziemi chełmińskiej ${ }^{264}$. Wejście Litwinów i Jaćwięgów do koalicji antykrzyżackiej w latach 1243/4 i sukcesy odniesione nad Krzyżakami, wpłynęły na zerwanie związków zależności Jaćwieży od Konrada ${ }^{265}$. Stanowisko Jaćwieży w koalicji antykrzyżackiej wzrosło natomiast znacznie, doprowadzając zapewne do antagonizmów $\mathrm{z}$ Litwą, pretendującą do zwierzchnictwa nad wszystkimi ludami bałtyjskimi, a tym samym i nad Jaćwięgami. Pewien rozdźwięk w obozie bałtyjskim daje się zaobserwować już w r. 1246, gdy tylko sami Litwini posiłkują Konrada w wyprawie na Małopolskę. Trochę wcześniej, zimą 1245/6, Konrad i Wasylko podjęli wspólną wyprawę na Jaćwież, która jednak nie powiodła się z powodu wielkich zasp śnieżnych ${ }^{266}$. J. Powierski doszukuje się nawet istnienia porozumienia litewsko-mazowieckiego, przewidującego podział Jaćwieży, która - według tego autora - jako siła konserwatywna, przeciwdziałała wpływom Mendoga wśród ludów bałtyjskich ${ }^{267}$. Nie negując elementów silnego jeszcze konserwatyzmu plemiennego wśród Jaćwięgów (podobnie i wśród Żmudzinów), nie można, wobec wcześniejszych uwag, przejść obojętnie nad aspiracjami samej Jaćwieży $w$ trakcie powstania pruskiego, a także i później. W każdym razie niechęć Jaćwięgów do Mendoga zrodziła się już około 1246 r. Stąd bardziej zrozumiały staje się ich udział w antymendogowej koalicji. Oczywiście nie należy zapominać także o aspektach finansowych całej tej kampanii.

Po śmierci Konrada mazowieckiego kontynuatorem bałtyjskiej polityki ojca miał być najstarszy Konradowic - Bolesław, książę mazowiecki, ale jego choroba i rychła śmierć zniweczyły te plany. Dlatego rolę jego przejął kolejny według wieku syn Konrada Kazimierz ${ }^{268}$. Przez wiele lat jako książę kujawski aktywnie współdziałał on z Krzyżakami, biorąc udział w walkach ze Swiętopełkiem pomorskim i popierającymi go powstańcami pruskimi. W czasie powstania pruskiego był Kazimierz dla Krzyżaków sojusznikiem bardzo cennym. Przez ziemie księcia ciągnęli bowiem z Zachodu krzyżowcy, posiłkujący rycerzy zakonnych. Zresztą

264 Dusburg, s. 73-74; Długosz VII s. 67; J. P owierski, Kazimierz kujawski..., s. 14.

265 Jaćwięgowie i Litwini dopiero $w$ latach $1243 / 4$ włączyli się do powstania pruskiego. Jednocześnie rycerze o chrześcijańskich imionach wycofali się z jaćwięskiego Rajgrodu na Mazowsze (CDMG nr 450); por. J. P owierski, Rola..., s. $93-94$.

260 PSRL II 808.

${ }^{267}$ J. P ow ierski, Rola..., s. 94-95. Wiadomość latopisu hustyńskiego o walkach Mendoga (popieranego przez Daniela $\mathrm{z}$ Jaćwięgami brzmi prawdopodobnie (PSRL II 341). Wiadomości zaczerpnięte $\mathrm{z}$ tego źródła należy jednak przyjmować z dużą ostrożnością; por. P. I. M y s z o, jw., s. 73; M. M. Tichomirow, Istocznikowedenie istorii SSSR, Moskwa 1962, s. 353-354.

268 J. K a r was ińska, Sąsiedztwo kujawsko-krzyżackie..., s. 14-15. 
w walkach tych brał udział osobiście sam książę, skłócony z księciem pomorskim ${ }^{268}$.

Krzyżacy $\mathrm{w}$ tym czasie byli jeszcze zainteresowani sojuszem $\mathrm{z}$ księciem i, aby go z sobą bardziej związać, landmistrz Poppo za zgodą wielkiego mistrza Henryka von Hohenlohe nadał mu połowę krzyżackiej części ziemi lubawskiej ${ }^{270}$. W razie jej otrzymania zdobyłby sobie Kazimierz podstawę terytorialną do ekspansji w kierunku Prus. Zapewne także, jako najstarszy Konradowic, rościł sobie Kazimierz pretensje do zwierzchnictwa nad młodszym bratem Siemowitem (księciem mazowieckim po Bolesławie), szczególnie w dziedzinie polityki zewnętrznej ${ }^{271}$.

Siemowit jednakże, w zakresie polityki bałtyjskiej, silnie związał swe plany z książętami halicko-wołyńskimi, Danielem i Wasylkiem, za namową których, według latopisu hipackiego, Bolesław przekazał mu swe księstwo ${ }^{272}$. Książęta halicko-wołyńscy, a zwłaszcza Daniel, po odzyskaniu całego spadku po ojcu, energicznie przystąpili do realizacji planów podboju Jaćwieży ${ }^{273}$. W 1246 r. wyprawę przeciw Jaćwięgom podjął wespół z Konradem Wasylko ${ }^{274}$. W r. 1247 sami Rusini (być może w sojuszu z Litwą) prowadzą z nimi walkę, w czasie której ginie Skomand starszy ${ }^{275}$. Daniel bardzo prężnie starał się o podporządkowanie Jaćwięgów Rusi, wyprzedzając w tej polityce książąt polskich.

$\mathrm{Na}$ początku r. 1247 do Lionu udało się poselstwo ruskie, złożone z ihumena z Ugrowska i dwóch dominikanów. Rusini za cenę pomocy przeciw Tatarom uznali zwierzchnictwo kościelne Stolicy Apostolskiej. 27 sierpnia 1247 r. papież wystawił dla „królów Rusi”, Daniela i Wasylka szereg przywilejów i koncesji. Innocenty IV pozwolił Rusinom zachować zwyczaje Kościoła ruskiego, nie sprzeciwiające się wierze Kościoła rzymskiego ${ }^{276}$. Ponadto na prośbę Daniela i Wasylka udzielił im prawa odebrania siłą wszystkich ziem, „que alii Reges, qui in Ecclesia devotione non permanent, contra iustitiam detinent" ${ }^{277}$. Można się domyślać, że koncesja

269 Tamże, s. 14, 24-31; B. W ł o d a r ski, Rywalizacja..., s. 15-27.

270 PrUB I nr 190. Już S. Kujot (Dzieje..., cz. 1 s. 730) zwrócił uwagę, że plan tej darowizny należy odnieść do roku 1246, ponieważ w dokumentach mówi się o zgodzie wielkiego mistrza.

${ }_{271}$ S. Kujot, Dzieje..., cz. 1 s. $791 ;$ H. Pas zkiewi cz, Z życia politycznego Mazowsza w XIII w., [w:] Księga ku czci O. Haleckiego, Warszawa 1935, s. 212.

272 PSRL II 788. Związki Daniela z Siemowitem zostały umocnione przez małżeństwo księcia mazowieckiego z córką Daniela Perejasławą. O. B a l z e r (Genealogia Piastów, Kraków 1895, s. 313) zawarcie małżeństwa odnosi do roku 1248.

${ }^{273}$ Stosunki polityczne na Rusi halicko-wołyńskiej znalazły swoje odzwierciedlenie w pracach W. T. Paszuto (Oczerki...) oraz B. Wlodarskiego (Polska $i$ Ruś...).Por też popularne opracowanie: M. F. Kotljar, Danyło Hatyćkyj, Kyiw 1979.

${ }_{274}$ PSRL II 808. B. Włodarski, Problem jaćwięski $w$ stosunkach polsko-ruskich, ZH 24 (1959) z. $2-3$ s. 30 n.

275 PSRL II 799.

276 DPRHUI I nr 20 (27 sierpień 1247 r.).

277 Tamże. 
ta dotyczyła głównie księstwa kijowskiego, znajdującego się we władaniu książąt włodzimiersko-suzdalskich, posiadających je $\mathrm{z}$ łaski Tatarów ${ }^{278}$. Inna bulla już wprost odnosi się do spraw bałtyjskich. Otóż papież zakazał w niej Krzyżakom i innym zakonnikom wkraczać bez pozwolenia książąt halicko-wołyńskich na tereny ich wpływów politycznych $\left(,,[\ldots]\right.$ in terris vestris acquisitis ac acquirendis") ${ }^{279}$. Koncesja ta odnosiła się z pewnością do Jaćwieży, do której pretendowała Ruś, a może i Litwy, chociaż to mniej prawdopodobne ${ }^{280}$. Innymi ziemiami Krzyżacy nie byli przecież na tym etapie zainteresowani. Dnia 12 września 1247 r. Innocenty IV wziął w opiekę Stolicy Apostolskiej Daniela, Wasylka, „Regna, familias, possesiones, et alia bona [...] que in presentiarum" posiadają, ,aut in futurum iustis modis" nabędą ${ }^{281}$.

Widzimy zatem, że sprawa unii była dość zaawansowana. Dla Rusinów stwarzała ona możliwość ochrony przed Tatarami, a także możliwość nabycia ziemi Jaćwięgów, która schizmatykom z pewnością nigdy nie zostałaby przyznana. J. Powierski dopatruje się w tych sukcesach dowodów współpracy rusko-małopolsko-węgierskiej. Jak widoć, Rusini byli w tym względzie bardzo samodzielni ${ }^{232}$.

Jednocześnie papież przyznał szereg przywilejów arcybiskupowi Albertowi, który już rok wcześniej (1246) otrzymał godność legata papieskiego na Rusi ${ }^{283}$. Wskutek oporu Krzyżaków nie mógł on jednak wyrwać się z Lubeki, gdzie tkwił jeszcze w lipcu 1247 r. ${ }^{284}$ Albert otrzymał prawo

${ }^{278}$ W. T. Paszuto, Oczerki..., s. $234-237$; J. Powierski, Kazimierz kujawski..., s. 40 .

279 DPRHUI I nr 21 (27 sierpień 1247 r.).

280 W 1 . A b r a h a m, Powstanie organizacji..., s. 126, 130.

281 DPRHUI I nr 25.

282 J. Powierski, Kazimierz kujawski..., s. 41. Bez wątpienia pertraktacje o unię ze Stolicą Apostolską toczyły się za pośrednictwem Węgier. Latopis hipacki podaje, że Węgrzy wysitraszyli się konszachtów Daniela z Tatarami (PSRL II 809). Po powrocie od Tatarów Daniel wysłał Beli IV swe uwagi (CDArp VII nr 107). W tym samym czasie toczyły się pertraktacje o małżeństwo między córką Beli IV Konstancją, a synem Daniela Lwem. Małopolska także zaangażowana była w te zabiegi, chociażby przez swe związki z Węgrami. Rycerstwo małopolskie posiłkowało wyprawę węgierską, usiłującą osadzić Rościsława na tronie halickim, w bitwie pod Jarosławiem w r. 1245 (PSRI II 800-805). Natomiast Romanowiczów posiłkowali Konrad i Litwini. Pod koniec lata Wasylko usiłował pogodzić książąt polskich w obliczu zagrożenia tatarskiego (B. Włodarski, Polska i Ruś..., s. 130-131). W czasie walk o Kraków w r. 1246 Rusini już nie posiłkowali Konrada, a do wyprawy na Jaćwież dał się Wasylko namówić bardzo niechętnie (tamże, s. 133, 170). W zabiegach o unię widzimy jednak przejawy dużej samodzielności Rusinów, którzy wiązali się z Zachodem, aczkolwiek ze strony Tatarów w tym okresie nic im nie groziło, jako że Daniel otrzymał zatwierdzenie od Batego (W. T. Paszuto, Oczerki..., s. $236-237)$.

283 Innocenty IV rozszerzył legację arcybiskupa Alberta na Ruś 3 maja 1246 r. (DPRHUI I nr 12, 13, 14, 15). We wrześniu 1246 r. spotykamy go w Lubece. Lubeczanie w porozumieniu z Krzyżakami uniemożliwili arcybiskupowi udanie się do Prus. Por. J. P ow ierski, Kazimierz kujawski s. 32.

284 PrUB I 2 nr 929; por. P. von Goetze, Albert Suerbeer..., s. 15 n. 
udzielania dyspens „,a defectu natalium” ${ }^{285}$, prawo konsekrowania biskupów na Rusi ${ }^{288}$ i prawo używania tam paliusza ${ }^{287}$. Papież polecał także Albertowi osobiście udać się na Ruś i przyjąć oficjalnie książąt ruskich do unii z Kościołem rzymskim ${ }^{288}$. Zatem na Ruś udał się Albert zapewne na początku $1248 \mathrm{r}$.

Tymczasem Daniel latem 1248 r. zorganizował wyprawę na Jaćwież. Wziął w niej udział Siemowit mazowiecki, odpłacając się książętom halicko-wołyńskim za życzliwość oraz mając prawdopodobnie widoki na własne korzyści. Posiłki przysłał też Bolesław Wstydliwy. Wyprawa zakończyła się dużym sukcesem ruskim. Wojska sprzymierzonych przeszły Narew i uwolniły wielu chrześcijan pozostających w niewoli jaćwięskiej ${ }^{289}$. Co więcej, rezultatem tej wyprawy było powołanie biskupstwa jaćwięskiego przez arcybiskupa Alberta. Na biskupa przeznaczył on dominikanina Henryka, tego, który wraz z Aleksym uczestniczył w poselstwie Daniela do Lionu ${ }^{200}$. Zatem Albert doznał wsparcia i łask przede wszystkim od Daniela. Jeden z jego doradców, dominikanin Henryk, został wyznaczony na biskupa jaćwięskiego. Dlatego musi tu upaść stary domysł S. Kujota, że arcybiskup Albert uzyskał tę pomoc od księcia Kazimierza i wraz z Henrykiem pracował w ziemi galindzkiej i jaćwięskiej ${ }^{291}$, na co nie ma żadnych dowodów. Zresztą Henryk miał być tylko

285 DPRHUI I nr 23.

286 Tamże, nr 24. Prawo wyświęcania biskupów na Rusi pochodzących z Zakonu dominikanów (!) przyznał papież Albertowi rok wcześniej, 3 maja 1246 r. (tamże, nr 15).

287 Tamże, $\mathrm{nr} 27$ (7 wrzesień 1247 r.).

288 Tamże, nr 26 (7 wrzesień 1247 r.). Piepież polecił mu, by „pers o nalite r ad partes illas [Ruś] accedens, si prefatus Rex in tam sancto proposito perseverans, tam ipse, quam Archiepiscopi (?) et Episcopi et alii magnates Regni sui, scismate qualibet penitus abiurato, promiserint et iuraverint se de cetero in unitate fidei, quam ecclesia Romana predicat et observat eiusdemque Romane Ecclesie devatione perpetuo permansuros eos auctoritate nostra et reconcilies, et tamquam speciales et devotos filios incorpores predicte Romane Ecclesie, que mater est omnium unitati". W ten pobyt Alberta na Rusi często powątpiewano (Wł. A braham, Powstanie..., s. 128; S. Z a jąc zkowski, Studia..., s. 60; W. T. Paszuto, Oczerki..., s. 252). Ale ponieważ papież nakazał mu osobiście udać się na Ruś i odebrać uroczystą przysięgę na wierność Sitolicy Apostolskiej a wiemy, że taką przysięgę Daniel złożył (,predicte Ecclesie obedientia, i u r a m e nto praestito promis isti involabiter observare": DPRHUI I nr 34), musimy przyjąc ten pobyt jako niewątpliwy.

289 PSRL II 810-813. B. Włodarski (Rywalizacja..., s. 35) datuje wyprawe na wiosnę 1248 r. (błota były nie zamarznięte). W innej pracy (Polska $i$ Ruś..., s. 173-174) datował ją na przełom 1248 r. Najbardziej prawdopodobne, że odbyła się ona wczesnym latem $1248 \mathrm{r}$. Latem Daniel zajęty był innymi sprawami. Planował on wyprawę przeciw cesarzowi wespół z królem węgierskim (tamże, s. 140). Na wiosnę 1249 r. arcybiskup Albert został już wygnany z Prus.

280 Wł. A h rah a m, Powstanie organizacji..., s. 129 (p. 1).

$291 \mathrm{~S} . \mathrm{Ku}$ jot, Dzieje..., cz. 1 s. 795. Podobne sądy wypowiedzieli: B. Włodarski, Rywalizacja..., s. 38; tenże, Polska $i$ Ruś..., s. 174; J. P owierski, Rola..., S. 97, K. Górski, Descriptiones Terrarum..., s. 12. Na związki misji jaćwięskiej z Danielem wskazywali już: A. Proch aska, Dwie koronacje, PH (1905) s. 202; H. Łow miański, Studia..., t. 2 s. 316. 
biskupem Jaćwieży. O Galindii w ogóle nie ma mowy. Zatem z wyprawy tej główne korzyści przypadły Danielowi. Siemowit i Bolesław nie zyskali zapewne niczego, prócz moralnej satysfakcji. Dlatego też Kazimierz nie był skłonny hołdować koncepcjom ruskim rozwiązania kwestii jaćwięskiej i do tego także starał się przekonać młodszego brata.

Albert nie zdążył wyświęcić Henryka, gdyż został z Prus wygnany przez rycerzy zakonnych, zapewne bardzo niezadowolonych z polityki arcybiskupa w ziemi Jaćwięgów. Arcybiskup tymczasem obłożył Krzyżaków klątwą, a Henryk starał się w Kurii o zgodę na konsekrację przez innego biskupa ${ }^{292}$. Znaczy to, że w r. 1249 misja jeszcze trwała, skoro Henryk domagał się święceń. Że nie była ona tylko epizodem, świadczy nowe źródło do spraw bałtyjskich, tzw. Descriptiones terrarum. Podaje ono że „na wschodzie zaś, w stronę Rusi, Jetwesya przylega. Tę z towarzyszem zacząłem chrzcić" ${ }^{293}$. W innym miejscu donosi o łatwym przyjmowaniu chrztu przez Jaćwież ${ }^{294}$. Według K. Górskiego, autorem opisu był biskup jaćwięski Henryk ${ }^{295}$. Jaćwięgowie zaś, podobnie jak Żmudzini, weszli do koalicji wrogiej Mendogowi, ale pozostawali pod wpływem Daniela. Dopiero w r. 1252 Mendog ich przekupił ${ }^{296}$. Zatem misja mogła w takiej postaci trwać spokojnie do r. 1252 (lub przynajmniej do 1250), skoro to biskup jaćwięski był obecny w czasie koronacji Mendoga ${ }^{297}$. Do tego czasu nie ma żadnych, ani polskich, ani ruskich wypraw na Jaćwież. Że biskup działał w oparciu o Ruś, o tym świadczy także określenie ludu Jaćwięgów podano $w$ suplice biskupa Henryka do Kurii, a powtórzone potem w bulli papieskiej. Użyta została nazwa ruska 'Jatwesonia', a nie 'Polexia' czy 'Sudawia', jak określali Jaćwież Polacy i Krzyżacy ${ }^{298}$. Domysł ten potwierdza poniekąd hipotezę K. Górskiego. Autor nowo odkrytego źródła (bp Henryk?) wyrażał się przychylnie o Kościele wschodnim. A przecież Henryk wraz z Aleksym mieli z hierarchią ruską ścisłe kontakty ${ }^{299}$. Stwierdzenie bulli papieskiej, że Henryk „una cum eo [abp. Albertem] pro negotio fidei et ecclesiae diligenter et fideliter laboravit" ${ }^{300}$, nie odnosi się do wspólnie przez nich prowadzonej misji wśród Jaćwięgów i Galin-

${ }^{292}$ Vetera Monumenta I nr 98; por. J. Powierski, Swrętopetk gdański..., S. 42 .

${ }^{298} \mathrm{~K}$. Górski, Descriptiones Terrarum..., s. 8.

294 Tamże, s. 9.

295 Tamże s. 11-13. J. O c h mańs ki (Nieznany autor..., s. 113) autorstwo przypisuje franciszkanowi Adolfowi, występującemu jako świadek na dokumencie donacyjnym dla Krzyżaków z lipca 1253 r. (LUB I nr 252).

297 K. G ór ski, jw., s. 9.

298 A. K a miński, Jaćwież..., s. $13-19$.

299 Wł. A b r a h a m, Powstanie organizacji..., s. 122, 125, 126. Dwaj dominikanie, Henryk i Aleksy, uczestniczyli zapewne w uroczystości zaprzysiężenia Daniela i Wasylka na wierność Stolicy Apostolskiej w obecności legata papieskiego arcybiskupa Alberta.

300 Vetera Monumenta I $\mathrm{nr} 98$. 
dów ${ }^{301}$, lecz wspólnych ich zabiegów wokół unii z Rzymem Kościoła ruskiego.

Na ruskie przywództwo tej wyprawy wskazuje także położenie geograficzne księstwa halicko-wołyńskiego i kujawsko-łęczyckiego. Kazimierz nie miał bezpośredniego dostępu do kraju Jaćwięgów, a ziemi lubawskiej jeszcze od Krzyżaków nie otrzymał ${ }^{302}$, poprzez którą dopiero miałby on dostęp do Prus i to do ziemi Galindów, zachodnich sąsiadów Jaćwięgów. Zatem książę nie miał żadnej możliwości wspierania misji jaćwięskiej. Mógł tylko wpływać na bieg wydarzeń pośrednio przez Siemowita, ale ten początkowo związał się z Danielem, swoim teściem, który wprost miał oświadczyć młodemu księciu: „Jako dobro widił jesi ot naju i izidi s nami na Jatwieze" ${ }^{303}$. Lachowie Siemowita źle się na wyprawie spisywali i latopisiec nie skąpił im cierpkich uwag ${ }^{304}$. Wszystko wskazuje zatem na to, że ani Siemowit ani Bolesław nie wynieśli z tej wyprawy żadnych korzyści ${ }^{305}$. Gdy w roku następnym formowała się antymendogowa koalicja i książęta ruscy wysłali posłów do książąt polskich z wezwaniem: „jako wremia jest' christ'janam' na poganiee jako sami imiejut rat' mieżi soboju", ci ostatni pomoc wprawdzie obiecali, lecz obietnicy nie dopelnili ${ }^{306}$.

W związku z tą sprawą wysuwa się zjazd Kazimierza, Bolesława i Siemowita odbyty $\mathrm{w}$ Inowłodzu w grudniu 1249 r., a poświęcony zapewne udziałowi książąt polskich $w$ walkach wewnętrznych na Litwie ${ }^{307}$. Być może, na zjeździe tym Kazimierzowi udało się przekonać Bolesława i Siemowita do zaniechania tej sprawy jako zupełnie dla ich interesów nieużytecznej. Możliwe też, że wszyscy zdecydowali się wziąć udział w mających nastąpić wydarzeniach, a później z nieznanych przyczyn się wycofali. Z tych dwóch ewentualności bardziej prawdopodobna jest pierwsza. Latopis hipacki bowiem podkreśla, że „Ljachowie że obieszczaszas” iść na pogan, ale swej obietnicy nie dotrzymali ${ }^{308}$.

Obietnica pomocy zbytnio nie dziwi. Bolesław Wstydliwy, związany w tym czasie z Romanowiczami, dobrze pamiętał o wspólnych litewsko-mazowieckich wyprawach przeciw niemu. Zapewne też nie darzył Mendoga dużą sympatią. Natomiast z Danielem łączyły go więzy polityczno-rodzinne. Żona Bolesława Wstydliwego była rodzoną siostrą Konstancji

301 Tak twierdził S. Ku jot, Dzieje..., cz. 1 s. $778 \mathrm{n}$.

302 Jego część przekazali mu Krzyżacy dopiero w 1257 r.; por. J. Kar wasiń$\mathrm{ska}$, jw., s. 48-50.

303 PSRL II 810.

304 Tamże.

305 B. Włodarski, Polska i Ruś..., s. 173.

306 PSRL II 815.

${ }^{307} \mathrm{~K}$. M M le c z yński, Dwa nieznane dokumenty jędrzejowskie $z$ XIII wieku, KH 38 (1924) s. 459; B. Wlodarski, Rywalizacja.., s. 38; J. Powierski, Swiętopetk gdański..., s. 42.

${ }_{308}$ PSRL II 815; J. Powierski, Swiętopetk gdański..., s. 42. 
(córki Beli IV), żony Lwa Daniłowicza (małżeństwo zawarte około r. 1246/7). Książę krakowski znajdował się zatem wraz z książętami ruskimi w obozie prowęgierskim. W lecie 1248 r. Daniel wyruszył na pomoc królowi węgierskiemu, który już wtedy aktywnie zaangażował się w walkę o dziedzictwo austriackie. Węgrzy też ułatwiali Danielowi kontakty z Kurią. Poprzez kontakty węgierskie zbliżył się Daniel do księcia krakowskiego ${ }^{309}$.

W walkach na Litwie pewne korzyści mogli widzieć dla siebie tak Bolesław, jak i Siemowit. Udziału w wyprawie jednak obaj nie wzięli. Ponieważ nie znamy prawie zupełnie sytuacji politycznej w Polsce w I poł. 1250 r., na temat braku udziału Polski wypowiedziano szereg domysłów. Stwierdzono, że Polacy nie chcieli zrywać dobrych stosunków z Mendogiem, gdyż nie chcieli narażać się papieżowi w czasie zabiegów o kanonizację św. Stanisława ${ }^{\mathbf{3 1 0}}$. Dodawano także, że porozumienie między Romanowiczami a Jaćwięgami i Żmudzinami zaskoczyło książąt polskich. Jednak w świetle faktów podanych powyżej o żadnym zaskoczeniu nie mogło być mowy. Jaćwięgowie pozostawali zapewne w pewnej zależności od Daniela. Wprawdzie latopis hipacki pisze o potrzebie pozyskiwania ich przez Wykinta (działającego w porozumieniu z Danielem), ale przecież sprawa dotyczyła ich udziału w walce na obcym terenie, a nie tylko o płacenie trybutu ${ }^{311}$. Podobnie nie można sugerować jakichś kłopotów ze strony Kurii, utrudniających starania o kanonizację św. Stanisława. W r. 1249 Kuria nie miała bowiem żadnych powodów, by popierać Mendoga, jeszcze poganina.

Mimo iż materiał źródłowy jest dla tego okresu fragmentaryczny, obserwujemy w latach 1250 -1253 załamanie się dobrych stosunków między Rusią halicko-wołyńską a książętami polskimi. W pierwszej połowie r.

${ }^{309}$ B. W łodarski, Polska i Ruś..., s. 133. Możliwa jest ruska dywersja w czasie litewsko-mazowieckiego najazdu na Małopolskę w $1246 \mathrm{r}$.

810 J. P owierski, Polityka battyjska..., s. 317. Autor ten (Świętopełk gdański..., s. 42) przyjmuje za prawdopodobną hipotezę O. Blalzera (Genealogia Piastów..., s. 304-307) o spokrewnieniu Konradowiców z przywódcą antymendogowej koalicji na Żmudzi, Wykintem. Domysł Balzera nie wytrzymuje jednak krytyki. Małżeństwo między Ludmiłą a Trojnatem miało być zawarte jeszcze za życia Konrada, w $1238 \mathrm{r}$. Tymczasem Trojnat pojawia się w źródłach dopiero u schyłku lat 50 XIII w. (Długosz, VII s. 151), czyli prawie po 20 latach od daty rzekomych zaślubin. Przedtem miał on przebywać na dworze Mendoga. S. Zajączkowski przypuszczał, że wyparł go ze Żmudzi Towtywił, czyli fakt ten milałby miejsce po śmierci Wykinta w $1252 \mathrm{r}$. Nie ma na to jednak żadnych dowodów. Imię Trojnata nie pojawia się ani razu w czasie walk koalicji z Mendogiem. Pojawia się on dopiero w r. 1258 jako człowiek prawdopodobnie młody. Nie wiemy, czy Trojnat był chrześcijaninem. Mógł nim być w latach pięćdziesiątych XIII w., ale z pewnością nie był nim w latach trzydziestych. Oddawanie córek za żony poganom, bez gwarancji ich konwersji nie było praktykowane. Dlatego przyjmowanie wątłej hipotezy Balzera, opartej na bałamutnych danych Kroniki Bychowca, musi byé traktowame co najmniej ostrożnie. Por. M. A. J u czas, Chronika Bychowca, [w:] Letopisi $i$ chroniki, Moskwa 1973 (1974) s. 220-231.

${ }^{311}$ PSRL II 815-816; J. P ow ierski, Polityka battyjska..., s. 317. 
1250 debatowano w Małopolsce wokół supliki w sprawie kanonizacji św. Stanisława ${ }^{312}$. 26 maja 1252 r. Innocenty IV polecił franciszkaninowi Jakubowi z Velletri, aby sprawdził, czy diecezja krakowska sąsiaduje z poganami i schizmatykami ruskimi. Kult nowego świętego miał bowiem wpłynąć na nawrócenie się tych krajów ${ }^{313}$. Bulle kanonizacyjne zostały sformułowane również $\mathrm{w}$ tym duchu, podkreślając, że kult nowego świętego przyczyni się do nawrócenia nie znających Boga (pogan) i pokonania herezji (schizmy) ${ }^{314}$. Trzeba podkreślić, że poza sąsiedztwem z Rusią Halicko-Włodzimierską Małopolska nie posiadała żadnych sąsiadów pogan i schizmatyków. Wiemy bowiem, że i Ruś pozostawała w tym czasie w stanie unii ze Stolicą Apostolską. Skąd zatem podobne stwierdzenia? Musiały widocznie zajść pewne fakty, które książąt polskich wrogo do Romanowiczów nastawiły.

Wszystko wskazuje na to, że antagonizm polsko-ruski zrodził się na tle ekspansji na ziemie jaćwięskie. W staraniach o ujarzmienie tych ziem Ruś była zdecydowanie górą. Dlatego książętom polskim udział $\mathrm{w}$ antymendogowej koalicji nie przyniósłby żadnych korzyści. Tym ostatnim chodziło bowiem głównie o podporządkowanie sobie przynajmniej części Jaćwieży. Udział zaś Jaćwięgów w walce $\mathrm{z}$ Mendogiem, i to po stronie Daniela, te polskie plany przekreślał ${ }^{315}$. Możliwe także, że Kazimierz rzeczywiście nie chciał psuć dobrych dotąd stosunków z Mendogiem i do tej polityki udało mu się przekonać tak Siemowita, jak i Bolesława Wstydliwego. Być może, stało się to na zjeździe tych książąt w Inowłodzu w grudniu 1249 r., gdzie mogła zapaść decyzja o niebraniu udziału w akcji przeciw Mendogowi.

Kazimierz kujawsko-łęczycki miał własne plany co do ziem bałtyjskich. Jak słusznie zauważono, był on twórcą planu podboju Jaćwieży i innych ludów pruskich tylko i wyłącznie siłami książąt polskich, bez uciekania

312 J. P owierski, Swiętopełk gdański..., s. $48-49$.

313 KDKK I nr 303.

314 Vetera Monumenta I $\mathrm{nr} 112$.

315 Możliwe, że już ok. 1249 r. stosunki między Danielem a Rzymem uległy zerwaniu. Długosz (VII s. 85) donosi o złym potraktowaniu przez Daniela legata Alberta. Wiadomość ta, podana pod tym rokiem, jest wątpliwa. Albert w r. 1249 przebywał poza terenem legacji, wygnany przez Krzyżaków. Do Prus przybył dopiero w 1250 r. Wzmianka Dlugosza znajduje natomiast poparcie w latopisie hipackim, który donosi o fiasku misji dwóch legatów papieskich u Daniela: biskupa bereńskiego i kamienieckiego (PSRL II $826-827$ ). Wł. A brah a m widział w nich biskupów werońskiego i kamińskiego (jw., s. 133, p. 2). Możliwe zatem, że informacja Długosza jest prawdziwa i miało to miejsce gdzieś w r. 1250. Rusini sprawe unii traktowali koniunkturalnie. W tym czasie wrócił z Cesarstwa nicejskiego dawny współpracownik Daniela (wysłany przezeń po święcenia w r. 1246), metropolita ruski Kirył. Pod wpływem pobytu w Bizancjum stał się przeciwnikiem unii. Po przyjeździe na Ruś udał się do Włodzimierza nad Klaźmą. Daniel zawiedziony współpracą z Kurią rozluźnił z nią swe kontakty aż do ponorwnego zagrożenia tatarskiego. Por. Wl. A braham, jw., s. 138-140; J. Umiński, Niebezpieczeństwo tatarskie $w$ pot. XIII $w$. a papież Innocenty IV, Lwów 1922, s. 103. 
się do pomocy ruskiej czy krzyżackiej ${ }^{316}$. Realizację tych planów uniemożliwił mu jednak niekorzystny dla niego zbieg okoliczności politycznych. W tym bowiem czasie pogorszyły się gwałtownie stosunki kujawsko-krzyżackie głównie na tle sąsiedzkich sporów o charakterze gospodarczym. Kazimierz rozpoczął nawet z Zakonem wojnę celną. Sprawy nie układały się jednak dla księcia pomyślnie. Brak poparcia ze strony innych książąt piastowskich i konflikt ze Swiętopełkiem pomorskim komplikowały prowadzenie konsekwentnej w tym względzie polityki ${ }^{\mathbf{3 1 7}}$. Dlatego 26 lipca 1252 r. doszło do ugody kujawsko-krzyżackiej, regulującej kwestie sporne. Krzyżacy $\mathrm{m}$. in. zobowiązali się dotrzymać przyrzeczenia co do ziemi lubawskiej, której jeszcze Kazimierzowi nie przekaza$\mathrm{li}^{318}$. Ugoda prawdopodobnie nie weszła w życie. W tym samym roku Kazimierz przygotował grunt pod misję pruską, która miała być prowadzona siłami polskimi ${ }^{319}$. Wiemy również, że pod koniec tego roku udało się Mendogowi odwieść od sojuszu z Danielem Jaćwięgów i Żmudzinów. Wywołało to gniew Daniela ${ }^{320}$, lecz nie mógł on od razu zareagować, gdyż Ruś stanęła ponownie wobec widma napaści tatarskiej, później zaś jako sojusznik króla węgierskiego, zaangażował się w walkę o spuściznę po Babenbergach austriackich ${ }^{\mathbf{3 2 1}}$.

Zatem sprawa Jaćwieży, zapewne nie w całości poddanej zwierzchnictwu Mendoga (a i to nie musiało być ścisłe), stała się znowu aktualna tym bardziej, że zapewne około tego czasu biskup Henryk musiał porzucić misję w tym kraju.

W r. 1252 Krzyżacy popadli w niełaskę Kurii na tle sporów w łonie Zakonu o orientację cesarską i papieską ${ }^{322}$. Ciekawe, że właśnie w tym roku Kazimierz kujawski ponownie zainteresował się misją pruską i jaćwięską. Akcję rozpoczął od uregulowania spraw spornych z episkopatem polskim, próbując zapewne zainteresować go sprawami północny$\mathrm{mi}^{\text {s23. }} 13$ lutego $1252 \mathrm{r}$. Innocenty IV nakazał arcybiskupowi Pełce, by ten wytyczył nie ustalone odcinki diecezji płockiej. Decyzja papieska była reakcją na suplikę biskupa płockiego Piotra i jego kapituły. Zabiegom

316 R. Wróblewski, Problem jaćwieski..., s. 8-9; B. Włodarski, Polska $i$ Ruś..., s. 177.

317 Szeroko o tym traktuje J. Powierski (Świętopełk gdański..., passim; tenże, Kazimierz kujawski, passim).

${ }^{318} \mathrm{PrUB} \mathrm{I} \mathrm{nr}$ 260. Dokument znany jest $\mathrm{z}$ transumptu biskupa warmińskiego Anzelma z $1253 \mathrm{r}$. (PrUB I nr 277).

${ }_{319}$ J. Karwasińska, jw., s. 36; B. Włodarski, Rywalizacja..., s. 38;

J. Powierski, Swiętopetk gdański..., s. 75 .

320 PSRL II 820.

${ }^{321}$ W. T. Paszuto, Oczerki..., s. 272, 282.

322 K. Forstreuter, Der Deutsche Orden..., s. 207. Dnia 18 listopada 1252 r. Innocenty IV udzielił nawet Norwegom koncesji na podbój Sambii (PommUB I 2 nr 933).

${ }_{323}^{3}$ J. P ow ierski, Polityka battyjska..., s. 319-320; tenże, Swiętopetk gdański..., s. $54-55,61-64,70-73$. 
krzyżackim należy przypisać włączenie do bulli klauzuli zastrzegającej, by $\mathrm{z}$ rozgraniczenia tego nie wynikły szkody dla Zakonu ${ }^{324}$. Z 29 września 1252 r. pochodzi przywilej Kazimierza odnoszący się do dóbr biskupstwa płockiego, położonych między Ruźcem i Branicą; świadczy o tym, że na pograniczu tym prowadzona była niegdyś akcja chrystianizacyjna, która w tym czasie została wznowiona ${ }^{325}$. Z tymi zabiegami należy połączyć działania polskiej delegacji w Kurii, załatwiającej tam sprawy związane nie tylko z kanonizacją św. Stanisława ${ }^{326}$.

$\mathrm{Na}$ początku r. 1253 Kazimierz i Bolesław Wstydliwy zwrócili się do Kurii w sprawie jaćwięskiej i pruskiej. 17 maja 1253 r. papież unieważnił wszystkie nadania, darowizny i zabory króla rzymskiego Wilhelma lub kogokolwiek innego, dokonane kosztem ziem polskich ${ }^{\mathbf{3} 2}$. Sprawa odnosiła się prawdopodobnie do sporu kujawsko-krzyżackiego o charakter nadania ziemi chełmińskiej ${ }^{328}$.

$\mathrm{Z}$ bull papieskich wystawionych 19 maja $1253 \mathrm{r}$. dowiadujemy się, że poganie z ziemi zwanej Polexia, przylegającej do posiadłości księcia Kazimierza, pragną nawrócić się i przejść pod opiekę księcia. Papież wyraził na to zgodę $\mathrm{z}$ tym zastrzeżeniem, że nie ma to $\mathrm{w}$ niczym naruszyć przywilejów danych Zakonowi, na mocy których przejmował on wszystkie ziemie zdobyte orężem. Ale ponieważ chodziło tu o ludność, która dobrowolnie chciała się nawrócić, papież nie wyrażał sprzeciwu ${ }^{829}$. Podobną bullę (ale bez określenia nazwy pogan) otrzymał także Bolesław Wstydliwy. W tym samym dniu wystawiono w kancelarii papieskiej bulle przeznaczone dla legata Opizona z Mezano, w których nakazano mu włączyć do sąsiednich diecezji polskich ziemię Galindów, oraz „omnes alias terras Paganorum, quas sibi possunt (Kazimierz i Bolesław) subiugare" ${ }^{330}$.

Należy zwrócić uwagę, że Kazimierz uzyskał prawo wcielenia do diecezji polskich terenu etnicznego Galindów oraz ziem, które ewentualnie zdobędzie. Prawo to mogło dotyczyć także terytorium Połekszan, ale wcale niekoniecznie. Bulla dotycząca ziemi Połekszan sankcjonowała tylko opiekę księcia nad pokojową działalnością misyjną oraz ewentualne zwierzchnictwo terytorialne. Połekszanie byli jednym z plemion jaćwięskich ${ }^{831}$.

324 PrUB I nr 256.

325 Dokumenty kujawsko-mazowieckie przeważnie $z$ XIII w., wyd. B. Ula nowski, [w:] Archiwum Komisji Historycznej, t. 4, Kraków 1888, nr 11.

${ }_{326}$ J. P ow ierski, Polityka battyjska..., s. $325-326$.

327 KDW I nr 314; Vetera Monumenta I nr 108.

328 J. P ow ie rski, Polityka battyjska..., s. 328.

329 Vetera Monumenta I nr 110.

330 Vetera Monumenta I nr 109.

${ }^{381} \mathrm{~W}$ sprawie plemienia Połekszan zob.: J. Nale pa, Połekszanie (Pollexiani) - plemię jaćwięskie u pótnocno-wschodnich granic polskich, RB 7 (1966). Ze starszej literatury por.: S. Z a jąc $\mathrm{zk}$ ow $\mathrm{ski}$, Problem Jaćwieży $w$ historiografii, ZTNT 19 (1953) s. 40; A. K a mińs ki, Jaćwież..., s. $19-25$. 
Kontakty z nobilami jaćwięskimi miał już Konrad. Nobilowie ci, ze względu na zagrożenie krzyżacko-litewskie zapewne chętnie widzieli opiekę książąt polskich, których ziemie z nimi nie graniczyły ${ }^{332}$. Kazimierz jednak ziemi Połekszan do diecezji płockiej przyłączyć nie mógł, jako że istniało już biskupstwo jaćwięskie, którego biskup przebywał na wygnaniu i żył jeszcze potem długo. Ale biskup Henryk związany był z Danielem, do którego zaufania nie miał z kolei Kazimierz.

Daniel zagrożony przez najazd tatarski znów był skłonny do odnowienia związków z Zachodem ${ }^{333}$; w r. 1253 zacieśnił związki z Węgrami i Bolesławem Wstydliwym wziąwszy aktywny udział $\mathrm{w}$ nowej fazie walk w Austrii ${ }^{344}$. Po powrocie z tej wyprawy podjął Daniel z posiłkami Siemowita i Bolesława odwetową wyprawę na Jaćwież, w toku której przyjął w Drohiczynie z rąk legata Opizona koronę królewską. Wyprawa jaćwięska przyniosła Danielowi sukces ${ }^{335}$. Dosięgła ona także terytorium plemiennego Połekszan, gdzie koncesje na pokojową pracę misyjną przyznał papież Kazimierzowi ${ }^{336}$. Wyprawa ta dowodzi, że książęta polscy Siemowit i Bolesław porzucili plany współdziałania z Kazimierzem i ulegli wpływom ruskim. W tym kontekście należy zwrócić uwagę na próby nobila jaćwięskiego Komata starającego się odwieść Daniela od tej wyprawy. J. Powierski przypuszcza, że mógł on powoływać się na przymierze $\mathrm{z}$ książętami polskimi Bolesławem i Kazimierzem ${ }^{337}$. Perswazje jednak na nic się nie zdały, co więcej, Daniel ruszył jeszcze dalej w głąb Jaćwieży. Wyprawa była zatem wymierzona także w pretensje Kazimierza (i poniekąd Bolesława) do kraju Jaćwięgów. Bolesław, nadal usposobiony wrogo głównie wobec Litwinów, związał swe plany bałtyjskie z planami Daniela. Być może, dokonało się to w trakcie wspólnej wyprawy na ziemie morawskie w czerwcu-lipcu $1253 \mathrm{r}$. Bolesław Wstydliwy, jako głowa stronnictwa węgierskiego w Polsce, zainteresowany był zapewne w jego konsolidacji. R. Wróblewski przypuszcza także, że wysuwając się na czoło w organizacji polskiej akcji misyjnej, chciał książę krakowski uwolnić się od dotkliwych świadczeń finansowych na rzecz

332 J. P owierski, Rola..., s. 98.

333 W. T. Paszuto, Oczerki..., s. 282.

334 B. Włodarski, Polska i Ruś..., s. 142-144. Za pośrednictwem Węgrów doszło do odnowienia stosunków między Danielem a Stolicą Apostolską (CDH IV 2 p. $144 ; 9$ maja 1252 r.).

335 PSRL II 826-828.

336 Tamże, 828: „Daniłu że korolewi iduszczu jemu po iezeru i widie pri berezie goru krasnu i grad' bywszi na niei imenem' Rai". Wyprawa zatem podeszła pod połekszański Rajgród, w którym w latach czterdziestych XIII w. utrzymywały się wpływy Konrada mazowieckiego (CDMG nr 450). Z opowieści latopisarza wynika, że Daniel nie zamierzał początkowo zapuszczać się $/ \mathrm{w}$ te strony, być może uzgodniwszy to poprzednio z Siemowitem i Bolesławem, którzy mogli jeszcze liczyć na realizację planów Kazimierza. Dopiero gdy Komat obiecał Rusinom „w rabotie byti”, a Lar chowie zapałali o to zawiścią i zaczęli ,prijati poganym", "i gdy o tym dowiedział się Daniel, rozkazał „wojewatiti zemlju Jatjaż'skuju”.

337 PSRL II, 828; J. P o w i e r s ki, Rola..., s. 99. 
krucjat, a także zyskać splendor w razie pomyślnego przeprowadzenia tej akcji ${ }^{338}$. Z Rusinami związał się także Siemowit, pragnąc usamodzielnić się od starszego brata. Rezultatem polskich starań o chrystianizację Bałtów (koncesje z maja 1253 r.) było przyśpieszenie krzyżackich poczynań wokół stworzenia biskupstwa litewskiego. Natomiast polsko-ruska wyprawa z r. 1253 wiąże się w jakiś sposób z konsekracją polsko-ruskiego kandydata na biskupstwo litewskie.

Późną jesienią 1253 r. we wsi Kozłów, sprzedanej w r. 1248 przez Siemowita biskupstwu poznańskiemu, arcybiskup gnieźnieński Pełka konsekrował dwóch biskupów. Jednym z nich był Piotr, elekt poznański, drugim dominikanin Wit, przeznaczony na biskupa Litwy ${ }^{339}$. O owym Wicie niestety wiele nie wiemy. $\mathrm{Z}$ pewnością nie był on biskupem jaćwięskim ${ }^{340}$. Źródła tytułują go zawsze „episcopus Littowiensis”, podczas gdy jednocześnie występuje w źródłach jako „episcopus Jatwesonie” dominikanin Henryk. Są pewne ślady, że Wit pracował pewien czas jako misjonarz na Litwie ${ }^{341}$.

W czyim zatem interesie leżało powołanie biskupstwa litewskiego związanego z archidiecezją gnieźnieńską? Prawdopodobnie Siemowita, Bolesława, ale zwłaszcza Daniela. Konsekracja biskupa Wita dokonała się w okresie, gdy stosunki między Rusią a Litwą były wrogie. U Daniela przebywali dwaj bratankowie Mendoga Towtywił i Edywid, którzy byli

${ }^{338}$ R. Wróblewski, Problem jaćwieski..., s. 4-5.

339 Rocznik kapituty poznańskiej, wyd. B. Kürbis, MPH s.n. VI s. 33: „Eodem anno [1253] frater Vitus de ordine Predicatorum fuit primus episcopus ordinatus in Littouiam et ibidem in Coslow una cum Petro est consecratus". Kronika wielkopolska, wyd. B. $\mathrm{K} \ddot{\mathrm{u}} \mathrm{r} \mathrm{b}$ is, MPH s.n. VIII 2 s. 100: „Anno vero predicto Petrus electus Poznamiensis et frater Vitus de ordine Predicatorum Lithwanorum primus episcopus, per venerandum Fulconem archiepiscopum Gnesmensen in episcopos fuerant consecrati". Wł. A bra ham (Powstanie organizacyi, s. 153, p. 2) próbował określić czas tej konsekracji na październik lub listopad $1253 \mathrm{r}$. W tym czasie mamy bowiem poświadczoną w źródłach obecność we Wrocławiu legata Opizo, o którego oparła się sprawa Piotra, elekta poznańskiego (S. S z c zur, Piotr, PSB t. 26 s. $365-366$ ). Te ustalenia można jeszcze uściślić w oparciu o przekaz kroniki wielkopolskiej z tego samego (1253) roku, donoszący o wielkiej powodzi w Polsce. Przy okazji kronikarz pisze o mszy celebrowanej w dniu Wszystkich Swiętych (1 XI). ,[...] Petro ele cto Posnaniensi episcopo cum suo capitulo consedente". Czyli 1 listopada Piotr był jeszcze elektem poznańskim. Zwrócił już na to uwagę G. S a p pok: Die Anfänge des Bistums Posen und die Reihe seiner Bischöfe von 968-1498, Leipzig 1937, s. 105. Obecność Opizona we Wrocławiu poświadczona jest 18 listopada (Grünhagen, $\mathrm{mr}$ 853). Witedy mógł on rozstrzygnąć pomyślnie sprawy obu konsekracji i wydać odpowiednie polecenie arcybiskupowi Pełce. Zatem konsekracja w Kozłowie musiała odbyć się pod koniec listopada $1253 \mathrm{r}$. W tym samym roku Opizo koronował Daniela w Drohiczynie. Należy podkreślić, że konsekracja Wita nie mogła odbyć się bez pozwolenia legata.

${ }_{340}$ S. Kujot, Dzieje..., cz. 1 s. $792 ;$ B. Włodarski, Rywalizacja..., s. 40; P. Kielar, Wit, [w:] Hagiografia polska, t. 2, Poznań 1972, s. 540-555.

${ }^{341}$ M. W is znie wski, Historia literatury polskiej, t. 2, s. 158 podał, że przed pożarem bibliateki dominikanów w Krakowie miał znajdować się tam traktat autorstwa Wita pt. De christianorum in Lithovia conditione deplorabili ad S. et B.P.D. Innocentium pp. IV. Później Wit doznawał kultu wespół ze św. Jackiem. por. Wł. A braham, jw., s. 154, p. 2; P. Kielar, jw., s. 540-554. 
już ochrzczeni. Usadowienie się Towtywiła na Litwie mogło obiecywać realizację polsko-ruskich planów organizacji Kościoła na Litwie ${ }^{342}$. Diecezja litewska mogła wejść tylko do gnieźnieńskiego związku metropolitalnego, ponieważ Ruś halicko-wołyńska swej metropolii nie posiadała, a status Kościoła ruskiego był wyjątkowy. Towtywił w razie opanowania tronu litewskiego miałby zapewne czym okupić się sprzymierzeńcom. Ruś Czarna i cała Jaćwież mogły być atutami w ręku auksztockiego kunigasa. W wypadku powodzenia tej linii politycznej usunięto by także wpływy krzyżackie na Litwie i ziemiach ościennych.

Krzyżacy po zawarciu pokoju ze Swiętopełkiem przystąpili natychmiast do przeciwdziałania. Spośród koncesji przyznanych książętom polskim w maju 1253 r. najbardziej niepokoiła Zakon ta, która oddawała księciu Kazimierzowi terytorium Galindów i inne ziemie, jakie ten książę sobie podporządkuje.

$\mathrm{Na}$ prośbę Zakonu legat papieski transumował dokument ugody z 19 października 1235 r. i sfałszowany przywilej serocki, rzekomo wystawiony przez księcia Kazimierza ${ }^{343}$. Wkrótce potem biskup warmiński Anzelm wystawił vidimus układu z 26 lipca 1252 r. ${ }^{344}$ Po tej akcji w kraju rozpoczęli Krzyżacy zabiegi w Kurii. Rezultatem ich była bulla papieska z 10 maja 1254 r., gwarantująca prawa Zakonu w podbitej już Barcji i sąsiadującej z nią Galindii ${ }^{345}$. Jeśli przyjmiemy, że już jesienią $1253 \mathrm{r}$. Siemowit i Bolesław Wstydliwy przestali popierać Kazimierza, to musimy przyznać, że wskutek tego polityka księcia kujawskiego poniosła w r. 1254 fiasko. Krzyżacy zresztą biernie nie czekali i w ciągu r. 1254 opanowali zbrojnie większą część Galindii. Zostali za to ekskomunikowani przez Opizona z Mezano ${ }^{846}$.

Natomiast na początku 1254 r. Bolesław Wstydliwy wszczął w Kurii starania o powołanie biskupstwa w Eukowie, leżącym , inter R u s cia m et Ducatum Cracovie". Starania te podjęte zapewne w porozumieniu z legatem Opizonem, gdyż na jego ręce przyszła zgoda papieska, wystawiona 13 lipca 1254 r. ${ }^{347}$ Wprawdzie o misyjnej roli biskupstwa nie ma w tej bulli ani słowa, to jednak domyślamy się, że taką rolę miało ono spełniać. Z późniejszej bulli papieskiej dowiadujemy się, że Łuków miał rzekomo leżeć „in confinio Letwanorum" ${ }^{348}$. Wystarczy rzut oka na mapę, by stwierdzić, że Łuków nie graniczył z Litwą, ale oddzielony był od niej

${ }^{342}$ Por. J. P owi erski, Polityka battyjska..., s. 330.

${ }^{348}$ PrUB I nr 276. Kazimierz zrzekł się $\mathrm{W}$ nim wiszelkich praw do ziem, które Zakon podbije.

${ }^{344}$ PrUB I nr 277. Por. J. K a r was iń ska, Sasiedztwo..., s. 39-40.

345 PrUB I nr 288.

${ }^{346}$ B. Wlodarski, Rywalizacja..., s. 44. O wypadkach tych mówi dopiero bulla papieska z 5 stycznia 1257 r. (PrUB I nr 331).

${ }_{347}$ Vetera Monumenta I nr 119.

348 Tamże, I nr 143. 
posiadłościami ruskimi, co zresztą stwierdzała bulla z r. 1254. Zatem myśl stworzenia z Łukowa bazy dla biskupstwa litewskiego mogła powstać tylko przy współpracy z książętami ruskimi. Nie sposób oprzeć się sugestii, że konsekracja Wita pozostawała w jakimś związku z próbami powołania biskupstwa łukowskiego i ze wspólną w tej sprawie inicjatywą małopolsko-mazowiecko-ruską. Wiemy też, że w tym czasie finalizowała się także sprawa obsady biskupstwa Mendoga przez kandydata zakonnego Chrystiana. Zabiegi polsko-ruskie miały przeciwdziałać posunięciom Krzyżaków. Ewentualne zwycięstwo nad Mendogiem mogło przechylić szalę na korzyść tych planów, a Kuria z pewnością z tym by się z czasem pogodziła.

Przedsięwzięcie to było przygotowywane wbrew Kazimierzowi. Dowodzi tego separatystyczny układ, zawarty jesienią $1254 \mathrm{r}$. w Raciążu między wicemistrzem krajowym Burchardem von Hornhausen a Danielem i Siemowitem. Zakon odstąpił im i ich dzieciom 1/3 ziemi jaćwięskiej, w zamian za pomoc przy jej podbiciu. Daniel i Siemowit mieli wspomagać Zakon nie tylko przeciw poganom, lecz przeciw każdemu, kto go zaatakuje ${ }^{\mathbf{3 4 9}}$. Odnosiło się to zapewne do Kazimierza ${ }^{\mathbf{3 5 0}}$, ale nie można także wykluczyć samego Mendoga. Układ ten jest dowodem, że polsko-ruskie plany były groźne dla Krzyżaków. Stąd próba polubownego rozwiązania konfliktu między Zakonem a Siemowitem i Danielem oraz prawie równoczesne ułożenie stosunków rusko-litewskich, usankcjonowane małżeństwem Szwarna Daniłowicza z córką Mendoga ${ }^{351}$. Ta ostatnia ugoda regulowała sprawę Rusi Czarnej i zawierała zapewne zgodę Litwy na zajęcie przez Daniela południowych ziem jaćwięskich ${ }^{352}$. Zapewne jeszcze w grudniu tego roku ruszyła na Jaćwież wyprawa ruska z posiłkami mazowieckimi i małopolskimi. Zakończyła się ona wielkim sukcesem Daniela. Prawdopodobnie wtedy przystąpiono do podziału ziem jaćwięskich w myśl traktatu raciąskiego (a może i chełmskiego) ${ }^{353}$. J. Nalepa przypusz-

${ }^{349}$ PrUB I nr 298. W oryginale brak daty dziennej. Wydawcy, Philippi i Wölky, domyślali się tutaj 24 listopada.

${ }_{350}$ J. Ka rwas ińska, jw., s. 41.

351 PSRL II 830-831. Wydarzenie to umieszczal u schyłku 1254 r. M. Hruszewski, Chronologia podij Hałyćko-Wolyńskoj litopysy, „Zapisy Naukowoho Towarystwa im. Szewczenka" 41 s. 38; tenże, Historia Ukrainy-Rusy, t. 3, Lwów 1905 , s. $74-76,81$.

${ }_{352}$ B. Włodarski, Polska $i$ Ruś..., s. 176.

353 PSRL II 831-835. Co do daty tej wyprawy istnieje spór w historiografii. Latopis hipacki umieszcza ją pod rokiem 1256. M. Hruszewski w swym studium nad chronologią latopisu hipackiego cofnął datę wyprawy do zimy 1254/5 (M. H r uszewski, jw., s. 38, 68). Podobnie przyjmował H. モow miański (Studia..., t. 2 s. 254) oraz H. P a s zkiewicz (Jagiellonowie..., s. 170, chociaż alternatywnie podał on zimę 1255/6). Później swój pogląd skorygował, przesuwając datę wyprawy na zimę 1255/6, jako że od schyłku 1254 r. aż do kwietnia 1255 r. Siemowit mazawiecki, którego latopis wymienia jako uczestnika wyprawy, siedział $\mathrm{w}$ więzieniu u brata $(\mathrm{H}$. Paszkiewicz, $\quad Z$ życia politycznego Mazowsza..., s. 215). Datę tę przyjmował też B. Włodarski (Polska $i$ Ruś..., s. 178). Wyprawa ta jednak jest bardziej 
cza, że wtedy do Mazowsza została włączona południowa część Połeksza, położona między dolną Wisą, Biebrzą i Nettą, szybko skolonizowana przez polski żywioł etniczny ${ }^{354}$. Natomiast Krzyżacy przystąpili do podboju sfederowanej z Jaćwieżą Nadrowii ${ }^{355}$.

Po wyprawie ruskiej Jaćwięgowie zobowiązali się do budowy ruskich grodów na swym terenie i do płacenia Rusi daniny. Tę ostatnią rzeczywiście w ciągu $1255 \mathrm{r}$. pobierał z ramienia Daniela niejaki Konstantyn ${ }^{356}$. Natomiast Bolesław Wstydliwy $\mathrm{z}$ wyprawy tej nie wyniósł żadnych korzyści, oprócz może części daniny jaćwięskiej, którą Konstantyn „wdast' Signiewu wojewodie posłusz'stwa radi uwies wsia ziemlia Liad'skaja jako dan' płatili sut' Jatwiazi że korolewi Daniłu, synowi wielikowo kniazia Romana" ${ }^{857}$.

Trudno tu nie zauważyć, że na początku r. 1255 lub pod koniec 1254 biskup litewski Wit zwrócił się do papieża z prośbą o przyjęcie rezygnacji ze swego stanowiska, prosząc jednak o zachowanie godności biskupiej (,non dignitati resignare sed lo c o"), na co papież 1 marca $1255 \mathrm{r}$. wyraził zgodę. Dokonało się to zapewne nie bez udziału Krzyżaków ${ }^{358}$. Zatem plany Bolesława Wstydliwego, podobnie jak wcześniejsze Kazimierza, doznały porażki. Przyczyniła się do tego ugoda litewsko-ruska zawarta przed podjęciem tej wyprawy lub wkrótce po niej.

Zniechęcenie do Daniela pchnęło Bolesława Wstydliwego do powrotu do wspólnej polityki z Kazimierzem. Ten ostatni, dowiedziawszy się o ugodzie krzyżacko-rusko-mazowieckiej, pod sam koniec r. 1254 (ale już po wyprawie na Jaćwież) uwięził Siemowita z małżonką (Perejasławą, córką Daniela) ${ }^{359}$. Kazimierz chciał zapewne doprowadzić przez to do zerwania brata z Zakonem, lecz ten wiedzial, że w roku następnym dojdzie do skutku wielka wyprawa krzyżacka na Sambię z udziałem króla

zrozumiała w kontekście wydarzeń 1254 r. Jesienią dochodzi do umowy raciąskiej z Krzyżakami. Równocześnie Daniel zawiera porozumienie z Litwą, zezwalające mu na podbój części Jaćwieży. Wyprawa mogła się odbyć zaraz w grudniu. Latopis podaje, że lód był tak śliski, iż walczący wpadali na siebie (PSRL II 833). Wyprawa mogła zaś zakończyć się w grudniu przed Bożym Narodzeniem $1254 \mathrm{r}$. Na wieść o rezultatach wyprawy i układzie raciąskim z Krzyżakami, Kazimierz pod sam koniec roku uwięził Siemowita. Sam zaś zawarł układ z Krzyżakami, godzący faktycznie w plany mlodszego brata.

${ }_{354}$ J. Nale pa, Połekszanie..., s. 25, 27. Przypuszcza on także, że Ruś włączyła do swego stanu posiadania ziemie jaćwięskie położone na lewym brzegu Niemna. Taki miał być początek przynależności leśnictwa perstuńskiego (czyli grodzieńskiego) i przełomskiego (Suwalszczyzna) do Grodna.

${ }_{355}$ J. P ow ierski, Rola..., s. 100.

355 PSRL II 835-836. Być może był on wojewodą chełmskim. Por. W. T. P aszuto, Oczerki..., s. 146.

${ }_{357}$ Tamże, 835 .

358 MPV III $\mathrm{nr} 73$.

${ }_{359} \mathrm{MPH}$ s.n. VI S. 35; VIII s. 102. J. Powierski (Stanowisko polityczne..., s. 30-31) przypuszcza, że być może wtedy Kazimierz storpedował planowaną przez Zakon wspólnie z Siemowitem wyprawę na Jaćwież, o czym dowiadujemy się z ugody Kazimierza z Zakonem z 1263 r. (PrUB I 2 nr 4). 
czeskiego Przemysła Ottokara II. Na pomyślnym przebiegu tej wyprawy bardzo zależało Krzyżakom. Dlatego w styczniu 1255 r. w Inowrocławiu zjawił się sam wielki mistrz Poppo von Osterna. W zawartym tam układzie zrzekł się Kazimierz wszelkich praw do Galindii i Połeksza, przyznanych mu przez Innocentego IV. W zamian za to Krzyżacy, prócz ponownej obietnicy przekazania mu $1 / 3$ ziemi lubawskiej, obiecali odstąpić także 1/3 tej ziemi, obiecanej w $1242 \mathrm{r}$. Bolesławowi mazowieckiemu. Przez układ ten Krzyżacy porzucali faktycznie sojusz z Siemowitem i Danielem ${ }^{360}$.

Układ inowrocławski został zatwierdzony przez Aleksandra IV 9 marca 1255 r. ${ }^{361}$ Do zawarcia go Kazimierz został zmuszony przez okoliczności polityczne. Dalszy bowiem przebieg wydarzeń wskazuje, że książę kujawsko-łęczycki bynajmniej z praw do podporządkowania sobie Galindii, i Jaćwieży nie zrezygnował.

Tymczasem pod rokiem 1255 Długosz, na podstawie nieznanego źródła, donosi nam o litewskiej napaści na Lublin ${ }^{862}$. Wokół tego faktu toczyła się w swoim czasie ożywiona dyskusja. J. Latkowski wątpił w ogóle, czy wyprawa ta miała miejsce i uważał, że „Litwini” wymienieni w bullach papieskich jako łupieżcy Polski to Żmudzini ${ }^{883}$. O. Halecki oraz H. Eowmiański przyjmowali, że wyprawa ta była dziełem Auksztocian, nie uznających władzy Mendoga, gdyż Aleksander IV w swej bulli z 7 sierpnia 1255 r. wyraźnie stwierdził, że napaść była dokonana przez Litwinów, Jaćwięgów i innych pogan, „qui Romanam ecclesiam nunquam matrem sua professione fidei agnoverunt". Wobec faktu, że Mendog był chrześcijaninem, bulla wyraźnie miała wskazywać, że chodzi tu o pogańskich Litwinów ${ }^{364}$. H. Paszkiewicz przeciwstawiał się tej koncepcji, twierdząc, że chrzest Mendoga był aktem czysto politycznym, obliczonym na doraźne korzyści, wobec czego wyprawę taką mógł podjąć i sam Mendog ${ }^{865}$.

Sam fakt wyprawy chrześcijańskiej Litwy na chrześcijańską Polskę nie byłby może wcale dziwny wobec tego, co wiemy o wojnach między chrześcijanami. Zastanawiać muszą natomiast papieskie wezwania do krucjat przeciw Litwinom. Już H. Łowmiański podkreślił, że papież nie mógł przecież wysyłać krucjat przeciw Mendogowi, a jednocześnie brać go

360 PrUB nr 303. Dokumenty nie mają daty dziennej, tylko roczną - $1255 \mathrm{r}$. B. Włodarski (Rywalizacja..., s. 45, p. 164) przesuwał układ do grudnia 1254 r. Natomiast J. Ka r wa s ińska (jw., s. 43, p. 1) uważała, że miał on miejsce na początku stycznia $1255 \mathrm{r}$. Ten drugi pogląd jest bardziej prawdopodobny.

361 PrUB I nr 313.

${ }^{362}$ Długosz, VII s. 125; A. S e mk ow ic z, Krytyczny rozbiór Dziejów Polskich sana Dtugosza, Kraków 1887, s. 274.

${ }^{363}$ J. L a tk ow ski, Mendog..., s. 402. s. 339

364 O. Halecki, Dzieje unii..., s. 19; H. Eowmiański, Studia..., t. 2 ${ }^{865} \mathrm{H}$. P a s zkiewicz, Jagiellonowie..., s. 97. 
w swą opiekę i pozwalać na koronację następcy ${ }^{868}$. Dlatego historyk ten przyjmował, że w tym czasie toczyła się na Litwie walka wewnętrzna, w trakcie której Mendog podporządkował sobie pozostałe związki terytorialne, nie uznające dotąd jego władzy ${ }^{\mathbf{3 6 7}}$. Przeczył temu H. Paszkiewicz, uważając, że tak rozległa geografia napaści litewskich w tym okresie byłaby niezrozumiała wobec braku istnienia scentralizowanej władzy monarszej ${ }^{\mathbf{s 6 8}}$.

To, co wiemy obecnie o charakterze wczesnej monarchii litewskiej, pozwala nam te różne poglądy ze sobą pogodzić i związać. Państwo na tym etapie rozwoju, nie mogące jeszcze zaspokoić ambicji swych nobilów drogą eksploatacji własnych poddanych, musiało godzić się na łupieżcze najazdy, stanowiące główne źródło bogacenia się. Co najwyżej, można było wywierać pewien wpływ na geografię tych wypraw ${ }^{\mathbf{3 6 9}}$. Nie słyszymy bowiem nic o napadach na Inflanty, wobec tego że Mendog utrzymywał dobre stosunki z Zakonem. Natomiast liczne są w tym czasie wyprawy na Ruś ${ }^{370}$. Wyprawy te młoda organizacja państwowa mogła okresowo powstrzymać, ale nie mogła ich całkiem zahamować bez narażenia się na konflikty wewnętrzne. Wyprawy łupieżcze podejmowały zatem i związki terytorialne uznające władzę Mendoga ${ }^{371}$. Sam król musiał się z ich wolą liczyć. Swietnie widać to na przykładzie złupienia okolic Łucka w r. 1255 przez Litwinów Mendoga, po niefortunnej wyprawie na Zwiahel. Litwini złupili teren księstwa Daniela i Wasylka, mimo układu z r. 1254, i dokonali tego Litwini podlegli Romanowi Daniłowiczowi, lennikowi Mendoga, a brali w tym udział także Rusini z Rusi Czarnej ${ }^{872}$. Papiestwo nawołujące do krucjat przeciw Litwinom miało zapewne na uwadze samowolne bandy łupieskie, bardzo uciążliwe dla sąsiednich państw chrześcijańskich. Do band tych przyłączali się Jaćwięgowe i Prusowie, również chciwi zysków, jakie przynosiły wyprawy. W tym kontekście litewski najazd na Lublin wcale nie dziwi. Można się tylko zastanawiać, czy był to napad o charakterze rabunkowym czy odwetowym. To, co wiemy o polityce Bolesława Wstydliwego z ubiegłego, 1254 r., zmusza nas przynajmniej do rozważenia tej sprawy, aczkolwiek wobec ubóstwa materiału źródłowego rozstrzygnięcie tej kwestii jest rzeczą nader skomplikowaną.

Przypuszcza się, że w związku z czeską wyprawą na Sambię w r. 1255 doszło do pewnego zbliżenia między Przemysłem Ottokarem

${ }^{866}$ H. Łow miański, Studia..., t. 2 s. 335.

${ }^{867}$ Tamże, s. 343-346.

$368 \mathrm{H}$. Paszkiew ic z, jw., s. 58-61.

869 H. Łow mi ański, Studia..., t. 2 s. 201, 224-225.

98.

370 Regesta Lithuaniae $\mathrm{nr} 274,351,356,357$; H. Pasziewicz, jw., s. 95,

871 H. Łow miański, Studia..., t. 2 s. 339.

372 PSRL II $839-840$. 
II a książętami polskimi. Król czeski, pragnąc zneutralizować książąt polskich $\mathrm{w}$ przyszłym konflikcie $\mathrm{z}$ Węgrami, poparł polskie plany chrystianizacyjne wobec ludów bałtyjskich. Dużo inicjatywy w tym względzie wykazał znowu Kazimierz kujawsko-łęczycki, usiłujący zbliżyć się nawet do orientacji czeskiej ${ }^{373}$. W kwietniu $1255 \mathrm{r}$. wypuścił on z więzienia Siemowita i jego małżonkę i pogodził się z bratem. W maju 1255 r. w Krakowie odbył się zjazd książąt polskich, który, aczkolwiek poświęcony głównie sprawom pomorsko-wielkopolskim, mógł także zająć się ogólnopolską polityką północną ${ }^{374}$.

6 sierpnia 1255 r. Aleksander IV, zwracając się do biskupów Polski, Czech, Moraw i Austrii (krajów Przemysła Ottokara), nakazał franciszkaninowi Bartłomiejowi $\mathrm{z}$ Czech głosić $\mathrm{w}$ tych krajach krucjatę przeciw Litwinom i Jaćwięgom, co na pewno było wynikiem polskich starań ${ }^{875}$. Co jest ciekawe, nie słyszymy odtąd o Rusinach, nie zainteresowanych już tymi sprawami, a być może wrogo do nich usposobionych.

W 1256 r., zapewne nie bez związku z akcją Krzyżaków przeciw Jaćwieży, powstają ponowne kontrprzedsięwzięcia polskie ${ }^{376}$. W pierwszych miesiącach r. 1256 Kazimierz zawiadomił Kurię, że pewni poganie, zwani Jaćwięgami, chcą się dobrowolnie ochrzcić i przejść pod opiekę księcia. Aleksander IV nawiązawszy do koncesji Innocentego IV, przyznanych Kazimierzowi i Bolesławowi w r. 1253, polecił 15 lipca 1256 r. biskupowi wrocławskiemu, przeorowi dominikanów chełmińskich oraz Bartłomiejowi z Pragi, aby pogan tych traktowali jako chrześcijan, a wszystkich występujących przeciw temu obłożyli klątwą ${ }^{377}$. Ze źródeł pochodzących z roku następnego dowiadujemy się, że klątwą tą zostali obłożeni Krzyżacy ${ }^{378}$. Natomiast Bolesław Wstydliwy, siostra jego Salomea oraz mistrz templariuszy dla Niemiec i Slawonii zwrócili się u schyłku r. 1256 do Kurii z prośbą o założenie biskupstwa w Łukowie i wyniesienie na nie Bartłomieja z Czech ${ }^{379}$. Pod koniec tego roku rozpoczęto też przygotowania

373 J. P owierski, Sprawa Prus i Jaćwieży..., s. 257.

374 B. Włodarski, Rywalizacja..., s. 46; R. Wróblewski, Problem jaćwieski..., s. 11 .

375 Vetera Monumenta I $\mathrm{nr} 126$.

${ }^{376}$ B. Wło darski, Rywalizacja..., s. 48-49. Na to, że Krzyżacy podjęli jakąś wyprawę zbrojną wskazuje prośba Kazimierza o podtrzymanie klątwy na Zakon za wyprawy przeciwko tym, którzy dobrowolnie chcą się ochrzcić i poddać Kazimierzowi (Vetera Monumenta I nr 141). W r. 1255 Krzyżacy rozwijali akcję przeciwko sąsiadującej z Jaćwiężą Nadrowii (Dusburg, s. 93).

377 Vetera Monumenta I nr 139; PrUB I nr 329.

878 Por. wyżej przypis 376.

379 Vetera Monumenta I nr 143. Bartłomiej z Czech był postacią związaną ze środowiskiem krakowskim. 17 kwietnia i 18 maja 1255 r. pośredniczył w sporze między kapitułą krakowską a księciem (KDKK I nr 42, 43). Wł. A braham (jw., s. 159) domyślał się, że Bartłomiej w interesie planów Bolesława Wstydliwego usiłował przychylnie nastawić kapitułę krakowską w kwestii wykrojenia biskupstwa łukowskiego z diecezji krakowskiej. 6 i 7 sierpnia 1255 r. otrzymał on zadanie gło- 
do organizacji krucjaty przeciw Litwinom, Jaćwięgom, innym poganom i s chi z matykom. Dowiadujemy się o tym z bulli Aleksandra IV z 5 stycznia 1257 r. ${ }^{380} \mathrm{~W}$ tym dniu wziął papież w opiekę księcia Kazimierza i innych książąt mających uczestniczyć w krucjacie. Z bulli tej dowiadujemy się także, że krucjata miała być skierowana także przeciw schizmatykom, czyli Rusinom. Ci ostatni, mając sojusz z Mendogiem, nie kwapili się zapewne do tolerowania polskich planów podboju Jaćwieży, co do której Ruś od dawna miała własne zamiary. Być może, doszło nawet do jakichś wrogich incydentów. W każdym razie około r. 1256 Daniel zerwał ostatecznie unię ze Stolicą Apostolską ${ }^{381}$. Dla króla ruskiego unia ta straciła wszystkie walory polityczne. Część Jaćwieży została opanowana przez Ruś, pozostała płaciła jej trybut. Nabytki ruskie zostały przez Zakon zaakceptowane. Zaakceptowała je także Litwa. Co więcej, osadziła na Rusi Czarnej w charakterze swego lennika syna Daniela Romana. Niebezpieczeństwo tatarskie w tym czasie Rusi nie groziło, a nawet gdyby groziło ${ }^{382}$, Daniel przekonał się, że na pomoc Zachodu trudno jest liczyć. Natomiast własne społeczeństwo nie było do unii przekonane ${ }^{383}$. Dlatego Daniel unię porzucił. Dowiadujemy się o tym z pism Aleksandra IV z 13 lutego 1257 r. ${ }^{384} \mathrm{~W}$ jednym z nich, skierowanych do biskupów wrocławskiego i ołomunieckiego, nakazał im papież wezwać Daniela do powrotu do Kościoła rzymskiego, a w razie niesubordynacji obłożyć go karami kościelnymi, wraz z możliwością użycia ,[auxilium] brachii secularis" ${ }^{385}$. Wł. Abraham przypuszczał, że do porzucenia unii przez Daniela przyczyniła się sama Stolica Apostolska, nie szczędząca przywilejów pierwszemu królowi Litwy, sprzecznych z interesem Rusi ${ }^{386}$.

Tymczasem 1 lutego 1257 r. Aleksander IV polecił arcybiskupowi gnieźnieńskiemu i biskupowi krakowskiemu utworzyć biskupstwo w Łukowie i wynieść na nie franciszkanina Bartłomieja z Pragi ${ }^{887}$. W ten sposób miały być zrealizowane plany sprzed trzech lat. Wspólne zabiegi o ich realizację ze strony Kazimierza i Bolesława Wstydliwego są dowodem na to, że książęta ci znów zbliżyli się do siebie. Przypuszcza się, że głównie zależało na tym Kazimierzowi. W odnowieniu dobrych stosunków z Bolesławem Wstydliwym widział on zabezpieczenie przed księciem wielkopolskim, który przez małżeństwo zacieśnił swe więzy z obozem

szenia krucjaty przeciw Litwinom i Jaćwięgom (MPV III nr 75, 76, 77). Pod koniec tego roku udał się osobiście do Kuriii (Wł. A bra ham, jw., s. 160).

380 MPV III nr 84; Vetera Monumenta I nr 142.

381 Wł. A braham, jw., s. $135,140$.

382 W. T. Paszuto, Oczerki..., s. 282, 283. Latopis hipacki twierdzi, że Daniel „dierżasze rat' s Kurem'soju i nikoły że nie bojasia Kurem'sje” (PSRL II 846).

${ }^{383}$ Wł. A brah a m, jw., s. $129,137-141$.

384 DPRHUI I $\mathrm{nr} 34,35$.

385 Tamże, nr 35.

386 Wł. A braram, jw., s. 136.

387 Vetera Monumenta I nr 144.

6 - Analecta Cracoviensia 
prowęgierskim ${ }^{388}$. Obecne plany, wobec zadań misyjnych biskupstwa łukowskiego, były szersze od tych z roku 1254. Otóż biskupstwo to miało objąć swą jurysdykcją nie tylko Litwinów, lecz także Jaćwięgów ${ }^{389}$. Istniała jednak nadal istotna ku temu przeszkoda, a mianowicie biskup jaćwięski przebywał poza swą diecezją i nie był skłonny do niej wracać, a raczej nie miał ku temu specjalnych możliwości ${ }^{390}$. Należało o tym powiadomić odpowiednie władze kościelne i, jeśli nie zaraz, to w przyszłości istniała możliwość włączenia do diecezji łukowskiej terenów jaćwięskich. Tego rodzaju zabiegi $\mathrm{w}$ istocie zostały podjęte na szczeblu władz zakonu dominikańskiego, członkiem którego był biskup Henryk. W formularzu Marina de Eubulo zachował się odpis bulli papieskiej (nie datowany), w której papież nakazywał biskupowi praskiemu skłonić biskupa Henryka pod groźbą ekskomuniki, by powrócił na misję jaćwięską. Biskup ten bowiem ,per Alamaniam, Bohemiam, Poloniam et Moraviam tanquam vagus presumebat discurrere", a o biskupstwo swe się nie troszczył. Henryk usprawiedliwiał się potem przed papieżem, że na teren misji wrócić nie może bez narażenia życia, z powodu częstych napadów pogan i Tatarów ${ }^{391}$. Możemy tylko przypuszczać, że jego powrót był nie na rękę tak stronie polskiej jak i krzyżackiej. Strona polska zainteresowana była zapewne tym razem bardziej misją w kraju Jaćwięgów niż na Litwie. Zresztą samą Jaćwież uważano nieraz w tym czasie już za Litwę ${ }^{302}$. Być może Henryka, podobnie jak uprzednio Wita zmuszono do rezygnacji z kierownictwa misją jaćwięską, pozostawiając mu tylko tytuł biskupa Jaćwięgów.

Ambitne plany misyjne książąt polskich zostały wkrótce przekreślone przez dyplomację krzyżacką. Jeszcze w kwietniu 1257 r. Aleksander IV rozszerzył kompetencje biskupa Bartłomieja ${ }^{393}$, ale kilka misięcy później wszystkie koncesje wycofał. Zakon bowiem już w maju 1257 r. zapowie-

388 B. Włodarski, Rywalizacja..., s. 49. Bolesław wielkopolski zbliżył się do dworu krakowskiego przez małżeństwo z Jolantą, siostrą Kingi.

${ }^{389} \mathrm{~W}$ formularzu Mariana de Ebulo znajduje się nie datowana bulla Aleksandra IV nakazująca arcybiskupowi gnieźnieńskiemu wyświęcenie odpowiedniej osoby na biskupa Jaćwięgów (MPV III nr 512).

390 W 1255 r. brał on udział w krucjacie Przemysła Ottokara do Sambii (K. Górski, Descriptiones..., s. 8), w 1258 r. spotykamy go w Wiedniu, potem w Saarburgu i w Pradze: Regesta Lithuaniae nr 355 (Vienne 12 V 1258 r.), nr 361 (Saarburg 30 VII 1255 r.), nr 387 (Pragae 24 XII 1261 r.), nr 395 (Helmgersperge 30 VII 1261 r.).

891 MPV III $\mathrm{nr} 513$.

392 „Henricus episcopus Witsaciensis in Litovia” (Regesta Lithuaniae $\mathrm{nr}$ 355).

393 PrUB I 2 nr 7. W związku z nową akcją misyjną pozostaje zapewne zjazd Kazimierza, Siemowita i Bolesława Wstydliwego w Korczynie w marcu $1257 \mathrm{r}$. (KDM I nr 44; II $\mathrm{nr} 452$; Rocznik mansjonarzy krakowskich MPH III s. 73) B. Włodarski (Rywalizacja..., s. 50) przypuszczał, że na zjeździe tym starał się książę krakowski przeciągnąć do obozu prowęgierskiego księcia Kazimierza. Nie wykluczone, że już wtedy zaznaczyły się między książętami rozdźwięki, które w maju doprowadziły do rozkładu koalicji i pchnęly Kazimierza do obozu proczeskiego. 
dział wniesienie apelacji, oskarżając księcia Kazimierza o pretensje do ziem, z których zrezygnował, a do których Zakon ma wyłączne prawa ${ }^{394}$. Rozgrywki te zakończyły się sukcesem Krzyżaków. W sierpniu $1257 \mathrm{r}$. papież odwołał polsko-czeską krucjatę, głoszoną przez franciszkanów, i nakazał poprzeć prokrzyżacką krucjatę do Prus. Aleksander IV zniósł także ekskomunikę ciążącą na Krzyżakach i udzielił Zakonowi nowych przywilejów ${ }^{395}$.

Prawie równocześnie Kazimierz, zagrożony wojną z Bolesławem Pobożnym, który w czerwcu 1257 r. zjednoczył Wielkopolskę ${ }^{398}$, zawarł wraz z Siemowitem ugodę z Krzyżakami we Włocławku (4 sierpnia 1257). $\mathrm{Na}$ mocy tej ugody, książęta zrzekli się pretensji do ziem posiadanych przez Zakon lub w przyszłości przez niego nabytych zbrojnie lub pokojowo. Krzyżacy ze swej strony ponownie przyrzekli Kazimierzowi przekazanie należnej mu części ziemi lubawskiej. Ten ostatni wyrzekł się także wszystkich pretensji do ziemi Sasinów. Zakon zgodził się na wykup ze swych rąk wsi Rogowo, leżącej tuż pod Inowrocławiem. Siemowit natomiast zrzekł się pretensji do ziem przez Zakon posiadanych, a także pretensji do odszkodowania za naruszanie granic swego księstwa przez rycerzy zakonnych ${ }^{397}$. Ugoda włocławska przemilczała sprawę Jaćwieży. Krzyżacy uważali sprawę za zamkniętą, chociaż dokładnie nie określoną. Aby okazać swą dobrą wolę, Zakon przekazał wreszcie Kazimierzowi należną mu część ziemi lubawskiej ${ }^{398}$. Książę ten nie miał jednak zamiaru rezygnować z planów ekspansji na ziemie pruskie. Ugoda włocławska była dla niego tymczasowym posunięciem taktycznym. Istnieją bowiem poszlaki, że już jesienią $1257 \mathrm{r}$. znowu planował on jakąś akcję na froncie północnym ${ }^{899}$. Zimą $1257 / 58$ w porozumieniu $\mathrm{z}$ biskupem sambijskim, skłóconym z Krzyżakami, spalił posiadłości Zakonu w Nieszawie oraz storpedował wyprawę krzyżacką na Jaćwież ${ }^{400}$.

Niestety Kazimierz znowu był osamotniony w swej polityce. Wkrótce uformowała się nawet wroga mu koalicja książąt, do której weszli Bolesław Pobożny, Bolesław Wstydliwy, Warcisław dymiński, Daniel halicki, a nawet brat jego Siemowit ${ }^{401}$. J. Powierski przypuszcza, że najazd litewski Trojnata na Mazowsze w r. 1258 mógł być inspirowany przez Krzyżaków, który w ten sposób chcieli księcia mazowieckiego zbliżyć do

394 PrUB I 2 nr 10.

395 PrUB I 2 nr 21.

396 B. Włodarski, Rywalizacja..., s. 52; J. Powierski, Sprawa Prus i Jaćwieży..., s. 258.

${ }_{937}$ PrUB I 2 nr $19,20$.

398 J. K a rwas ińska, Sasiedztwo..., s. 50-51.

399 J. P ow ierski, Sprawa Prus $i$ Jaćwieży..., s. 261-262.

400 Tamże; CDWarm I nr 38.

401 B. Włodarski, Rywalizacja..., s. 52-53. 
siebie, a odepchnąc od związków z bratem ${ }^{402}$. W ciągu r. 1258 do obozu wrogów księcia kujawskiego weszli biskupi kujawski i płocki, poróżnieni z Kazimierzem na tle sprawy testamentu Boguszy ${ }^{403}$. Natomiast Kazimierz zapewnił sobie poparcie Świętopełka oraz biskupów pruskich, zwłaszcza chełmińskiego, któremu nadał oddaną mu przez Krzyżaków część ziemi lubawskiej ${ }^{404}$. Walki między książętami uniemożliwiły prowadzenie konsekwentnej polityki bałtyjskiej. Siemowit mazowiecki, skutecznie skłócony ze starszym bratem, a także w obliczu niebezpieczeństwa tatarskiego zbliżył się do Zakonu, zawierając z nim 15 czerwca 1260 r. układ w Troszynie. Porozumienie troszyńskie potwierdzało stan posiadania Siemowita i Zakonu w ziemi jaćwięskiej. Landmistrz krzyżacki Hartmund Grumbach potwierdził Siemowitowi nadanie $1 / 6$ tej ziemi, darowanej mu niegdyś przez wicelandmistrza Burcharda. W zamian książę mazowiecki zobowiązał się, że dopóki Jaćwięgowie nie zostaną pobici, będzie wyprawiał się przeciw nim wspólnie z Zakonem. Tylko niebezpieczeństwo najazdu jego własnej dzielnicy mogło zwolnić go od tego udziału. Porozumienie przewidywało także obowiązek rady ze strony Zakonu w wypadku, gdyby w czasie podboju Jaćwieży dzielnica Siemowita została poszkodowana przez wrogów chrześcijaństwa. Po podboju Jaćwięgów Siemowit zobowiązał się zwalczać wspólnie z Krzyżakami wszystkich najeźdźców, a także dostarczyć posiłków Zakonowi w wypadku powstania neofitów ${ }^{405}$.

Porozumienie troszyńskie było zatem poświęcone głównie kwestii jaćwięskiej, która, jak wiemy, stanowiła kość niezgody między książętami polskimi a Zakonem. Status Jaćwięgów w przeciągu tego okresu nie jest jasno określony. Wydaje się, że część z nich uznawała władzę Mendoga, część zwierzchnictwo Rusi, część zaś ich była zupełnie niezależna. Możliwe, że ani Ruś, ani Litwa nie zdołały narzucić Jaćwieży swego zwierzchnictwa w sposób zupełny. Możliwe, że udało się tego dokonać Litwie krótko przed najazdem tatarskim, co oczywiście spowodowało zerwanie dobrych stosunków z Rusią. Tłumaczyłoby to czynny udział Rusinów w akcji tatarskiej przeciw Litwie, a także to, że najazd tatarski objął prócz Litwy także i Jaćwież. Ale po tym najeździe związek Jaćwieży z Mendogiem uległ osłabieniu, gdyż Mendog, szukając oparcia w Zakonie, darował mu w r. 1259 całą ziemię jaćwięską, prócz kilku włości, które faktycznie posiadał.

Stąd porozumienie troszyńskie kierowało się zepewne głównie przeciw Rusi, głównej pretendentce do ziemi jaćwięskiej. Charakterystyczne, że

${ }^{402}$ J. P ow ie rski, Ksiqżęta polscy..., s. $367-368$.

${ }^{403}$ J. P owierski, Sprawa Prus i Jaćwieży..., s. 266.

404 B. Włodarski, Rywalizacja..., s. 52; UC nr 51; por. J. Powierski, Sprawa Prus $i$ Jaćwieży..., s. 260. Przekonująco wyjaśnił on problem tej darowizny, która natychmiast skłóciła z Zakonem biskupa i kapitułę chełmińską (PrUB I 2 nr 50).

405 PrUB I $2 \mathrm{nr}$ 104; J. P owierski, Ksiqżęta polscy..., s. 381. 
układ ten nic nie wspominał o 1/6 ziemi Jaćwięgów darowanej niegdyś Danielowi. Przypuszczalnie Siemowit liczył się z gniewem Daniela i możliwością kontrakcji na terenie swego księstwa.

Zbliżenie Siemowita do Zakonu przyniosło mu w ostateczności zgubę. Po wybuchu powstania pruskiego i po apostazji Mendoga sytuacja polityczna uległa bowiem gwałtownej zmianie. Próby posiłkowania Krzyżaków w akcji przeciw Litwie sprowadziły litewski najazd na Mazowsze, w czasie którego zginął książę mazowiecki (czerwiec 1262 r.) ${ }^{406}$.

Od śmierci Siemowita nie wysuwa już żadnych planów jaćwięskich także Kazimierz, który w czasie powstania pruskiego zawarł nawet sojusz z pogańską Litwą. Natomiast niepokoje w tym kraju po śmierci Mendoga i Trojnata starał się wykorzystć Bolesław Wstydliwy. 31 grudnia 1263 r. uzyskał on bullę papieską, nakazującą biskupowi krakowskiemu wysłanie zdolnych misjonarzy na Litwę i podjęcia tam odpowiednich kroków wokół zorganizowania Kościoła ${ }^{407}$. W połowie czerwca $1264 \mathrm{r}$. zorganizował książę krakowski wyprawę na Jaćwież, która zakończyła się dużym sukcesem ${ }^{408}$. Zmusiła ona Jaćwięgów do szukania pomocy u nowego władcy Litwy Trojnaty ${ }^{409}$. W odwecie za najazd na Jaćwięgów dosięgła Małopolskę wyprawa litewsko-ruska ${ }^{410}$. Natomiast polskie starania o organizację kościelną na Litwie zaniepokoiły Krzyżaków. Po śmierci Chrystiana postarali się o mianowanie biskupem litewskim jakiegoś Jana, który się nigdy na Litwie nie pokazał.

Polskie próby chrystianizacji Litwy i Jaćwieży w połowie XIII w. zakończyły się niepowodzeniem. W dużej mierze było to winą książąt polskich, którzy nie zdołali stworzyć jednolitego frontu wobec spraw bałtyjskich. Sprawy te uważali oni za drugorzędne. Jedynie Kazimierz kujawsko-łęczycki dążył konsekwentnie do podporządkowania sobie ziem pruskich i jaćwięskich. Niestety brak sprzyjających okoliczności politycznych i osamotnienie na tym gruncie nie pozwoliły mu tych planów zrealizować. Inni książęta polscy, którzy interesowali się zagadnieniami bałtyjskimi, Siemowit i Bolesław, również nie działali na tym polu konsekwentnie. Siemowita mazowieckiego nie było stać na wypracowanie swej

${ }^{406}$ Zestawienie źródeł w: Regesta Lithuaniae nr 393. Poprawki błędnej informacji kroniki wielkopolskiej (MPH s.n. VIII s. 115) dokonuje J. P o w i er sk i (Stanowisko polityczne s. 15-19). Por. tegoż, Wybuch II powstania pruskiego..., s. 313.

407 Vetera Monumenta I nr 148.

${ }^{408}$ MPH s.n. V s. 91; II s. 839, 878; III s. 171.

409 B. Wlodarski, Problem jaćwiński..., s. 33.

410 PSRL II 864. 
własnej polityki. Ekspansję w kierunku Jaćwieży prowadził on wspólnie z książętami ruskimi, wyraźnie przez nich zdominowany. Współpraca z Rusią w dziedzinie polityki jaćwięskiej miała już swą tradycję. Wyprawy wspólne z Rusinami podejmował Konrad mazowiecki, lecz w przeciwieństwie do ojca Siemowitowi nie udało się utrzymać równowagi wpływów i w konsekwencji ulegał zręczniejszym Romanowiczom. Ku tym ostatnim pchała go również chęć uniezależnienia się od starszego brata, usiłującego podporządkować go sobie przynajmniej w zakresie wspólnej polityki zewnętrznej. Niechęć Siemowita do Kazimierza pchnęła go w końcu do obozu wrogów tego ostatniego. Zbliżyła go zwłaszcza do Krzyżaków, których posiłkował nawet $\mathrm{w}$ czasie II powstania pruskiego. Polityka ta sprowadziła najazd litewski na Mazowsze, w czasie którego śmierć poniósł sam książę. Bolesława Wstydliwego w krąg spraw bałtyjskich włączył sojusz z Romanowiczami i wspólne z książętami ruskimi współdziałanie po stronie węgierskiej w walce o dziedzictwo austriackie. Oddziaływał także na niego w tym kierunku Kazimierz, ale w efekcie przeważyły sympatie polityczne, łączące się z orientacją węgierską, z którą związany był także wróg Kazimierza - książę wielkopolski. Sprzeczności interesów między książętami ułatwiały działanie dyplomacji krzyżackiej, której dość łatwo udawało się paraliżować polskie plany chrystianizacyjne ludów bałtyjskich. Niesnaski wśród książąt polskich potrafili wykorzystać także zręczni Romanowicze.

Litwa w tym okresie czasu, mimo iż proces państwowotwórczy miała już za sobą, nie osiągnęła jeszcze etapu państwa feudalnego, zdolnego zapewnić podstawy funkcjonowania organizacji kościelnej, przystosowanej właśnie do struktur feudalnych. W tej sytuacji monarchia litewska nie była $\mathrm{W}$ stanie skutecznie popierać misji chrześcijańskiej. Z chwilą, kiedy władca litewski nie mógł liczyć na poparcie własnego społeczeństwa, musiał ulegać wpływom obcym, a te w końcu okazały się zbyt uciążliwe. $\mathrm{Z}$ drugiej strony, mając do wyboru między perspektywą stworzenia ogólnobałtyjskiej monarchii pod swym zwierzchnictwem a chrystianizacją własnego społeczeństwa, co nie obyłaby się zapewne bez przemocy, Litwa wybrała pierwszą możliwość. Przyszłość miała pokazać, że nie była to decyzja najszczęśliwsza. Ogólnobałtyjskiej monarchii nie udało się stworzyć, natomiast pogańska Litwa została narażona na agresję niemiecką, której rezultatów nie można było przewidzieć. 


\section{WYKAZ SKRÓTÓW \\ WYDAWNICTW ŹRÓDŁOWYCH I CZASOPISM CYTOWANYCH W PRZYPISACH}

$\mathrm{CDH}$

CDArp

CDMG

CDWarm

CL

Długosz

DPRHUI

Dusburg

Grünhagen

HUB

KDKK

KDM

KDW

$\mathrm{KH}$

$\mathrm{KMW}$

LR

LUB

MGH SS

$\mathrm{MPH}$

MPH s.n.

MPV

NPL
- Codex diplomaticus Hungariae, ed. G. Fé je r, t. 4, Budae 1829.

- Codex diplomaticus Arpadianus continuatus, ed. G. W e nz e 1, t. 7, Pest 1869.

- Codex diplomaticus et commemorationum Masoviae generalis, ed. J. K. Kochanow ski, Warszawa 1919.

- Codex diplomaticus Warmiensis, ed. K. P. Woelky, J. M. $\mathrm{S}$ a a g e, Mainz 1860.

- Heinrici de Lettis Chronicon Lyvoniae, ed. W. A r ndt, [w:] MGH SS t. 23, Hannoverae 1874, s. $231 \mathrm{n}$.

- Jana Długosza Roczniki czyli Kroniki stawnego Królestwa Polskiego, t. 4 (ks. VII-VIII), Warszawa 1974.

- Documenta pontificum Romanorum historiam Ucrainae illustrantia, ed. A. Weły ky j, t. 1, Romae 1953.

- Chronicon terrae Prussiae von Peter von Dusburg, ed. M. Toeppen, [w:] SRP t. 1, Leipzig 1861-1874, s. 21-269.

- Regesten zur schlesischen Geschichte, ed. C. Gr ün hagen, Bd. 2: Codex diplomaticus Silesiae, t. 7, Breslau 1875.

- Hansisches Urkendenbuch, ed. K. Höhlbaum, t. 1, Halle 1879 .

- Kodeks dyplomatyczny katedry krakowskiej, ed. F. Piekos iński, t. 1, Kraków 1874.

- Kodeks dyplomatyczny małopolski, ed. F. Piekosiński, t. 1-2, Kraków 1876-1886.

- Kodeks dyplomatyczny wielkopolski, ed. I. Zakrzewski, t. 1, Poznań 1877.

— „Kwartalnik Historyczny”

- „Komunikaty Mazursko-Warmińskie”

- Livländische Reimchronik, ed. L. M a y er, Paderborn 1876.

- Liv-, Est- und Curländische Urkundenbuch, ed. F. G. von Bunge, t. 1, Reval 1853.

- Monumenta Germaniae Historica. Scriptores, t. $23=\mathrm{CL}$ oraz s. 523-561; t. 25: Liber de calamitate ecclesiae Moguntinae, ed. H. R e i m e r, Hannoverae 1880, s. 236-248.

- Monumenta Poloniae Historica, ed. A. Bielowski, t. 2-3, Lwóiw 1872-1878.

- Monumenta Poloniae Historica, series mova, t. 5: Najdawniejsze roczniki krakowskie $i$ kalendarz, ed. $\mathrm{Z}$. Kozłow ska- B u dk owa, Warszawa 1978; t. 6: Roczniki wielkopolskie, ed. B. K ür b is, Warszawa 1962; t. 8: Kronika wielkopolska, ed. B. K ì r b i s, Warszawa 1970.

- Monumenta Poloniae Vaticana, ed. J. Ptaśnik, t. 3, Cracoviae 1914.

- Nowogrodskaja perwaja letopis starszego $i$ mtadszego izwodow, ed. A. N. Nazonow, Moskwa-Leningrad 1950. 


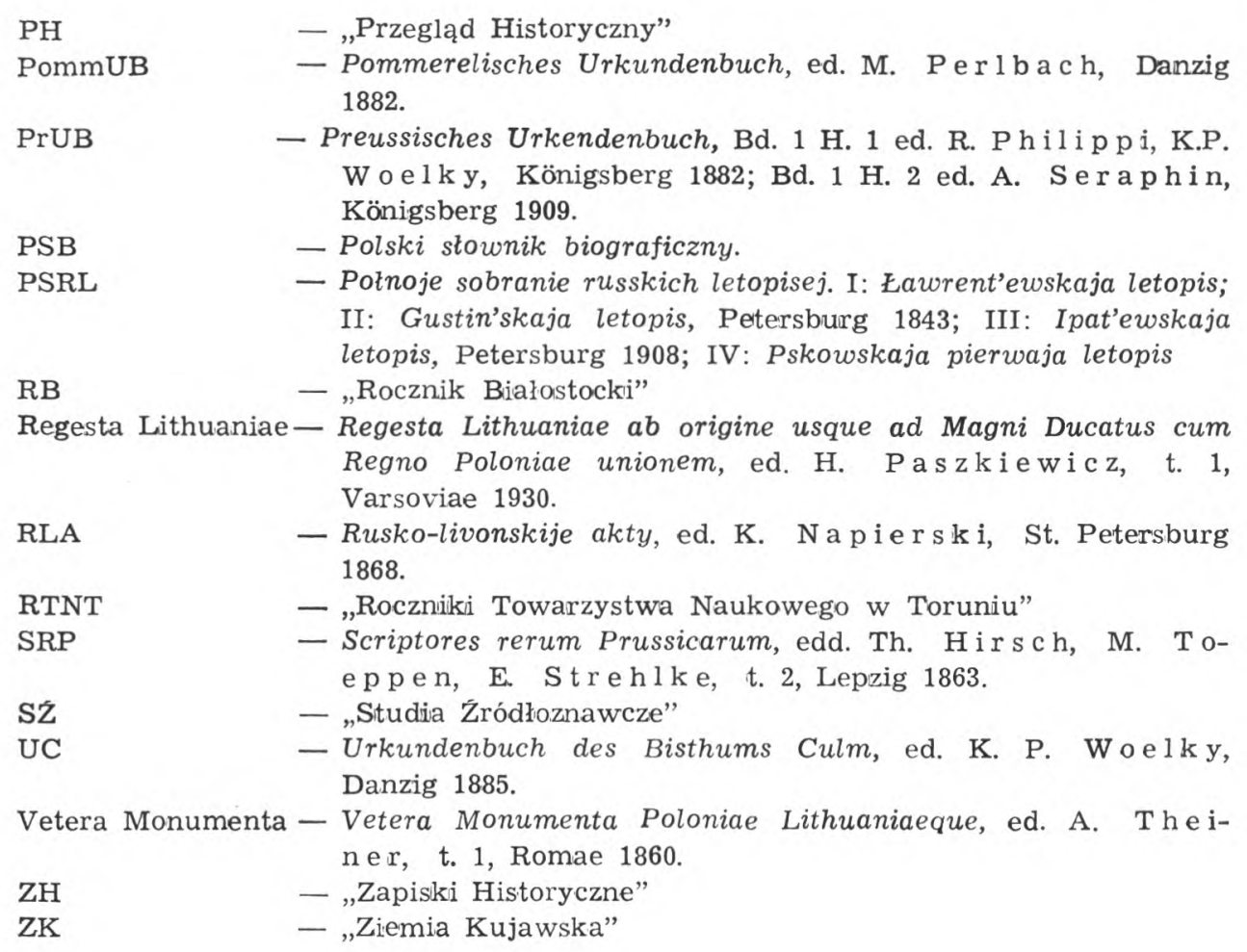

\section{LES TENTATIVES DE CHRISTIANISATION DE LA LITUANIE DANS LES ANNEES 1248-1263}

$R$ és u mé

Face à la proche célébration solennelle du septième centenaire de la constitution de l'organisation ecclésiastique en Lituanie, on ne peut oublier la première tentative de christianisation de ce pays, tentative qui a failli réussir et qui a sii lourdement pasé sur l'attitude ultérieure de la Lituanie à l'égard du christianisme.

Cette tentative fut entreprise au milieu du XIII's. par le premier roi lituanien Mindaugas. Ce sujet fut maintes fois soulevé dans la littérature scientifique polonaise, allemande, russe et lituanienne. Pourtant bien des problèmes irrésolus continuent de frapper les chercheurs qui se penchent sur l'histoire ancienne de l'état lituanien. C'est la personne de Mendogue même qui soulevait le plus de controverses, les motifs de la décision de recevoir le baptême et l'action même de christianisation du pays. On ne peut toujours pas se permettre de juger tous les changements qui s'opéraient alors dans l'état lituanien. La raison de cet état de choses réside dans la médiocrité des sources ainsi que dans le caractère de ces 
sources qui furent entièrement produites hors de la Lituanie et qui s'intéressent faiblement aux problèmes de ce pays. Les renseignements sur cette époque sont toujours fournis par la Chronique de Halicz-Volhynie et la Livländische Reimchronik ainsi que par une poignée de documents dont une partie est constituée par des contrefaçons. Bien que le matériau documentaire n'ait pas été considérablement enrichi, le développement des recherches sur l'histoire de la Lituanie permet l'apprécier de façon toujours différente et plus profonde tous ces problèmes. C'est surtout en plaçant les faits lituanienis dans un contexte plus large des événements politiques dans l'Europe du Moyen Age qu'on peut considérer différemment l'ensemble des problèmes liés avec l'échec de cette première tentative de christianisation de la Lituanie. Cet article essalie de ressembler les recherches précédents, en les complétant, là où c'est possible, par les réflexions personnelles de l'auteur.

Le premier chapitre introduit le lecteur dans les circonstances politiques quii eurent pour résultat la décision de Mendogue de recevoir le baptême par l'intermédiaire de l'Ordre des Chevaliers Teutoniques en Livonie. On y parle surtout de la rivalisation entre Mendogue et son neveu Towtywił pour la domination en Lituanie. Il y est aussi question de la coalition contre Mendogue, de sa dissolution et du triomphe du premier roi lituanien.

Le second chapitre traite des circonstances politiques de la formation du premier évêché lituanien, et s'occupe des relations politico-ecclésiastiques dans l'état lituanien. Il était toujours indubitable que la décision de recevoir le baptême, prise par Mendogue, eut un caractère politique et qu'elle visait à vaincre la coalition ennemie. Il était aussi évident que c'étaient avant tout les Chevaliers Teutoniques des Livonie qui permirent à Mendogue de nouer contact avec le Saint-Siège, qui influençaient les décisions du roi quant à la formation de l'organisation ecclésiastique. C'est à eux qu'on attribue également le mérite d'avoir obtenu l'exemption de l'évêché lituanien qui fut rendu dépendant directement du Saint-Siège, avec l'omission de la métropole de Prusse-Livonie, dont le métropolitain Albert Suerbeer n'appartenait pas aux partisans de l'Ordre. D'ailleurs Mendogue récompensa largement l'Ordre par dons en Samogitie, ce qui est à présent unanimement reconnu. Aussi l'Ordre donna à l'évêché lituanien son premier berger, son prêtre Christian. On savait aussi que Mendogue, bien qu'il ait fait lui-même des démarches en faveur de cette nomination, ne le soutenait guère, ce dont le prêtre se plaignit à la Curie romaine. L'analyse des événements politiques permet de constater une certaine crise dans les relations entre la Lituanie et les Chevaliers Teutoniques déjà dans les années 1254-1255. La victoire sur la coalition ennemie, les larges dons en faveur de l'Ordre, la politique ambiguë de ce dernier mirent en question le sens d'une collaboration étroite du souverain lituanien avec l'Ordre. La dotation désignée par Mendogue à l'évêché lituanien était beaucoup plus modeste que les dons en faveur de l'Ordre. Le pacte signé en automne 1254 à Raciąż entre l'Ordre et Siemowit, prince de Mazovie et Daniel, prince de Halicz-Volhynie, et qui concernait le partage des territoires des Jaćwież, partage auquel prétendait toujours la Lituanie, ce pacte témoigne nettement du refroidissement des relations entre la Lituanie et l'Ordre. Le pacte russio-lituanien à Chełm de la même année semble donc être la conséquence de l'accord à Raciąż. Il est significatif également qu'en 1255 une croisade devait être entreprise contre les Jaćwięg et contre les Lituaniens. Dans ce contexte la plainte de Christian de 1255 sur le manque de soutien de la part de Mendogue devient compréhensible. Les relations entre la Lituanie et l'Ordre s'améliorèrent de nouveau au déclin de l'an 1255 , lorsque l'Ordre reçut de 
Mendogue le don de la Selonie. Jusqu'à présent on doutait de l'existence d'une action de christianisation. Grâce à une nouvelle source sur les questions baltes, trouvée en Irlande, le Descriptiones Ternarum, on peut poser un regard différent sur ce problème. Elle permet de supposer que le roi lituanien avait sa propre vision de christianisation du pays, indépendante de celle de l'Ordre, mais il ne réussit pas à la réaliser. On ne forma donc pas de réseau d'organisation ecclésiastique à cette époque, ni de chapitre. On l'attribue d'ordinaire à la faiblesse de l'état lituanien de ce temps, qui n'était pas encore à même de garantir à l'Église des revenus basés sur un système d'exploitation du peuple vassal. L'état aux formes constitutionmelles faiblement avancées n'était pas capable de répondre à ces exigences sans recourir à la violence, ce qui n'était pas toujours possible à cette étape de l'histoire de Lituanie. La chute de l'évêché lituanien fut l'effet d'une insurrection balte générale contre l'Ordre et du ralliement de Mendogue aux insurgés.

Le troisième chapitre s'occupe de la question de pénétration de la religion orthodoxe en Lituanie au XIII $\mathbf{e}_{S}$, ce qui était favorisé par l'annexion des territoires russes à l'état lituanien. Nous ne savons presque rien sur l'action de christianisation du côte de l'Eglise orthodoxe. Il existe, il est vrai, certains indices de l'intérêt porté par la religion orthodoxe russe à la liquidation du paganisme en Lituanie, mais certainement ces efforts s'arrêtèrent au stade des préparatifs. Le cas de Wojsiełk était isolé et concernait plus la sphère de la vie monacale que de missionnaire.

Le dernier chapitre traite de l'attitude des princes polonais à l'égard de la question de christianisation de la Lituanie au XIII' ${ }^{2}$. Les princes polonais s'intéressaient depuis longtemps aux problèmes baltes et tâchaient de subordonner les peuples prusses voisins. A cause du partage régional de la Pologne, de la brouille entre les princes particuliers cette politique n'était jamais menée avec conséquence. A l'époque en question, c'étaient surtout les deux fils de Konnad de Mazovie qui s'intéressaient aux problèmes baltes: Siemowit, prince de Mazovie et Casimir, prince de Kujawy et Łęczyca, ainsi que le prince de Cracovie Bolesław le Pudique. Ces princes n'agissaient pourtant pas de concert, ils se laissaient influencer par les princes russes qui s'efforçaient avec plus d'énergie à subordomner surtout Jaćwieża. L'ordination du dominicain Wit en évêque lituanien était probablement une tentative de former un évêché lituanien concurrentiel, avec le siège à Łuków, aux confins de la Russie. Cette action était menée par Siemowit et Bolesław le Pudique avec les princes russes en opposition à la politique de Casimir de Kujawy et Łęczyca. C'est le pacte russo-lituanien de la fin de 1254 qui mit fin à cette palitique. La conséquence en fut le renoncement de Wit à l'évêchê en 1255. Les démarches ultérieures des princes polonais avaient plutôt un caractère local et se limitaient aux territoires prusses et de Jaćwięża. Elles échouèrent également, en conséquence de diverses controverses entre les princes.

La date terminale qui clôt ces réflexions est celle de 1263, l'an de la mort de Mendogue, qui termine la première phase de l'ouverture de la Lituamie au christianisme occidental. Bien que ce fut là un épisode, il joua un rôle considérable, surtout dans l'histoire de l'état lituanien. Cette tentative infortunée d'introduire le christianisme découragea les souverains lituaniens de cette religion, causa la montée du conservatisme paien et, par conséquent, retarda le processus d'entrée de la Lituanie parmi les pays civilisés d'Europe et l'exposa au danger qui menaçait son existence. 